

\section{Henry Stommel}

Oceanographer

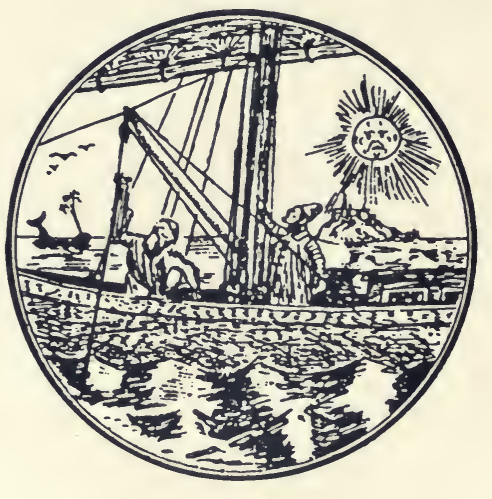

MBL/WHOI

Library

- In Memoriam. 


\section{LIBRARY}

MASSACHUSETTS MARITIME ACADEMY

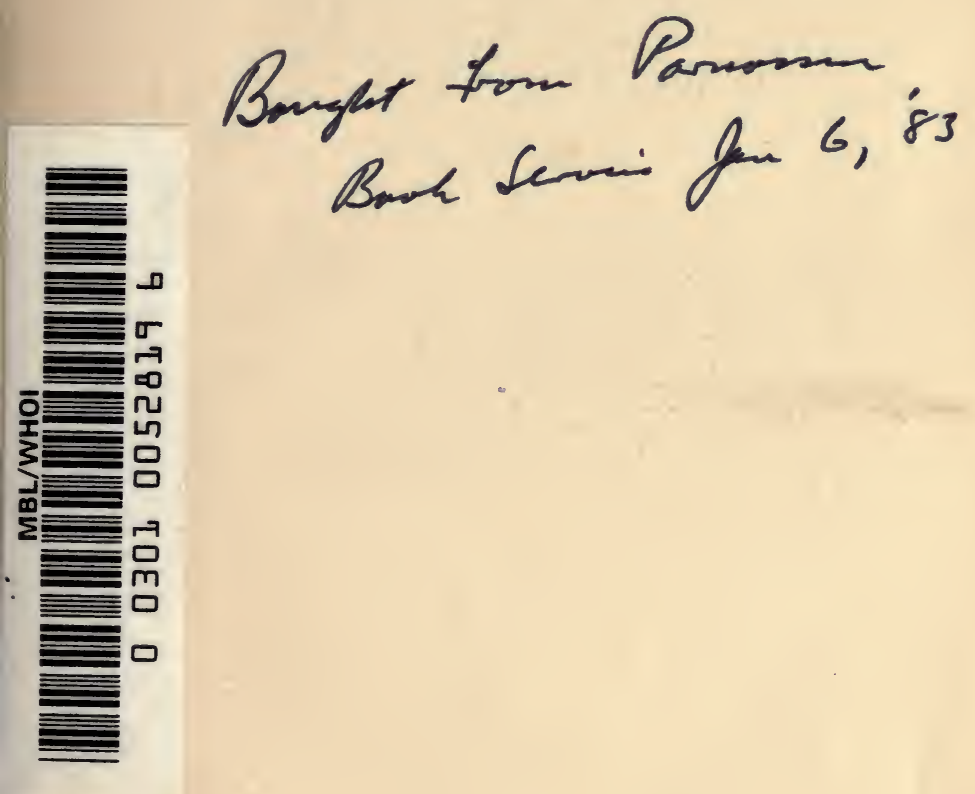






\section{AUTOBIOGRAPHY OF}

CAPTAIN ZACHARY G. LAMSON 

. 


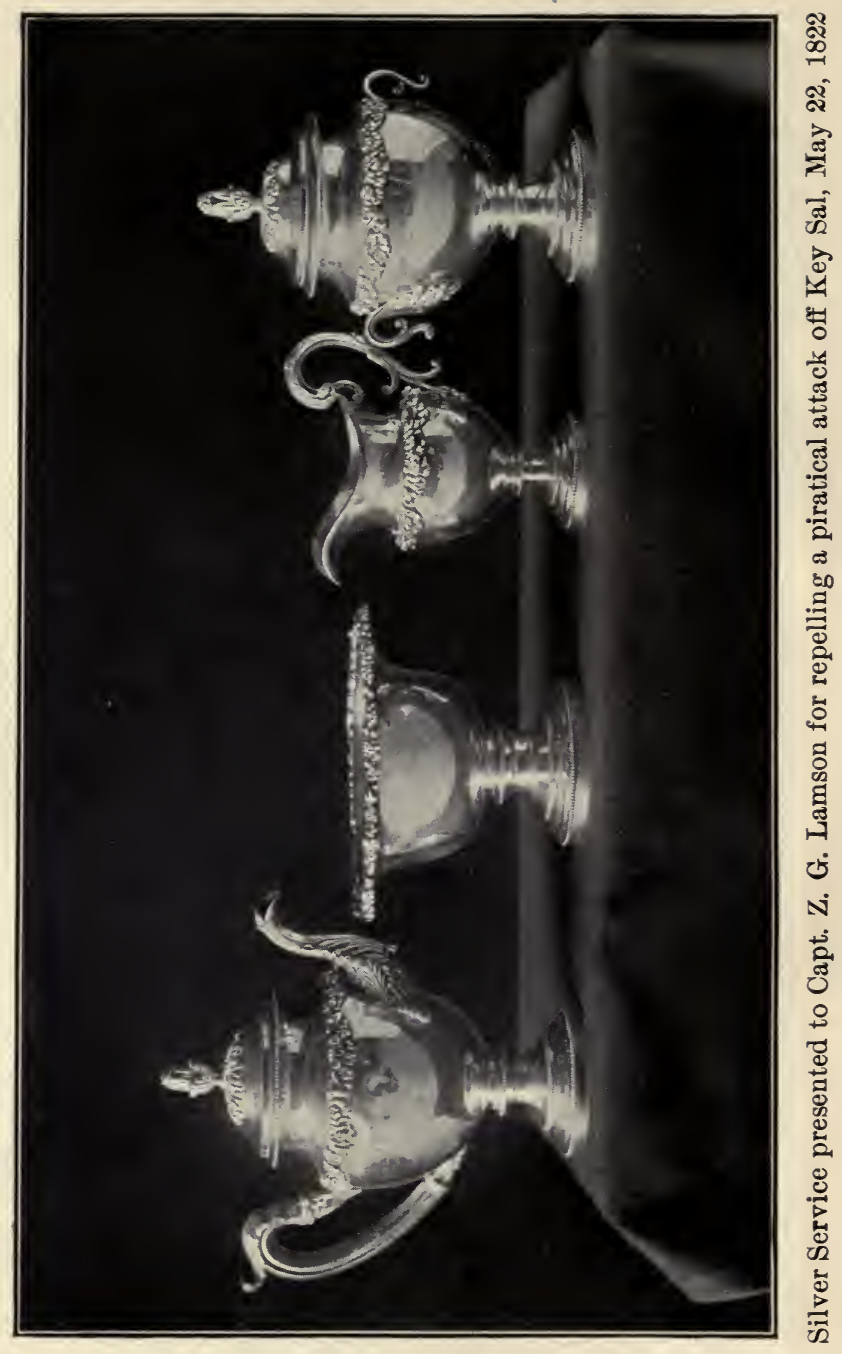




\section{TheAVTOBIOGRAPHYof CantZACHARYG.LAMSON 1797 to 1814 with Jntroduction\& Historical Jotes 6y O.T.HOWE}

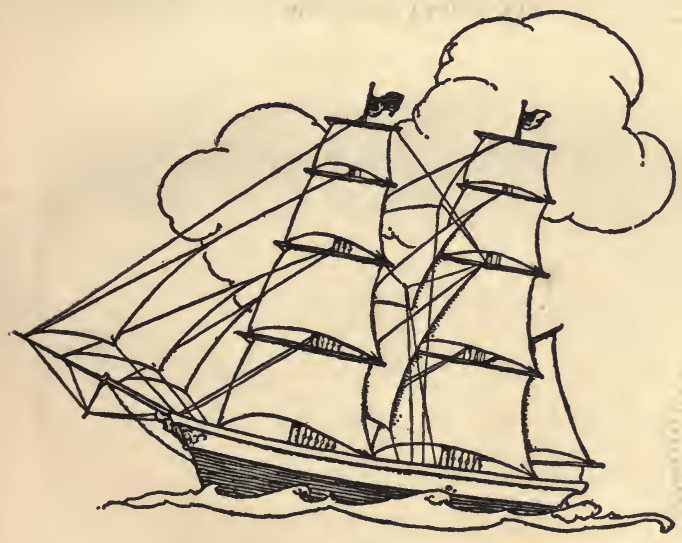

LIBRARY

MASSACHUSETTS MARITIME ACADEMYแIi!

W.B.CLARKE COMPANY 26828 TREMONT STREET BOSTON

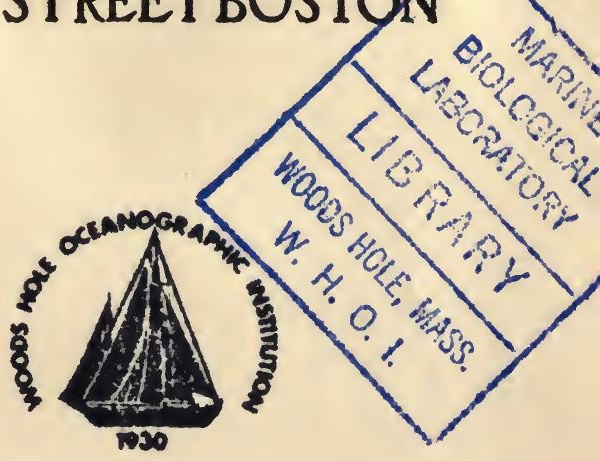


COPYRIGHT, 1908, BY O. T. HOWE

ALI RIGHTS RESERVED

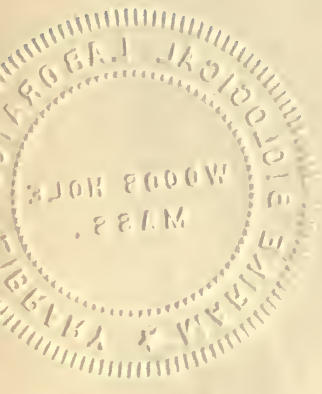




\section{AUTOBIOGRAPHY OF \\ CAPTAIN ZACHARY G. LAMSON}

\section{CHAPTER I}

THE "Diary" of Captain Zachariah 1 Gage Lamson, which forms the motive of this volume, covers the most interesting and romantic period of the commercial history of the United States. It is particularly interesting to the historical student, as it gives a very lively picture of a period which was then, and will probably ever remain, unique in the history of the world. To read his life understandingly one should be thoroughly conversant with the maritime law and history of that period; and as marginal notes hardly give sufficient space, the writer has prefaced the manuscript with an account of the conditions under which in peace or war commerce at that time was carried on.

In the renaissance of American com- 
merce which followed the Revolutionary war the American flag had been carried to all parts of the world. With splendid audacity the merchants of the United States had dared to compete with England for the East India trade, had taken by storm the China trade, had freighted their vessels from the Spice Islands and Africa and pierced the guarded ports of the Mikado. They had passed the Sound to the north and the Straits to the south, showing our flag at St. Petersburg and Constantinople; and most important of all had almost monopolized the large and lucrative traffic of the French and English West India Islands.

But it was not alone from the adventurous skill of her sailors or the restless genius of her merchants that the United States made such remarkable progress, - much was due to the peculiar conditions of the times. The wars of the French Revolution had been succeeded by the continental wars of Napoleon, and the only neutral country in the world which possessed a 
merchant marine and knew how to use it was the United States. This neutrality was of great value to America; but before considering what advantages war gave, it is well to consider under what conditions commerce was carried on in times of peace.

In studying commercial conditions at the beginning of the last century, it is necessary for the student to remember what an important factor colonial trade was in the commerce of that day, and it is impossible for him to understand the intricacies of this trade unless he continually keeps in mind the fact that the colony and the mother country were really one. Granted this fact, there was no more reason why one country should claim the right to trade with the colony of another than to claim the right to share in the coasting trade of that country, which, as is well known, is reserved even to-day by the United States for its own vessels.

The theory of colonial relations was that the colony was to be supplied and defended 
by the mother country and in return exchange its raw material for the manufactured goods of the parent country, carried only in ships of that country. As the colony became more populous and powerful, it was found both impossible and impolitic for the mother country to enforce its rights in their entirety. The natural laws of commerce were not to be ignored, and trade by other powers with its colonies, under certain restrictions, was both permitted and encouraged.

Proximity too had to be considered, and the interests of the colony; for the prosperity of the colony reacted on the mother country, and advantages in the way of trade with other colonies and countries could be obtained by concessions. The result was that trade with the more important colonies of the world was open to vessels of every other country under certain restrictions, and these restrictions were really a concession, as the mother countries claimed, which might theoretically be abrogated 
should the mother country see fit. Practically, however, after trade had been carried on in this way for a term of years, the participants claimed a prescriptive right to the trade, and, while conceding the right to regulate, denied the right to abolish.

The countries of the world possessing sea colonies at this time were naturally the past and present sea powers of Europe, and, as what was gained by the sea could be held only by the sea, the colonial possessions of these powers were all gravitating toward England. Spain, once the colossus of Europe, still held some of the choicest tropical portions of the world, but her empire was beginning to disintegrate, and that it did not all leave her was due to her parasitical dependence on France and later to her alliance with England. At this time she still held the vast territories of Florida, Louisiana $^{1}$ and Mexico in North America, Cuba,

1 By the treaty of San Ildefonso Louisiana was ceded to France Oct. 1, 1800, and April 30, 1803, it was sold to America. 
Porto Rico and some of the smaller West India islands, and all Central America except British Honduras. Though she no longer dominated the Spanish Main, still, with the exception of English, French and Dutch Guiana, and Brazil, all South America was hers, and the trade of this vast section of country reserved for her own subjects.

Portugal, once powerful, was now so weak and inoffensive that there was no pretext to disturb her possessions, which were still vast, comprising Brazil in South America, Goa and Macao in Asia, and Madeira, the Azores, and Cape Verde Islands. Holland, which once contested the sea with England on equal terms, had sunk to the rank of a third-rate power, and had been absorbed by France, but she still held Guiana, Curaçoa, Demerara, Essequibo, the Cape of Good Hope, Java, Borneo and some stations in India.

The richest islands of the West Indies, Guadeloupe and Martinique, belonged to France. Hayti was still hers, with French 
Guiana and some small islands in the Caribbean Sea, but most of them, with the Isles of France and Bourbon in the Indian Ocean, and Pondicherry and Chandernagore in India, were destined soon to be taken from her.

Denmark held St. Martin, St. Thomas and St. John, and Sweden, St. Bartholemew, all small islands in the West Indies, while England, though she had lost her fairest colonial possession, the United States, still held Labrador, Newfoundland, Nova Scotia, New Brunswick and Canada in North America, Jamaica, Trinidad, the Leeward and Windward Islands in the West Indies, Honduras in Central and Guiana in South America, Sierra Leone and the gold coast in Africa, and Ceylon, Bombay and Calcutta in Asia.

In considering the trade of the United States with these colonies, the clearest way to understand the question is to regard all trade with them as prohibited, and see under what conditions it was finally allowed. 
It would be profitless to take up the trade of each country in detail, since the conditions were much alike for all, and as from 1800 to 1812 England was really the power that dictated under what conditions colonial commerce should be carried on, we will take her laws as practically those of the world.

By the English Navigation Act of 1651, no merchandise from Asia, Africa or America could be imported into England in other than ships built and owned in that country, and those ships must be three-quarters manned by English sailors. European merchants might export to England the products of their own country, but must ship such cargoes in the country of their origin. For example, Spain might ship a cargo of wine or olive oil to England in a Spanish ship, but she could not touch at a French port and complete her cargo with French goods. Neither could a Dutch vessel load with Spanish goods for England.

The intention of the Navigation Act was 
first to furnish a numerous and skilled body of sailors available in time of war for the navy, and second to make England an entrepôt of commerce; and in both these aims the Act seems to have been successful. The term entrepôt may be defined as a commercial centre where goods accumulate on their way to market. ${ }^{1}$ Any post which either by its freedom or its geographical position offered a convenient place for vessels to deposit their cargoes and reload with other merchandise was a natural entrepôt.

A place of entrepôt was like a great bonded warehouse where one might take almost everything with a fair chance of sale, and a certainty that one could buy something to take away. The profits to a country possessing such an entrepôt are obvious. All the machinery necessary for the receiving, storing and distributing of merchandise, the employment of labor,

1 Mahan, Influence of Sea Power on the War of 1812, vol. xxi, p. 12. 
wharfage dues, supplies furnished and the thousand things necessitated by a bustling commerce are really a tax laid on such commerce and tend to the growth and wealth of the place of entrepôt. A forced entrepôt is where a country, having the monopoly of certain products, restricts their importation to certain ports and forbids their sale elsewhere.

By the Navigation Act then, trade with the colonies was strictly guarded and the products of the East and West Indies could be freighted only in English ships. But as the American colonies grew in wealth and population, it was found impossible to prevent their trading with their near neighbors, the West Indies, and the navigation laws were modified in their favor. Direct trade between the West Indies and the American colonies was allowed, but limited to vessels of not over seventy tons burden. A direct voyage between the West Indies and England or any other country by colonial vessels was prohibited. When 
the United States became an independent power, she was still hampered by the English Navigation Act, and although Jay's treaty in 1794 obtained for her the right of direct trade with the West Indies, it was coupled with such conditions that she rejected it. The British government, then, by executive order continued the trade of the West Indies with the United States under the same conditions as prevailed in colonial days.

This question of a direct or broken ${ }^{1}$ voyage was of the greatest importance and was afterward one of the causes of the embargo of 1807 and the War of 1812. To repeat, under English executive permission an American vessel of seventy tons burden, or under French law an American vessel of sixty tons burden might carry to the Eng-

1 The term "broken voyage" appears frequently in the commercial history of this period, and means, as the name implies, the interposition of a third port between the place from which the vessel is cleared and the port to which she is really bound. 
lish or French West Indies a cargo of American produce and bring back, say, sugar, coffee or molasses, but she could not sail direct from those islands to any other than an American port. The reason for the limitation of the size of the vessel was to make a voyage to Europe unprofitable, if not hazardous. Once, however, a cargo was landed in a port of the United States and the duty paid, it became American property and could be shipped to any part of the world.

Fortunately for the United States the natural course for vessels sailing from the West Indies to England was to follow the Gulf Stream up the coast and take the short meridian. It was not much of a detour then to land a cargo in Salem or Boston, pay the duties, reload into a larger vessel and complete the voyage to the Continent. This was called breaking the voyage, and cleared the law in $\mathbf{1 8 0 0 .}$

Trade with the Spanish West Indies was at times allowed and occasionally forbid- 
den, but the size of the vessel was not limited. Owing to restrictions imposed, there was very little trade with the Spanish South American colonies. The Danish West Indies were free ports, and the Swedish colony, St. Bartholemew, or St. Barts, as it was usually called, derived its importance from its being open to neutrals in time of war. Although itself a barren rock, the exports of sugar, coffee and molasses from the island were quite large. Vessels could clear from the richer islands to St. Barts and then evade the law by clearing from St. Barts to other ports.

Trade with the East Indies was conducted under the same colonial law as with the West Indies, but there was no limitation as to size of vessel employed. English law allowed a direct voyage between America and the East Indies, but it must not be broken. Trade with the islands of France and Bourbon was free, and much of the French East India trade was carried on from those ports. Trade with the Dutch 
possessions, the Spice Islands and China was subject to comparatively few restrictions.

Such were the conditions of trade in time of peace, but from 1800 to 1812, with the exception of eighteen months, there was no peace. The United States was neutral, but the rest of the world, all that counted commercially, was at war. What rights then did this neutrality give us?

The rights of neutral nations in time of war were determined by international law, and this law was evolved from the customs and precedents of former wars. It could not from its very nature be inflexible, as there were often new conditions to be met, and the way it was construed depended largely on the interests of the party construing it. England believed, justly or unjustly, that she owed her maritime superiority to her navigation laws, and her construction of international law was biased by her determination not to allow those laws to be impaired. In time of peace, as we have shown, 
the United States could trade with the whole world, subject to such local and colonial regulations as each country might impose, and the right to impose such regulations, however burdensome, was not denied. In war, however, where America was neutral, many of these restrictions were removed as the advantage to each belligerent might require, but she was still subject to the disadvantages under which international law placed all neutrals.

What were the rights of neutrals was a disputed question. England, with her supremacy on the sea, naturally took one view and the rest of the world another, but there were some points on which all agreed and these we will first consider.

A vessel owned by a neutral power and carrying a cargo not owned by either belligerent might trade with either belligerent provided she carried no contraband of war. A man-of-war or privateer might stop any neutral vessel to examine her papers, ascertain her destination, and examine for 
contraband of war. If, however, any cause for seizure were found, the vessel must be sent into some port of the belligerents, where she would receive a fair trial in the Admiralty courts.

A blockade of any port or coast must be accompanied by a sufficient naval force to make entry to such port or ports dangerous, and neutrals must be warned previously of such blockade.

On the above points there was no discussion, but on the broad claim that the neutral flag covered neutral goods, that a belligerent had no right to search for contraband or for enemies' goods on a neutral, England placed a firm negative. The failure of the "armed neutrality"1 of 1800 had

1 The "armed neutrality," as it was called, was a maritime confederacy formed by Russia, Sweden, Denmark and Prussia, which attempted to prescribe the conditions under which neutral commerce should be carried on in European wars. The contracting parties agreed to support their construction of maritime law by force of arms if necessary, but the bombardment of Copenhagen by the English put an end to the confederacy. 
settled that question for all the Napoleonic wars. Neither would England allow that a neutral might trade from port to port in a belligerent country, except as a concession by both belligerents.

France, her commerce swept from the seas by the English, unable herself to carry the produce of her colonies in French vessels, modified her colonial laws and offered to neutrals the right, for the war only, to ship direct from colony to mother country. England, however, would not allow this, on the ground that a nation has no right to substitute a neutral fleet of merchantmen to do what, through war, she cannot do herself, and what in time of peace would be denied them.

There were other disputed questions of international law, but these were the most important, and from 1800 to 1805 the United States had little to complain of in her treatment by the belligerent powers.

With the French merchant fleet driven from the sea, and England hampered by 
war insurance and the expense of convoy, American commerce gained rapidly, and was soon second only to that of Great Britain. Coffee and sugar from the French West India islands were shipped in enormous quantities by United States vessels to the United States, and then transhipped and sent on to the continent. This England allowed where the transaction was a bona fide one, that is where the cargo was landed, and duties paid in the United States, but in 1805 British merchants began to complain that the United States was not acting fairly in the matter. Goods from the French West India islands were brought to the States, landed, duties paid and then reshipped on the same vessel, with practically all the duty refunded. In the year 1800, in the case of the "Polly" the High Admiralty Court had decided that this cleared the law, but in 1805 the "Essex," Capt. Orne, took a cargo at Barcelona, landed it at Salem, gave bonds for the payment of duty if the goods were not exported, 
repaired the vessel, reloaded the same cargo, and cleared for Havana. The vessel was seized by the English, and, while it was the case of the "Polly" over again, the judge decided differently. He held that the intention was to be considered, and that as the cargo was never meant for the United States, the mere landing did not break the voyage. This was a severe blow to neutral trade, and at this time there was no neutral trade save with American vessels. ${ }^{1}$

The United States argued that what was right in 1800 could not be wrong in 1805 and that Great Britain had no means of knowing what their intentions were, when they entered a cargo. Whether they sold in the United States or reëxported was a question of price and market, and at any

1 “'Schooner 'Rachel,' Woodbury, arrived in Beverly to-day. Capt. Woodbury remarked that not in his whole voyage, either at sea or in port, had he seen any flag, except the United States." - Salem Gazette, April 1, 1801.

"Not a single merchant vessel under a flag inimical to Great Britain now crosses the equator or traverses the Atlantic ocean."-James StePhens, War in Disguise, p. 68. 
rate the moment a cargo was landed, it became the property of a neutral nation. To this England replied by reaffirming what she called the "Rule of 1756," that a neutral has no right to substitute her vessels to carry on trade for a belligerent, when such trade was forbidden in time of peace. That the fact that she did not enforce the rule from 1800 to 1805 had nothing to do with the question, since to waive a right is not to abandon a principle, and the rule of the Admiralty Court was that all colonial trade is prohibited except as a matter of concession.

There was something to be said for both parties in this controversy. The United States, while keeping to the letter of the law as construed in 1800, did violate its principle. The "Salem Gazette" reports one case where a New Bedford vessel claimed to have landed her cargo, paid duties, reloaded her cargo and cleared for Europe in forty-eight hours. Many vessels carried what was really the property 
of a belligerent, some did not unload, and the intention of most of them was to make practically a direct voyage, but the prescriptive right of five years' trading under these conditions entitled America to at least a proper notice, and to seize her vessels without such notice was a mild form of piracy. The fact was, the British merchants $^{1}$ were jealous of the rapid growth of American trade, and the decisions of the

${ }^{1}$ A London paper of the seventh of August says, "An order, we understand, was sent to all the out ports some days ago, instructing cruisers to detain all American vessels which have on board property not the product of the United States. This order has already been acted on and several vessels stopped. It has been ascertained that the American ships have for a length of time been in the practice of going to the Isle of France, and the French ports in the West Indies, to bring away products which they finally carried into French or Dutch ports. Their usual course was to touch at an American port to give the cargo the appearance of being American property. But it is very well known that such cargoes were never landed. The merchants at Leeds and the rest of Yorkshire have come to a resolution not to ship any goods in a neutral vessel to any port whatever. American ships to American ports excepted." - Columbian Centinel, Sept. 14, 1805. 
English Admiralty courts were always what the political and commercial interests of that country at the moment demanded.

It was possible, however, to break the voyage so as not to conflict with the ruling of the Admiralty Court, but this was but the first of a long series of attacks on neutral rights. Napoleon, unable to invade England or contend with her on the sea, sought to force his continental system on all Europe, and strike at England through her commerce. The exclusion of English goods and English ships from continental ports, if thoroughly done, would, undoubtedly, in time bring England to terms. With this in view, on the first of April, 1806, Napoleon forced Prussia to close her own ports and those of Hanover to British shipping. England replied by a blockade of the coast from the Ems to the Elbe, but promised not to disturb neutral vessels unless coming from or bound to an enemy's port. A few months later, Nov. 21, 1806, Napoleon issued his famous Berlin Decree, 
declaring the British Isles to be in a state of blockade and forbidding commerce with them. No vessel coming from England or her colonies would be received in French ports. This was of course a paper blockade, and contrary to international law. England's reply was Orders in Council of Jan. 180\%. These declared that all ports from which English goods and ships were excluded were also closed to neutrals. This, too, was a paper blockade. Orders in Council of Nov. 11, 1807, somewhat modified this. Neutrals might not trade with any port in Europe not open to the British, but they might trade with such port by going first to an English port, landing and reshipping their cargoes, paying duties, and then going to said port. That is, no trade except through England.

This was promptly answered by the Milan Decree of Napoleon dated Dec. 16,1807 , which was, that "Whatever ship of whatever nation" sailing from a British port, or from countries occupied by the 
British, would count as a good prize to a French war ship or privateer. The situation, then, was this. France controlled most of the continent of Europe. If a neutral vessel cleared for any continental port she stood a good chance to be taken by some British vessel, either on the high seas or when entering port. If to avoid this she entered some English port, landed, and reshipped her cargo, she was liable to be seized by the French.

This situation was an intolerable one, ${ }^{1}$

1 "Extract from a letter of Capt. Williams of the ship 'Friendship':-

$$
\text { 'Palermo, July 12, } 1807 .
$$

'The markets throughout the Mediterranean are glutted with almost everything. A cargo of fish could scarcely be given away. You can hardly form an idea of the difficulties attending neutral trade at this time. We are not allowed either by the English or the French to go from one enemy's port to another. There are thirty sails of Americans at Malta, condemned or under trial. The island swarms with privateers. The English have taken seventeen American ressels laden with oil, several bound to London, but had previously been to enemy's ports. "'Salem Gazette, Sept. 29, 1807. 
as it theoretically put a stop to almost the whole continental trade. But trade did go on under a system most debasing and pernicious to the public morals. The people of France wanted English goods if the government did not, and they got them. England was not inclined to forego French wines and brandies, and she did not. French armies continued to be clothed with English woollens, and the British officers in Portugal drank their accustomed stimulants. Neutral vessels still went from port to port, running great risks, but earning high freights.

That trade was not annihilated was due to several reasons. In the first place the Continental System of Napoleon was unpopular in France, and abhorred throughout the Continent. Smuggling went on to an enormous extent. Neither the decrees of Napoleon nor the British orders in council were at all times rigidly enforced, both sides making what concessions their immediate interests demanded. But it was by the 
license ${ }^{1}$ system that most of the commerce was carried on. Licenses were first used in 1806 and were granted by both the French and English, allowing the ship of a neutral or even a belligerent to enter their ports and discharge a cargo without molestation. The effect of this upon neutrals was deplorable. Licenses were forged, logs falsified, false affidavits.made and bribery freely used. ${ }^{2}$

1 "To such a length did the license system proceed under the Imperial government that it constituted the principal source of the private revenue of Napoleon. And we have the authority of Napoleon himself for the assertion that the treasure thus accumulated amounted at the opening of the Russian war in 1812 to the enormous sum of four hundred million of francs, or $\$ 80,000,000 . "$ Allison, History of Europe, vol. iii, p. 562.

${ }^{2}$ Part of a circular letter read by Mr. Broughmam in the English Parliament.

"Liverpool. Gentlemen. We take the liberty to inform you that we have established ourselves in this town, for the purpose of making simulated papers, which we are enabled to do in a way which will give ample satisfaction to our patrons, understanding all the necessary languages. Of any change that may occur in the different places on the continent, we are careful to have the latest 
The treatment of neutral trade by the belligerents had excited intense indignation in America, and as early as April, 1806, Congress had passed what is called the non-importation bill, in an effort to come to some accommodation with England. This bill, which forbade the importation from Great Britain of numerous articles, was to take effect Nov. 19, 1806, unless in the mean time some satisfactory arrangement with that country should be made. Negotiations between the two countries dragged along, however, and the bill was not actually put in effect until Dec. 14, 1807, eight days before the embargo.

Finding that England would not withdraw her orders in council, or France revoke her decrees, that international law was ignored, and the remonstrances of this

information, not only from our own connections, but also from Mr. J- B-, who has proffered his services and who has for some time past made simulated papers for Messrs. B. \& P. of this town." - Niles Register, vol. 11, p. 166. 
country unheeded, the Congress of the United States on Dec. 22, 1807, passed the Embargo Act. The Embargo was a favorite measure of President Jefferson's, and he was loyally supported in it by the Republican party, which was at this time in the ascendency. It was bitterly opposed by the Federalists, and particularly by those from New England.

They opposed it because they believed the act unjust, unnecessary and not fitted to accomplish the object aimed at. Unjust they thought it, in that it bore heavily on one section of the country and one pursuit. Unnecessary, in that it was still possible to carry on a fairly remunerative commerce under present conditions, with a chance to improve them by negotiations. And not fitted to accomplish the object aimed at, because they knew the dogged obstinacy of the English character, the necessity, to English minds at least, in the struggle in which they were engaged, of acts not otherwise to be defended, and they 
felt sure England could stand the loss of our trade as long as we could stand the loss of all trade. It did not lessen their resentment that the act was passed largely by southern and western votes, for surely men who had travelled and traded, who knew France and England, were better fitted to understand the merits of a commercial measure than a Georgia planter or a Kentucky farmer. Indeed, had the embargo been all that it was not, coming from Jefferson and the Republican party, they would have received it with suspicion; for the Federalists hated Jefferson. Was he not a Jacobin, and had he not strangled the infant navy of the United States, a child of the Federalists, a child whose growth they had hoped to see somewhat commensurate with our commercial increase? And now, at the psychological moment for war, at a time when England was locking arms with her still vigorous opponent, France, the United States were without means of offence save the few frigates 
the Federalists had built, and Jefferson's useless gunboats, and so must resent her injuries, not by war but by a kind of commercial suicide.

The arguments of Mr. Jefferson and his supporters in favor of the embargo were not such as to commend themselves to a commercial community naturally irritated. ${ }^{1}$ There were then as now, a small number of extremely wealthy merchants, and a large number of ambitious, enterprising men doing business on borrowed capital. This latter class, representing nine tenths of the business men of the country, was coolly informed by the President that,

1 (Copied from the National Intelligencer giving what was said to be the views of President Jefferson on the embargo): -

"There are those who suppose the embargo will be productive of incalculable commercial losses. It will certainly produce much inconvenience to the mercantile world, but it will not be unaccompanied by benefits. It will cause the settlement of longstanding accounts. The merchant who has been trading on another's capital may sink, and, is not this just?" - Newburyport Herald, Jan. 1808. 
while the embargo might, and probably would, lead to their failure, it would really benefit the country at large by concentrating business in stronger hands. The village store-keeper, the rich merchant and farmer, the whole creditor class of the country were soothed with the information that the embargo would give them an excellent opportunity to collect old debts and foreclose mortgages. The manufacturing class was congratulated on receiving what was really a prohibitive tariff on foreign goods, which would enable it to extend its business and extract large profits from the community. The rich would undoubtedly become richer, and the poor, poorer, but the satisfaction of those supposed to be benefited by the bill was somewhat dulled by the fact that debts, difficult to collect in time of prosperity, would hardly be collected with greater ease in time of financial distress, nor would creditors be anxious to levy on collaterals which the act itself rendered of little value. 
The intense feeling caused by the embargo had both present and remote consequences. It engendered feelings which did not die when the act was repealed, but remained rankling until the War of 1812, and then produced a crop of disloyalty, which must ever remain a reproach not only to New England, but to the whole coast of the United States.

The embargo from its nature went into force immediately on its passage. No registered vessel of the United States, cleared or uncleared, could leave port. No coasting vessel could leave port without giving a bond of double the value that she would land her cargo in some port of the United States.

News of the embargo reached New England before the bill was actually administered, and many vessels half loaded and some half manned were hurried to sea. Registered vessels, and only those registered could engage in foreign trade, had their registers withdrawn, took a coasting 
license, cleared for some port in the United States and sailed for Europe. Coasting vessels became leaky or ran short of provisions and were obliged to put into some foreign colonial port. Halifax ${ }^{1}$ to the north and Amelia Island ${ }^{2}$ to the south became entrepôts for American produce. Eastport and Passamaquoddy assumed an importance unique in their history, and their beaches for miles were dotted with barrels of flour, en route for Canada and Halifax. ${ }^{3}$ One hundred and fifty thousand barrels

1 "Cleared from the port of Salem, schooner 'Charles,' 'Liberty' and 'Lucy' for Portland. The 'Royal' and 'Good Content' for the Penobscot. The 'Franklin' and 'Four Sisters' for Frenchman's Bay. The 'Enterprise,' 'Cherrystone' and 'Mary' for Portsmouth and twelve more for Machias and other Maine ports. Probably all reached Halifax or Eastport." - Salem Gazette, July 27, 1807.

${ }^{2}$ Mr. Troup, during a speech delivered Feb. 21, 1809, read a letter from St. Mary's, Amelia Island, saying that twenty vessels had lately sailed from the island, laden with cotton and provisions. Twenty more would soon sail and seven ships and two brigs were waiting to load.

${ }^{3}$ Wheeler, History of Castine. 
of flour were shipped to Eastport during the first year of the embargo. ${ }^{1}$ So long as flour could be bought in the United States for five dollars and sold in Canada for twelve and Jamaica for twenty-five dollars a barrel, the embargo was powerless. ${ }^{2}$ Freights were so high that a vessel could afford to forfeit her bond and go abroad to trade.

The "Boston Palladium" of June 24, 1808 , gives a letter from a gentleman in Bristol, England, to an American merchant in Liverpool from which the following is an extract. "There is now here an American schooner of 109 tons, the 'Eliza

1 Cargoes were also landed between West Quoddy and Machias River, within three miles of British territory. The price paid for getting a barrel of flour across the line was twelve and a half cents at first and later rose to three dollars. One man was said to have made $\$ 47$ in one night, running flour across the line. - KeLLY, History of Eastport and Passamaquoddy, p. 144.

${ }^{2}$ In the early days of the embargo two New Haven vessels with flour reached St. Kitts, W. I., and sold their flour at fifty-four dollars a barrel, realizing 550 per cent. - New Haven Hist. Soc. Papers, p. 168. 
and Katy,' without any papers, she having escaped from the embargo. You could charter her for Lisbon or Oporto for $\$ 5500$. Some persons ask as high as five dollars a ton for ships to America. There are only ten Americans here."1 Mr. Lloyd of Massachusetts in a speech ${ }^{2}$ on the embargo stated that two dollars a ton a month was a fair price to pay in ordinary good times. Taking this as a basis, the "Eliza and Katy" would have earned under ordinary conditions some twenty-five hundred dollars a year. A voyage to Lisbon, even if the charter included a return trip, would not have taken three months, so that the vessel would have earned nine times the usual rate.

Much stress was laid by the supporters of the embargo in Congress on the attitude of Mr. William Gray, the great ship-owner

1 One year before the $\mathrm{Naval}$ Chronicle for 1807, p. 86, states: "As a proof of the extensive carrying of the Americans, in the Liverpool papers there are 93 vessels advertised for freight, of which 77 are Americans."

2 Speech of Mr. Lloyd in the United States Senate, Nov. 25, 1808. 
of Salem, who was quoted as saying, that " under the conditions prevailing in Europe, an honest ship master could not carry on his business, and, therefore, the vessels of all honest men had better be tied up at the wharves." It is hinted in the "Salem Gazette" of that day, that certain large shipowners who were in favor of the embargo had many of their vessels abroad and an accumulation of goods in their warehouses, so that they stood to profit by the act both abroad and at home." The "Boston Palladium" of Jan. 13, 1809, expresses the same idea. "The people who were the greatest gainers by the embargo were the great capitalists, who had on hand when the embargo was laid, immense stocks of foreign goods which this unjust system has occasioned to rise. Mr. Smith of Maryland,

1 "Mr. Gray having an immense property in France and countries subject to France is in favor of that policy which will preserve peace with Napoleon, and having a good stock of Indian, Russian, and Italian goods on hand, he is daily growing richer by the embargo." $-N e w b u r y-$ port Herald, Aug. 26, 1808. 
who supported, and still approves the measure, is said to have made four hundred thousand dollars, and Mr. Gray of Salem must have been a great gainer."

Whether Mr. Gray used the words quoted, or whether he gained or lost by the embargo, the writer is ignorant, but it is a fact, as the diary of Capt. Lamson shows, that four days before the Non-importation Bill became operative and twelve days before the embargo, Mr. Gray dispatched the ship "Wells," under Capt. Lamson, with a cargo to Alicante. ${ }^{1}$ It is fair to presume that at this time then Mr. Gray did not feel that an honest man's vessels had better be tied up at the wharf. It is also true that, judging from Capt. Lamson's "Diary," the "Wells," despite her capture by privateers from Algeciras, and the bond for five thousand dollars exacted, made good profits for Mr. Gray during the years 1808 and 1809, and was only ordered

1 "Ship 'Wells,' Lamson, cleared from Salem for Alicante." - Salem Gazette, Dec. 4, 1807. 
home, ${ }^{1}$ when it was evident to Mr. Gray that the repeal of the embargo could not much longer be delayed.

Capt. Mahan ${ }^{2}$ quotes Senator Smith of Maryland as saying," "It has been truly said by an eminent merchant of Salem that, 'Not more than one vessel in eight that sailed for Europe within a short time before the embargo, reached its destination. ${ }^{4}$

1 “'Arrived 'Wells,' Lamson, forty seven days, To William Gray. Dry goods, salt and coals. Passenger, Mr. Story." - Columbian Centinel, June 5, 1809.

${ }^{2}$ Influence of Sea Power on the War of 1812, vol. i, p. 184.

${ }^{3}$ Speech in the United States Senate, Nov. 28, 1808.

4 Niles Register, vol. iii, p. 67. Report by Mr. Monroe.

\begin{tabular}{l|l|l|l|}
\hline \multicolumn{2}{c|}{ By England } & \multicolumn{2}{c}{ By France } \\
\hline $\begin{array}{l}\text { Captures prior to } \\
\text { the British or- }\end{array}$ & & $\begin{array}{c}\text { Captures prior to } \\
\text { Berlin Decree }\end{array}$ & 206 \\
ders in council & & & \\
Nov. 1807 & 528 & & \\
Subsequent & 389 & Captures during ex- & \\
& ecution of Decree & 307 \\
Captures since revo- & \\
cation of Decree & 46 \\
Total & & \\
\hline
\end{tabular}


My own experience has taught me the proof of this, and as a further proof, I have in my hand a list of fifteen vessels which sailed for Europe between Sept. 1st and Dec. 23, 180\%. Three arrived, two were captured by French or Spanish, one was seized at Hamburg and nine were carried into England." This speech of Senator Smith's caused a good deal of discussion in the Salem papers, and the "Gazette" of Aug. 23, 1808, prints a letter from a merchant giving a different story: "Of seventeen vessels which sailed in the month preceding the embargo, nine reached their ports and have returned in safety, one has landed a profitable cargo in England, and of the rest three have been detained by the French or Spanish and have not yet been condemned."

How large a proportion of vessels seized were actually condemned the writer has been unable to ascertain. Of forty cases in the High Admiralty Court on appeal, as reported by Acton, condemnation was af- 
firmed in two thirds, but the proportion of vessels released where no appeal was made must have been much greater. Except when influenced by some state exigency, the decisions were usually fair. The total number of seizures of American vessels by France and England, prior and subsequent to the English orders in council and French decrees, is given by Mr. Monroe in his report as 1475 .

As to the commercial danger of a voyage during the year 1808 something can be learned from insurance statistics. Mr. Pickering of Massachusetts in his speech ${ }^{1}$ on the embargo, in answer to Mr. Giles, states that, taking the records of four insurance companies on 218 risks, the losses amounted to six per cent on the total insurance. The premium on insurance to the West Indies at this time was eleven per cent to go and return ${ }^{2}$ to Sumatra, out and back, four-

${ }^{1}$ Nov. 30, 1808.

2 In 1800 the rate of insurance in Wells, Me., for a voyage to the West Indies and return was four per cent. BodRne, History of Wells, p. 577. 
teen per cent; from Calcutta home, eight per cent; from Europe to the United States, if not violating orders in council, nine or ten per cent, or, insurance against French alone, four per cent. Stephens states in "War in Disguise" that English underwriters were willing to insure neutrals against condemnation for breach of the neutrality laws, for a moderate premium.

At the time of the passage of the Embargo Act, many merchants had, or claimed to have, large amounts of goods abroad, which, they argued, it was only fair they should be allowed to bring to this country. Congress accordingly passed a supplementary act allowing, by especial permission of the President, vessels to go abroad in ballast to bring back such property. Some

Freight and insurance may be reckoned in time of peace as $22 \frac{1}{2}$ per cent. In time of war, 55 per cent. American State Papers, vol. xiv, p. 22.

In 1810 Captain Lamson paid 20 per cent for insurance on his adventure in the ship "Wells" on a voyage to St. Sebastian. - Diary of Z. G. Lamson. 
of the vessels, doubtless, made the voyage in good faith, some did a little trading and returned, and many did not return until the embargo was removed. "Salem Gazette," Jan. 24, 1809: "In consequence of a call of the Senate, Mr. Gallatin has made a statement of the number of vessels 'permitted' to proceed to foreign ports between Dec. 22, 1807, and Sept. 30, 1808, nine months, by which it appears that ' 594 vessels have thus sailed, and, of these, 413 have returned and 137 have not returned. Thirteen were prevented from proceeding. Of these seven were taken by our cruisers and six by the British."”

Mr. Pickering, in the same speech from which I have quoted, states, that 22 vessels sailed from Salem and Beverly, by permission, between April 5, 1808, and Aug. 10, 1808. Of the whole number nine had not been heard from. ${ }^{1 ~ " B u t ~ i t ~ i s ~ n o t ~ k n o w n ~}$ that any have been detained or condemned,

1 The nine not heard from had probably broken parole and were trading abroad. 
and the rest all made their voyages successfully."

The power to grant permits for foreign trade was a dangerous one to put in the hands of one man, but its exercise was limited, its benefits undeniable, and it excited little opposition. The Act of April 25,1808 , however, was so unlimited in its grants, so outrageous in its nature, that even conservative Republicans were shocked and alarmed. By it the President was authorized to detain any vessel bound coastwise, on mere suspicion that she intended to evade the embargo laws. A circular letter ${ }^{1}$ was addressed by the President to

${ }^{1}$ Part of a circular letter from President Jefferson to the governors of several states.

"Washington, May 6, 1808.

. . . "Congress, by the Act of April 25, authorized the absolute detention of all vessels bound coastwise with cargoes exciting suspicion of intention to evade the embargo laws. There being very few towns on the sea-coast that cannot be supplied from their interior country, shipments of flour became suspicious and proper subjects for detention. ... I request of your Excellency, whenever 
the governors of the importing states, calling attention to the law, and asking them to give certificates in favor of any merchant in whom they had confidence, whenever they needed flour or provisions.

It is necessary, writes Jefferson to Gallatin, "to consider every vessel as suspicious which has on board any article of domestic produce in demand at foreign markets, especially provisions."

The power granted by this act was used by the President with unsparing severity. Governors of states were informed by the President that they were too liberal in their permits, cities were told that their supply of flour was sufficient, and if they wanted more it must be for improper purposes, and individuals were refused permits because they were not in sympathy with the embargo. It is not probable that any state

you deem it necessary that your present stock of flour be enlarged, to take the trouble to give your certificate in favor of any merchant in whom you have confidence, for any amount you may deem necessary for consumption." 
or city really suffered for food in consequence of this act, but for many months it was in the power of one man to say whether the inhabitants of certain cities should eat white bread or black, or indeed, whether they should eat any bread at all."

The "Salem Gazette" of Sept. 27, 1808, in an article entitled "Permits," says, " whether Federal or Democrat, we do not know why one man should be permitted to trade with Passamaquoddy in flour and another restrained, or why either should be restrained. We should like to know by what provision of the Constitution the President can do these things." The President, however, by this

1 Memorial from the third ward of the City of New York, Feb. 6, 1809. "The city of New York receives its supplies of provisions and necessities from boats and small craft. Under the Act the collector may refuse, and the President may direct him to refuse, to give the permits necessary for their vessels to move. We suppose New York to be the only city in the world, where under a formal law, the people may be starved at the will of one man." - American State Papers, vol. xiv, p. 745. 
time was in a state of mind where he cared little for the Constitution. His favorite measure, the embargo, had, so far, proved a failure, he believed, through its lax enforcement, and when Congress met in November, he asked, and obtained, as Henry Adams says, 1 " powers practically unlimited, so far as private property was concerned, powers, in comparison with which the alien and sedition laws were narrow and jealous in their grants, powers which placed the fortunes of at least half the community directly under his control."

The Act of Jan. 9, 1809, for the enforcement of the embargo, was most drastic in its nature. No vessel could load without having obtained permission from the Custom House, and her bond that she would not sail without a clearance was increased from twice to six times the value of her cargo. The powers of collectors were made so extensive and inquisitory ${ }^{2}$ that to carry

1 Life of Gallatin.

2 "Freedom of the seas. Yesterday Capt. Farrar of the 
on the coasting trade at all became difficult and humiliating.

The army, navy, and militia of the United States were put at the disposal of collectors of ports and the coast was blockaded from Maine to New Orleans. Vessels that traded in defiance of the law, and some that claimed to be within the law, were seized, tried and condemned, and the prize money shared among their captors as if war existed. ${ }^{1}$ By the middle of February, 1809, the situation had become truly alarming. The numerous petitions sent from towns throughout the country had been ignored by the President, and the new enforcement law was rigidly applied. The leaders of the Federalists in New England made no secret of their intention to resist the law by

schooner 'Betsey' was refused clearance for Passamaquoddy from Salem until he had taken out a barrel of tar, some earthen pots and a barrel of beef. No doubt the collector acts according to orders, but the execution must be painful." - Salem Gazette, July 15, 1808.

1 "Rich cruises. Letter from New Orleans of Aug. 26, from gunboat No. 19, states, that the amount of prize 
force if necessary, ${ }^{1}$ and some among them would have welcomed a dissolution of the Union. Among the common people, however, there was no real feeling of disloyalty. They loved the Union, but, Federalist and Democrat alike, they were disgusted with the embargo and its author. They knew, if Jefferson did not, that the embargo was a failure, and they proposed to stand it no longer. They had refused to submit to foreign tyranny, they had no intention to yield to domestic. Either naturally or by design, their course of resistance was closely modelled after Revolutionary days. Bath, Maine, was the first town to throw down money to each member of the crew, from vessels seized by her for violating the embargo, will be two thousand dollars." - Salem Gazette, Nov. 8, 1808.

1 " The tories of Boston openly threaten insurrection if their importation of flour is stopped. The next post will stop it. I fear your Governor [Sullivan] is not up to the tone of these paracides, and I hope on the first symptom of an open opposition of the law by force, you will fly to the scene and aid in suppressing any commotion." - Part of letter from Jefferson to Gen. Dearborn, Worke, vol. vi, p. 334 . 
the gauntlet, and at a town meeting held Dec. 27, 1808, voted to appoint a committee of safety and correspondence. Two weeks later Gloucester did the same. Boston called a meeting as usual at Faneuil Hall, and four thousand citizens passed a vote, "That we will not voluntarily aid or assist in the enforcement act, and that all those who shall so assist in enforcing upon others the arbitrary and unconstitutional provisions of this act ought to be considered as enemies to the Constitution of the United States and this state, and hostile to the liberties of the people." Some towns went further and in true revolutionary spirit authorized the purchase of arms, ${ }^{1}$ and the

1 "At an adjourned meeting of the best citizens of Newburyport, it was voted, that every subscriber should in ten days, if possible, be provided with a good musket and 24 rounds of ball cartridge, and shall keep the same in a safe and convenient place. It was also resolved, that we do not consider the duty of any soldier to aid in carrying into execution the law of the United States laying an embargo. - Wm. Bartlett. Mod." - New York Evening Post, Jan. 20, 1809. 
enlistment of minute-men. ${ }^{1}$ One incident of the day recalls the Boston tea party. A letter from Boston to the "New York Evening Post" of Jan. 14, 1809, says, "The officers and men of the 'Wasp,' sloop-ofwar, who were put on board the schooner 'Liberty' of Brewster, arrived here last night. On Monday, a party of Indians, forty in number, boarded the 'Liberty,' put the officers and crew on shore and put to sea. These Indians are said to be the descendants of the Aborigines who destroyed the tea in 1774."

The leaders of the Federal party in Boston were skilful politicians, and President Jefferson played into their hands. The "Boston Port Bill" was still recent enough for its name to thrill patriotic hearts, and when on the 2 nd of February the flags of the

1 "A number of the citizens of Hallowell have agreed to arm and equip themselves, and to hold themselves in readiness to march at a moment's warning to defend their rights and liberties." - Newburyport Herald, Feb. $19,1809$. 
shipping in Boston harbor were seen draped in black and at half mast, and the news spread that the port was closed ${ }^{1}$ by order of President Jefferson, the excitement was intense. The second "Boston Port Bill," as it was called, was a trivial affair, except as showing the autocratic power of the administration, but it gave the wily Federalists a chance to make a telling retort on the President by quoting his well-known letter, written from Virginia in 1774, when the news of the "Boston Port Bill" reached him. Jefferson wrote, "If the pulse of the people beat calmly under such an experi-

1 "War Department, Jan. 27, 1809.

"Sir: You will please to consider the instructions heretofore received by you from the Collector or his deputy as inoperative until further orders, the letter from the Deputy Collector to the contrary notwithstanding. And as no vessel can be cleared out of the Port of Boston or Charlestown before a Collector shall be appointed, you will endeavor to prevent any vessel departing from that harbor contrary to law. Your obt. servant,

“H. Dearborn.

"Col. John P. Boyd." 
ment by the new and, 'till now, unheard of executive power of a British Parliament, another and another will be tried until the measure of despotism be filled up." Fortunately for the United States and New England, the parallelism between embargo and revolutionary days was not completed by a Boston massacre. For several weeks, however, the Federal authorities were set at defiance, vessels were armed ${ }^{1}$ to resist the law, and it only needed a little more audacity on one side, or a little less restraint $^{2}$ on the other, to precipitate a con-

1 The brig "Mary Jane," 156 tons, belonging to a Bath firm, was armed and loaded for the West Indies. No attempt was made to conceal her intention to run the embargo, and the United States cutter was waiting for her. She cleared for no port, ran down the river exchanging broadsides with the government vessel, sustained the fire of the fort at the mouth of the river and put to sea. Parker McCobb Read, History of Bath.

2 "Letter from Providence. We are under martial law. The Governor has called out four military companies to protect the embargo. The companies met and decided to return to their homes. The streets were thronged and had a shot been fired, the whole military force would have 
flict which might have changed the whole history of the American Republic.

Outside of New England the feeling was much the same though there was no such organized opposition. At St. Albans, Vermont, resolutions were adopted, one of which reads, "Any citizen who shall express approbation of the present measures of the Federal Government relative to the embargo, is considered an enemy to our common country." The Augusta County, Virginia, freeholders resolved, "If the embargo is not removed, it will produce the downfall of the community, bankruptcy, and civil war." The "Baltimore Sun" boldly stated that the civil compact had been violated and dissolved, and, it goes on, "A law which is to be enforced at the point of the bayonet will bring on a struggle, which may terminate in the overthrow of the Government."

Personal suffering, too, by 1809 , in the been massacred." - New York Evening Post, Jan. 27, 1809. 
seaport towns had become pronounced. Sailors, as a class, are not provident, and when we consider that just before the embargo, the United States owned 1,200,000 tons of shipping, manned by eighty thousand sailors, it is evident it could not be otherwise. Part of our seamen were employed on American vessels abroad, and part in coasting and fishing, but the crews that should have manned two thirds of the American marine were idle or serving on British vessels. ${ }^{1}$ One of the jokes of that day on the embargo - and the papers are full of them - refers to the emigration to Canada: "Where are you going, Jack? To Halifax, by gum, I can't stand this dam'bargo any longer." Those of the sailors who remained at home, and the small tradesmen and mechanics, suffered, and suffered severely.

1 “"The British packet 'Prince Adolphus' sailed from New York last Saturday for Falmouth, England. Her decks were crowded with seamen going to England to seek employment." - New York Herald, March 22, 1808. 
In and around Portland, Maine, thirty firms failed the first year of the embargo, and by 1809 the market house was turned into a soup kitchen, and long lines of soup kettles provided daily nourishment for hundreds of the poor. ${ }^{1}$ New Haven ${ }^{2}$ and other towns adopted the same device, and according to the "Salem Gazette" of Feb. 7,1809 , "Twelve hundred persons in this town, about one ninth of the population, depend for their daily subsistence on the soup establishments lately instituted. If to these be added those supported by private charities, it will probably be found, that one fifth of the inhabitants of this industrious, enterprising and wealthy town of Salem are supported by alms." Marblehead was no better off. "Her fishermen were idle, eighty-seven fishing smacks rotting at her wharves, and the $\$ 2000$ appropriated by the town for the suffering, insufficient to give relief."'3 Even under these conditions,

1 Portland in the Past, p. 426.

2 New Haven Hist. Soc. Papers, p. 168.

3 Rhodes, History of Marblehead, p. 231. 
Marblehead, the most democratic of Massachusetts towns, kept steadfast to her faith, and cheered the heart of Mr. Jefferson by her resolution of Dec. 7, 1808, endorsing the embargo and offering her fishing fleet ${ }^{1}$ to the National Government to help enforce the law.

Outside of New England and the middle states, financial loss, though perhaps not personal suffering, was greater than in the more frugal and wealthy northern states. The planters of Virginia, always in

${ }^{1}$ It was hoped that the Government would employ sufficient of the fishing fleet to afford work to her idle seamen, but so far as the writer can ascertain, but one vessel was thus employed.

"One of the Marblehead fishing fleet is now fitted out as a Guarda Costa and is ready to cruise to watch the ports of Beverly, Manchester, Gloucester and all along shore. She carries six guns and thirty-one men and is commanded by Capt. Lindsay." - Boston Gazette, Feb. 20, 1809.

"Gloucester, Feb. 22, 1809. The following armed fleet is now in the harbor. Gunboat No. 47, Nicholson. Gunboat No. 57, Esken. Cutter, 'Mary Babson,' and the Marblehead Guarda Costa 'Dido.' " Boston Gazette, March 2, 1809. 
debt, were ruined by the embargo. In North and South Carolina the price of produce fell one half, and the merchants and planters were threatened by debts and executions. Rice, which before the embargo sold freely at $\$ 3.50$, fell to $\$ 1.75$, cotton from thirty-four to twenty-two cents a pound. ${ }^{1}$ Owing to the difficulty of shipping provisions, the price varied greatly in different sections of the country. While flour in Fredericksburg sold at two dollars a barrel, in Massachusetts it brought six to eight. ${ }^{2}$ Hay fell from fifteen to seven dollars a ton. ${ }^{3}$

Along the frontier and on the seaboard, cotton and provisions were higher because of the enormous amount smuggled, and

${ }^{1}$ Ramsey, History of South Carolina, p. 39. Charleston Courier, Feb. 1808.

Washington, North Carolina, "Effects of the Embargo." "In a neighboring county were sold 1000 acres of land for twelve dollars. Four grown negroes, three horses and three beds brought ninedollars." - New York Evening Post, Dec. 8, 1808.

${ }^{2}$ New York Herald, July 19, 1808.

${ }^{3}$ History of Newcastle. 
it was to these evasions of the law that Mr. Jefferson laid the failure of the embargo. Had it not been for the evasions, however, the law would not have lasted six months. The illicit traffic across the frontier, north and south, the numerous vessels driven by stress of weather into Halifax and the West Indies, the sixty vessels a month allowed to sail by executive permission, served as a safety valve, and helped postpone the inevitable ebullition of popular wrath:

The passage of the Enforcement Bill of Jan. 9, 1809, was the doom of the embargo. On Feb. 29, to the secret disappointment of a few Federalists, and the great joy of the American people, the embargo was repealed.

Mr. Jefferson is said to have believed to his death that the embargo was a wise measure. ${ }^{1} \mathrm{He}$ was, to his credit be it

1 Jefferson writes from Monticello in 1810 to Mr. Pinkney in reference to the embargo. "Thus we were driven from the wise and high ground we had taken, and 
spoken, opposed to war; ${ }^{1}$ but it was not to his credit that he used his influence to keep the United States in a condition where she could neither fight nor negotiate with success. A tithe of the money lost to the country by the embargo, even the two millions wasted by Jefferson on his gunboats, ${ }^{2}$ would have doubled the strength of the United States Navy, and enabled us to obtain respect abroad. War there need not have been, for England, at this time, could not afford to fight, but as long as we confined ourselves to lucid expositions of rights and irritating recriminations for wrongs, England would pay no attention to us.

which, had it been held, would either have restored us free trade or established manufactures." - Mass. Hist. Collections, Jefferson Papers.

1 Extract from a letter of Jefferson's to Sir John Sinclair. Philadelphia, March 23, 1798, "War is an instrument entirely inefficient toward reducing wrongs, and it multiplies instead of indemnifying losses."

2 These gunboats were authorized in 1806. Two years later Paul Hamilton reported that $\mathbf{1 7 6}$ had been constructed at a cost of $\$ 1,760,000$. 
As to France, and by France we mean Napoleon, her conduct toward the United States was as much worse than that of England as a stab in the back is worse than a blow in the face.

It is of interest to consider what trade was open to the United States at a time when Congress passed the embargo. In the "Columbian Centinel" of Nov. 26, 1808, is Gallatin's report of exports to ports free from British orders in council, by which it appears that the sum total of such exports was $\$ 60,250,486$, of which $\$ 36,109,999$ were domestic and $\$ 24,140,487$ were foreign. The trade with England and her colonies was still open, as well as that with the French, Spanish, Dutch and Danish Islands, and with India, China, Asia Minor and Sweden. Mr. Pickering, in his speech of Nov. 30, 1808, states that Mr. Gray of Salem, and Mr. Thorndike ${ }^{1}$ of Beverly,

${ }^{1}$ Quotations from a letter to Mr. Pickering from Israel Thorndike: "But of the fact I have no doubt, that our trade would be much greater if the embargo was removed, 
both prominent merchants, in private conversation had expressed their belief that the trade open to the United States free from British orders in council at the time of the embargo, was as large as the normal trade in time of peace for the same period.

There is no question, too, but that many of the seizures of American vessels by the belligerents were such as a neutral nation had no right to resent. If a merchant tried to run the blockade at a port legitimately guarded, or introduced colonial goods in a cargo ostensibly domestic, ${ }^{1}$ he had no right

than it can be in time of peace. Our exports, if embargo was removed, would be $\$ 66,250,000$. If peace was to take place, and the European nations resume their trade, we should export $\$ 54,699,000$."

${ }^{1}$ A little more care on the part of American exporters would have saved much trouble and expense. "Admirality Court of Sept. 29, Sir William Scott. Case of the 'Minerva,' Caldwell, Master. Vessel from New York to Amsterdam. Only question was on some hides brought by another vessel from Central America, and put on the 'Minerva' without landing. Court held it was not a bona fide importation and confiscated the hides but restored the ship and the rest of the cargo." - Salem Gazette, Nov. 20, 1807. 
to complain if his vessel was seized. The fact was, that the merchants of the United States played a sharp game, and were as unscrupulous in regard to belligerent rights as England and France were in regard to neutral rights.

On April 17, 1808, those American vessels which had been abroad when the embargo was passed, as well as those which had escaped from the United States during the embargo, received from the French Emperor ${ }^{1}$ one of his characteristic blows

1 From 1807 to 1812 the duplicity shown by Napoleon in his treatment of American commerce was simply astounding. At the very moment he was meditating some act of confiscation of American vessels, his expressions of friendship for the country would be most profound. Even his own ministers, not easily abashed, were at times mortified and disgusted with his measures. Mr. Serurier in a letter to Mr. Monroe under date of July 20, 1811, writes, "The introduction of tobacco is not prohibited in France. It forms the first object of culture of some of the States of the Union, and his Majesty having an equal interest in the prosperity of all, desires that the relations of commerce should be common to all parts of the Federal territory." This was written within a few days of the confiscation of large amounts of American tobacco. 
through the Bayonne Decree, ordering sequestration of all American vessels in French ports, as being under suspicion of having come from England. They must come from England, was his plea, as the embargo forbids their coming from the United States.

The embargo was repealed Feb. 29, 1809, to take effect March 15, and a Non-intercourse Bill substituted. Under this act French and English vessels were excluded from our ports, and importations from those countries were forbidden. ${ }^{1}$ American vessels sailing from our ports were under

${ }^{1}$ Evasions of the Non-intercourse Act were carried on systematically. One curious instance of this is given in the History of Eastport and Passamaquoddy, p. 156. Under the law plaster of paris could not be imported into the States from the Provinces. A cargo would be run into Eastport, and the owner would go to the Custom House and inform against himself. The cargo would be seized, confiscated and sold at auction. There would be no opposition and the cargo would be bid in by the owner for a trifle. Half the sum realized would be returned to the owner, under the law for informing. The cargo was now American property and could be shipped anywhere. 
bonds not to engage in the trade or enter the ports of either nation. In case, however, either France or England should withdraw their decrees or orders in council in such form as to satisfy the President of the United States, then he, by proclamation, might open trade with the one or both so doing.

Mr. Jefferson retired from office before the repeal of the embargo actually went into effect, carrying with him as a valedictory the remark of John Randolph, that, "Never has there been an administration which went out of office and left the nation in a state so deplorable and calamitous as this." And now, the Federalists, with the taste of the embargo still bitter, and the flavor of the Non-intercourse Bill not satisfying, drank the toast, "Mr. Madison, may he immediately after receiving the mantle of Mr. Jefferson, be struck with a perpetual embargo, hauled up in a dry dock and dis-mantled."

Soon after the passage of the Non-inter- 
course Act, Mr. Erskine, the British minister at Washington, made representations to the government that the British ministry were prepared to withdraw their Orders in Council of Jan. 7 and Nov. 1, so far as they affected the United States, provided the President would release England from the application of the Non-intercourse Act, as he was authorized to do in the bill.

In this offer Mr. Erskine exceeded his instructions, or, rather, suppressed the conditions on which he was authorized to make such an arrangement. Mr. Madison, pleased to begin his administration in so satisfactory a manner, promptly consented, and on April 19, 1809, issued a proclamation announcing that trade might be resumed with England on June 10, the date fixed for the withdrawal of the orders in council. Mr. Erskine's action was promptly disavowed by Mr. Canning for the British government, and Aug. 11, the Non-intercourse Bill was again put in force against England. 
On the 26th of April, 1809, Great Britain revoked her Orders in Council of Nov. 1, 1807 , and substituted a blockade of the coasts of Holland, France and that part of Italy actually occupied by the French. This blockade was supposed to be a real one, and neutral vessels were no longer compelled to go first to England, but the trade in licenses and simulated papers went on as merrily as ever. The limitation of the blockade, however, was, on the whole, helpful to American trade, which now began to revive, ${ }^{1}$ but which, as Mahan says, "did not again, before the war regain the fair proportions of the year preceding the Embargo."

Although 1807 was undoubtedly the banner year for American commerce, so far as

1 "Cleared from the port of Salem, from March 16, to April 15. To Canton 1 ship, 1 brig. Sumatra, 6 ships, 1 bark, 1 brig. Gottenberg, 2 ships, 5 brigs, 1 schooner. Rio Janeiro, Sardinia, Sicily, Tangiers, Azores, Fayal, Portugal, St. Barts, Havanna, La Guayra sixty vessels manned by 574 sea-men." - Salem Gazette, April 13, 1809. 
exports and profits were concerned, still examination of statistics shows the difference between that year and 1810 was not as great as it seems. On the face of the figures shown, the difference is enormous. Our exports for 1807 were in round numbers $\$ 108,000,000$, and for $1810, \$ 66,000,000$, a difference of $\$ 42,000,000$ in favor of 1807.1 But our domestic exports for 1807 were $\$ 48,000,000$, and for $1810, \$ 42,000,000$, a difference of only six million, and even this difference might disappear had prices been the same in the two years.

The fact is, domestic exports were larger in 1810 , but the price received for them was less. ${ }^{2}$ We exported in 1810, 27,000,000 more pounds of cotton, but the price had fallen from twenty-two to fifteen cents a pound. We exported forty thousand more tierces of rice in 1810, but the price was twenty-five dollars a tierce in 1807, and twenty dollars

1 Pitkin, Commerce of America, p. 275.

${ }^{2}$ Pitkin, Commerce of America, Niles Register, vol. 11, p. 315. 
in 1810. Our exports of tobacco were twenty thousand hogsheads more in 1810 , but we received twenty dollars a hogshead less. Flour was an exception, being fifty cents a barrel more in 1810 .

Now it was the domestic exports that really constituted the trade of the United States for the two years. The mere fact that twenty or thirty million dollars' worth of sugar and coffee was landed in our ports, and then transhipped to the Continent, is not such a great factor. Of course, there was the profit of entrepôt, but the great object was to get the vessels out of the United States as soon as possible, and, had it been allowed, these cargoes of sugar and coffee would never have been landed in the United States, and never have figured as exports or imports.

If, however, the loss of thirty-five million dollars' worth of foreign exports in 1810, as compared with 1807 , meant a loss to the carrying trade of the United States in proportion, then, indeed, the loss would be a 
serious one. But the fact is, the whole tonnage of the United States in 1807 was $1,197,333$, and in $1810,1,389,715$; that is, nearly two hundred thousand more tons in 1810 than in 1807. The tonnage built in 1806 was 126,393 , and in $1810,127,575 .{ }^{1}$ Now it is fair to say, that the merchants of the United States would not have increased their tonnage unless there was work for it to do, and whether that work was carrying coffee and sugar on a broken voyage to Europe, or trading in some foreign country, so long as the vessels were busy, made little difference. The year 1811 makes as good showing as 1810 , and these facts are interesting as showing that there still remained to the United States a large and lucrative commerce when the War of 1812 was declared.

The Non-intercourse Act, like the embargo, was a failure, and May 1, 1810, the act was repealed and another substituted, which gave the President the power, in case either France or England should rescind

${ }^{1}$ Pitkin, Commerce of America, p. 430. 
their obnoxious decrees or orders in council, to make proclamation to that effect, and if within three months the other nation did not follow its example, then those sections of the Non-intercourse Act which forbade importation from or trade with the country so refusing should again be put in force.

About the same time, March 23, 1810, Napoleon pronounced the "Rambouillet Decree," not published, however, until May 14, confiscating any "American ship or its cargo which was in or might enter any port of France, her colonies, or any territory in possession of French troops." Under this decree, ships and cargoes to the amount of ten million dollars were seized in France, Spain, Italy and Holland. It is probable that some of these so-called American ships were English with simulated papers. ${ }^{1}$

The President, by proclamation, Nov. 2,

1 "It is an undoubted fact, and one well known to the trade, that most of the English ships that have gone to the north of Europe for the past two years, have taken the American flag and simulated papers. These adven- 
1810, announced that France had revoked the decrees of Berlin and Milan, and that unless Great Britain withdrew her orders in council, violating neutral rights, by Feb. 2, 1811, the Non-intercourse Act would be enforced against her. As a fact, Napoleon, with his characteristic shrewdness and duplicity, had not formally revoked the Berlin and Milan decrees, but the American government was prepared to believe that he had practically done so, and called on England to fulfil the promise she had often made that when France revoked her decrees she would withdraw the orders in question.

Great Britain refused to consider the action of Napoleon as a revocation of the decrees, and consequently declined to withdraw the orders as requested. The result was, that Congress passed, Feb. 28, 1811, a new bill, first repealing the Non-intercourse Act, and then reviving it against England

tures were commenced and concluded by English merchants in England." - Extract from a London paper, Niles Register, vol. 1, p. 135. 
only. Thus the last blow in the warfare against commerce was given by the United States government itself, and American vessels that had left England without knowledge of the new act, found, on their arrival in this country, that they were prohibited from landing their cargoes, except under heavy penalties. Still harder was the fate of vessels from British India. ${ }^{1}$ They had been put under bonds in India not to land their cargoes anywhere except in the United States. If they landed them in the United States, they must pay a heavy penalty; if they landed them anywhere else, they forfeited the bond given in India. The United States finally remitted most of these penalties, but only after a long delay.

On the fourth of April, 1812, Congress laid an embargo on American shipping for ninety days, preparatory to war. War could bring no worse fate to the American Marine, and June 18, 1812, war was declared.

${ }^{1}$ Pitkin, American Commerce, p. 211. 


\section{CHAPTER II}

T $N$ the sketch the writer has given of the 1 warfare against commerce which preceded the War of 1812, nothing has been said on the subject of impressment, for, while the impressment of American seamen had much to do with bringing on the war, it had no direct effect on commerce. Indirectly, however, it did affect commerce, in that it stimulated bad feeling between our country and England, and caused many of our citizens to favor measures of commercial restriction and retaliation which otherwise would have lacked their support. Indeed, one of the last arguments of a supporter of the embargo if pushed hard in debate was: we must do something to show England that she cannot impress our seamen with impunity.

This feeling of indignation against im- 
pressment was both honorable and patriotic, and it is to the credit of President Jefferson that through his stormy and unfortunate term of service he never wavered in the position he had taken, that the rights of American seamen on the ocean must be respected. If, however, this could not be accomplished by negotiation, President Jefferson was prepared to sacrifice commerce and have the people of the United States live the simple life of an agricultural community, ${ }^{1}$ an idea which, however pleasant to a rich planter or farmer, hardly commended itself to the inhabitants of sterile New England.

There was in the question of impress-

1 "Perhaps to remove as much as possible the occasion of making war, it might be better for us to abandon the ocean altogether, that being the element whereon we shall be exposed to jostle with other nations. This would make us invulnerable to Europe by offering none of our property to their prize, and would turn all our citizens to the cultivation of the soil. It might be time enough to seek employment for them as seamen, when the land no longer offers it." - JEFFERSON, Notes on Virginia, vol. iv, p. 20. 
ment by England of American sailors, two sides, as is usual, but what is not usual, there was no compromise between them, no middle ground on which both could unite. Either England had to renounce what she believed to be an inherent right, strengthened by precedent, or America must be false to her principles, and sacrifice what she claimed were the rights of man.

England, from a time which ran far back in her history, had claimed the right to retain the allegiance of her subjects, even when they had shown themselves forgetful or unwilling, and had wandered to a foreign country. In time of peace she might not care to enforce this right, but when war came she insisted on her right to reclaim her subjects, whenever or wherever she found them on the high seas.

Of her right to reclaim them from a ship in an English port, there was no question. This claim of England's that a native-born citizen has no right to expatriate himself, was not peculiar to that country or time. 
Allegiance carries with it reciprocal rights and duties, and a man who has enjoyed his country's protection has no right in time of necessity to refuse his aid. Even in America there were many. who believed England right in her contention, the only question being how those rights should be enforced.

Certainly no self-respecting nation could allow a foreign power to reclaim seamen within her own territorial limits, nor did England ask this; but, on the high seas, where no country held jurisdiction, England claimed the right to search for, and impress, her seamen whenever she found them. Her navy meant so much to herand without seamen the navy was useless - that the right of impressment was deeply ingrained in every English heart, and, like the press gang in their native ports, seemed an unpleasant but necessary evil. So long as this claim was enforced against nations whose own seamen in appearance and language were easily distinguishable from the English, there was not much chance for 
injustice; but when the United States became a nation, the seamen of the two powers could not easily be told apart.

This, which to an American seemed a strong argument against the practice, was to the Englishman an added reason for enforcing it. There was little danger that the British sailor would seek the ships of any of the continental powers; as a rule, he hated foreigners; but on an American vessel he found himself among men of his own race and language, and as the temptation was greater, so was the need of combating it.

The United States made the broad claim that the flag should cover the men, that an American ship meant American sailors, and, except in their own ports, the English had no right to investigate. A vessel of the English navy in time of war might under international law stop an American vessel on the high seas and examine her for contraband of war, and, if she saw cause, order her into an English port for adjudication; but this did not condemn the vessel or cargo. 
The seizure must be followed by a fair trial, where evidence could be produced on both sides; and if the capture was declared illegal, damages could be demanded. But with an impressed seaman, whose personal liberty should be worth more than mere property, there was no such investigation. The British officer had the crew mustered on the quarter-deck and picked out those whom he believed, or professed to believe, English. Had he been honest, he must at times have made a mistake; but, as a matter of fact, he too often picked out the best men irrespective of nationality. Many of the men thus impressed had certificates of American naturalization or protection; but the English pointed out, with truth, that these certificates could be procured by any English sailor from an American consul for a dollar or two, and were in fact a matter of barter among the sailors.

Strange to say, the feeling in the United States against impressment was strongest in that section of the country where its evils 
were least felt. One third of the shipping, ${ }^{1}$ and presumably one third of the sailors of the United States, belonged to Massachusetts, and yet a large minority of the citizens of that state were inclined to condone, if not justify, England's course. One reason for this was, undoubtedly, the desire to avoid friction with England and disturbance of trade. Many, too, believed that England was really right in her contention, and that, as a matter of policy, it was better for the United States that her ships should be manned by American seamen and that English sailors should not be encouraged to sail under our flag. That there were thousands of such native-born Englishmen serving on American vessels was acknowledged by every one.

Mr. Gray of Salem, at a time when he was not in sympathy with the Federal party, in evidence before a committee of

1 " Tonnage of the United States for the year 1807 amounted to $1,200,000$ tons, of which one third belonged to Massachusetts." - Boston Gazette, Jan. 11, 1808. 
the Massachusetts House of Representatives, ${ }^{1}$ stated, that, in his opinion, five per cent of the men serving on American vessels were native-born Englishmen. ${ }^{2}$ Higher pay, better food, less rigid discipline and the desire to avoid the dangers of war depleted the crews of English vessels, and brought the deserters to the American service.

That England should wish to reclaim these men was natural; that, having the power, she should insist on doing so was inevitable. How it was done, with what consideration and justice the force was administered, depended on the character of the English officers in command. The actual investigation was considered too trifling a circumstance to demand the presence of an English captain, and his lieuten-

${ }^{1}$ Report of the Committee of the House of Representatives of Massachusetts, 1813, p. 43.

2 "Three quarters of the sailors serving on vessels owned in Southern ports of the United States, were said to be Englishmen." - Mr. Madison's War. 
ant was usually sent to represent him. The subordinate was probably told to take only native-born Englishmen; but, if the ship was short of hands, he was also told not to come back empty-handed. The result of such an examination was inevitable. The lieutenant found the desired Englishman; some poor American sailor was tied for an indefinite period to a life he dreaded and despised, and the American vessel sailed away with a crippled crew, perhaps to lose her spars in the next gale, because she had not sufficient men to handle them.

The attack of the "Leopard" on the "Chesapeake," June 22, 1807, intensified the feeling of resentment against the English, though, strictly speaking, it had nothing to do with impressment, but was rather a search for deserters on an American man-of-war. The British government finally made partial reparation, and provided against its repetition by a Royal Proclamation issued Oct. 16, 1807, which directed British officers to restrict them- 
selves to making a demand for deserters, should such a case occur, on the naval officer in command, and, in case of refusal, refer the question to the home government.

The number of cases of impressment was greatest in the early years of the French wars, and diminished after the French fleets were driven from the sea and the pressure on England had lessened.

In 1796, the instructions given by the Secretary of State, Timothy Pickering, to Rufus King called on him to present our side of the question of impressment to the English government, under five heads. He was first to claim that American ships made American seamen, that is, no impressment by the British on the high seas. If this claim was negatived, as it undoubtedly would be, he was to demand that foreign sailors on American vessels should not be impressed, and that certificates of citizenship should not be demanded, since they proved nothing and were frequently lost. He was then to request that the British government 
would agree to relieve from impressment all native-born English sailors who were citizens of the United States, or serving on her vessels at the time of the late peace. Finally, he was to propose two alternative suggestions to the British government: either that they should respect the same rule on an American vessel that they claimed on a British vessel, that three years' service naturalized a man, or that any native-born Englishman who had lived five years in the United States should be free from impressment. These negotiations came to nothing, and the British continued to impress.

The report of David Lenox, who acted as agent for the United States, employed under the "Act for the Protection and Relief of American Seamen," states, that up to Jan. 1, 1799, application had been made to Lords of Admiralty for the release of 651 impressed American seamen. Of these 272 had been discharged, or ordered to be discharged. One hundred and seventy were 
detained, as not being able to prove their citizenship, ninety-three had accepted a bounty and entered the English service, twenty-nine were detained as British subjects, and the balance had died, escaped or could not be found. Of the 170 detained as unable to prove their citizenship, it was allowed that most of them probably were Americans; but with the carelessness of the sailor, they had neglected to carry protection papers, so that out of 651 cases only 29, or one half of one per cent, were found to be English subjects.

A letter from the Secretary of State, of December, 1799, containing abstracts of all the returns made to him by the collectors of the different ports, states that many of the cases of impressment reported at this time were by French privateers. The fate of the men thus taken was doubly hard. They were forced to serve amid a crew alien in race, speech and religion, and as the ultimate fate of most of the French privateers was to be captured by the English, 
they were when thus captured promptly impressed into the British service.

In an ordinary case of impressment by an English man-of-war the name of the vessel so impressing was brought back to the United States, and thus the relatives or friends of the impressed man had some clue to his fate; but in the case above described the man's fate was a hopeless one. He had been robbed by the French of his papers, and was powerless to prove his citizenship. If he accepted the bounty and signed papers on the English vessel, he cut himself off from all hope of returning to his native land. If he pleaded his nationality and refused to work, he was flogged at the triangle. If he worked but refused to sign, he probably got no pay; and after three years' service on an English man-of-war, he became by law an English subject, and liable, should he escape, to all the penalties of a deserter.

The number of impressments into the British service between May, 1803, and 
March 5, 1806, is said to have been $2273,{ }^{1}$ and "By official returns lodged in the Department of State we know of 6257 impressed American seamen." 2

The number given in "Niles Register," 6257 , given by other authorities as 6057 , there is reason to believe was grossly exaggerated.

On Feb. 6, 1813, the Massachusetts House of Representatives passed the following order:-

"Whereas the President in his message has made known to the people of the United States that the British Orders in Council have been repealed, except the claim of the right to take British subjects from the merchant ships of the United States - and, whereas all the European powers as well as the United States recognize the principle that their subjects have no right to expatriate themselves, and that

${ }^{1}$ Mahan, Influence of Sea Power on the War of 1812, vol. i, p. 128.

${ }^{2}$ Niles Register. 
the nation has a right to the service of all its citizens in time of war, - ordered that Mr. Pickering of Salem, Mr. Tillinghast of Taunton, and Mr. Watson of Belfast be a committee to consider and report what measures are proper to be taken to ascertain the number of seamen of this commonwealth impressed by any foreign nation."

The committee thus appointed reported in substance that while the official reports of Mr. Madison and Mr. Monroe showed 6057 cases of impressed American seamen, there were in the report so many cases of duplication, such an absence of particulars of birth and residence, as to make the reports unreliable and valueless. That in pursuance of the order of the Massachusetts House of Representatives they had summoned before them merchants and shipmasters from Boston, Portland, Salem, Marblehead and other seaports, men of all shades of political belief, and questioned them as to their knowledge of cases of impressed American seamen. 
The witnesses who appeared before this committee were of the highest character, typical representatives of our New England merchants. They included such names as Joseph Peabody and William Orne of Salem, Israel Thorndike of Beverly, William Gray, Theodore Lyman and Eben Parsons of Boston and Mr. Story of Marblehead. These men stated in substance that they had employed on the average, for the previous twelve or fifteen years, 1560 seamen annually. This would give an aggregate of 21,840 employed by them since 1799. Of this number, to the best of their knowledge and remembrance, thirty-five men had been impressed. Of the thirty-five, twelve were Americans and twenty-three foreigners. Of the twelve Americans nine were discharged, one escaped and two had not returned. Of the twenty-three foreigners, six were discharged.

The whole number of cases reported by all witnesses, including cases they had heard of on good authority, amounted to 
157. Of these 145 were impressed by the English, eleven by the French and one by the Portuguese. Of the 155 impressed seamen, 107 were Americans, and of these 51 were discharged on application, nine had escaped, four entered the British service, three died, twenty-eight were supposed to be detained, and twelve were not accounted for.

From April 1, 1809, to Sept. 30, 1810, Mr. Lyman, the American consul at Liverpool, made application to the British Admiralty on behalf of 1558 persons. ${ }^{1}$ Of these forty-seven were claimed to have been taken from American vessels, some of them going back to 1803 . The cases actually occurring from April 1, 1809, to Sept. 30, 1810 , were only nine. This latter statement, if authentic, proves what we have already said, that Great Britain was exercising the right of impressment with less vigor than in the early years of the war.

1 Right and Practice of Impressment, Anonymous Pamphlet, London. 
The number of cases of impressed seamen as given by Madison and Monroe seems very formidable; but even without allowing for duplication and mistakes we must remember that this included all men who claimed to be Americans impressed from British and foreign ships, all professed Americans seized by press gangs in English ports, and all foreigners serving on American ships, as well as native-born Americans.

The report of the Secretary of State of April 29, 1816, gives a list of 1420 impressed American seamen confined in Dartmoor prison. Many of these were Americans, who were in the British service prior to the War of 1812, and refused to serve against their own country.

The injuries inflicted on our commerce by the British orders in council far outweighed in national importance the impressment of American seamen; but there is a vivid reality in personal suffering and disgrace, which appeals more closely to the 
human heart than mere loss of property, and the scarred backs of American seamen, and their tales of humiliation and servitude, did more to fire the American heart and kindle bitter resentment against England than all her restraints on trade.

And so we drifted into war, a needless war, a hopeless war, and yet a war justified by a hundred aggressions. In 1807 many had recognized its proximity, some had actually advised it, but all had seen that we were ill prepared. Five years had passed since the embargo, - time enough to double or treble our navy, to put our army on a respectable footing and assume a position commensurate with our commercial importance and wealth. And what preparation had been made for a contest with the first power in Europe? Absolutely none.

The little navy of 1807 had been increased by one small vessel. ${ }^{1}$ The regular

1 The navy of the United States in 1807 consisted of three heavy frigates, the "Constitution," "President" and "United States"; three 38-gun frigates, the "Con- 
army was hardly large enough to police the frontier against the Indians. ${ }^{1}$ The militia was undisciplined, unorganized and poorly armed. The revenue of the country was insufficient to meet its ordinary expenses, and worst of all, a large section of the country was bitterly opposed to the war.

The spirit with which New England went into the contest may be inferred from an article in the "Boston Gazette," referring to the loan for $\$ 11,000,000^{2}$ called for by Mr. Gallatin to provide funds for the war. "They [the Federalists] will loan them money to retrace their steps, but not to per-

stellation," "Chesapeake" and "Congress"; the 32-gun frigate "Essex" and the "Adams," 28, and seven smaller vessels. - McMaster, History of the American People.

1 "One week after declaring war the actual regular force under arms did not exceed ten thousand men, of whom four thousand were new recruits." - Adams, $H$ istory of the United States, p. 295.

2 "The loan for eleven million dollars was opened to popular subscription, but only six million was subscribed. The whole Southern country from the Potomac to Charleston subscribed $\$ 700,000 . "-$ AdaMs, History of the United States, p. 207. 
severe. Let every highwayman find his own pistols." 1

${ }^{1}$ Gouverneur Morris in his Diary states, "A firm union of the Northern States is the only means, under God, to preserve American freedom." He then goes on to 'specify the states that will form the new union, and expresses fear lest Pennsylvania may go with the South. "A Federalist," he continues, "whose vote should in any way support the war, would be guilty of treason." - Diary and Letters of Gouverneur Morris, p. 545. 


\section{CHAPTER III}

\section{AMERICAN TONNAGE AND AMERICAN SEAMEN}

T THE tonnage of United States vessels in 11800 was comprised under three heads: registered, enrolled and licensed. A registered vessel must have been built in the United States and be owned by a United States citizen, and the registry, which entitled the vessel to engage in foreign trade, was given by the collector of the district to which the vessel belonged. All coasting and fishing vessels under twenty tons were licensed and those of twenty and over enrolled by the collector of the district, and such vessels were exempt from clearing and entering at the custom house every time they left or entered port. Those vessels which from any cause could not be registered, but belonged to a citizen of the 
United States, received letters equivalent to a register and were called sea letter vessels. The growth of American tonnage was very rapid from 1800 to 1808 , when the embargo for a time checked its increase, and just before the War of 1812 it reached its highest figure. The amount of registered tonnage for the year 1800 was in round numbers 670,000 tons, and the licensed and enrolled 245,000 tons. In 1807 the registered amounted to 848,000 tons and the licensed and enrolled to 318,000 tons, and in 1811 the registered is given as $\mathbf{7 6 8 , 0 0 0}$ tons and the enrolled and licensed as 386,000 tons. $^{1}$

1 These statistics are taken from Pitkin's American Commerce.

TABLE I

TONNAGE OF UNITED STATES PORTS

\begin{tabular}{l|r|r|r}
\hline & \multicolumn{1}{c|}{1800} & 1807 & \multicolumn{1}{c}{1811} \\
\cline { 2 - 2 } New York & 146,441 & 219,381 & 247,893 \\
Philadelphia & 103,363 & 105,333 & 95,507 \\
Boston & 96,311 & 119,510 & 119,301 \\
\hline
\end{tabular}


The statistical tables given in this chapter are compiled from the returns of the United States Registrar, given in the fourteenth volume of American State Papers.

TABLE I (continued)

\begin{tabular}{l|r|r|r}
\hline Baltimore & 86,892 & 91,832 & 82,988 \\
Charleston & 48,854 & 53,011 & 28,615 \\
Norfolk & 37,929 & & 33,076 \\
Portland & 26,379 & 41,241 & 37,363 \\
Salem & 25,821 & 41,083 & 32,269 \\
Newburyport & 20,615 & 34,640 & 24,021 \\
Portsmouth & 16,854 & 26,840 & 30,005 \\
Marblehead & 19,964 & 21,608 & 16,340 \\
New Bedford & 16,335 & 25,221 & 24,363 \\
Savannah & 9,128 & 14,972 & 2,812 \\
\hline
\end{tabular}

TABLE II

EXPORTS OF SIX REPRESENTATIVE STATES FOR 1810

\begin{tabular}{l|r|r|r}
\hline & Domestic & \multicolumn{1}{|c}{ Foreign } & \multicolumn{1}{c}{ Total } \\
\cline { 2 - 2 } Massachusetts & $\$ 6,042,645$ & $\$ 5,192,820$ & $\$ 11,235,465$ \\
New York & $8,747,700$ & $3,518,315$ & $12,266,218$ \\
Pennsylvania & $5,694,447$ & $3,865,670$ & $9,560,117$ \\
Maryland & $4,553,582$ & $2,280,405$ & $6,883,987$ \\
Virginia & $4,798,612$ & 23,695 & $4,882,307$ \\
South Carolina & $4,650,984$ & 210,295 & $4,861,279$ \\
\hline
\end{tabular}


Table I gives the tonnage of the principal ports of the United States for the years 1800,1807 , and 1811. It will be noticed that then, as always afterwards, New York

TABLE III

TONNAGE OWNED BY NEW ENGLAND PORTS

Boston

Portland

Salem

Portsmouth

Newburyport

New Bedford

Marblehead

Plymouth

Barnstable

Bath

Newport

Wiscasset

New London

Penobscot

Nantucket

New Haven

Providence

Biddeford

Gloucester

\begin{tabular}{|r|r|r}
\multicolumn{1}{c|}{1800} & 1807 & \multicolumn{1}{c|}{1811} \\
\hline 96,311 & 119,510 & 119,301 \\
26,379 & 41,241 & 37,363 \\
25,811 & 41,083 & 32,269 \\
16,854 & 26,840 & 30,005 \\
20,615 & 34,630 & 24,021 \\
16,355 & 25,221 & 24,363 \\
19,964 & 21,068 & 16,540 \\
10,707 & 20,761 & 17,850 \\
13,767 & 18,453 & 16,477 \\
8,563 & 21,758 & 23,303 \\
15,598 & 13,935 & 15,756 \\
11,033 & 16,349 & 16,983 \\
12,673 & 15,330 & 11,737 \\
8,029 & 18,268 & 15,670 \\
11,759 & 17,539 & 16,705 \\
11,611 & 17,027 & 10,229 \\
9,788 & 15,461 & 14,590 \\
9,320 & 8,296 & \\
9,739 & 13,051 & \\
\hline
\end{tabular}


stood first with Boston and Philadelphia competing for second place. Baltimore was a good fourth and these ports were a class by themselves. The paucity of Southern commerce is shown by the fact that

TABLE IV

REGISTERED TONNAGE EMPLOYED IN FOREIGN TRADE

\begin{tabular}{l|r|r|r}
\hline & \multicolumn{1}{|c|}{1800} & \multicolumn{1}{c|}{1807} & \multicolumn{1}{c}{1810} \\
\cline { 2 - 3 } Massachusetts & 213,197 & 310,319 & 352,806 \\
New York & 97,791 & 149,061 & 188,556 \\
Pennsylvania & 95,631 & 93,993 & 109,628 \\
Maryland & 81,508 & 79,782 & 90,045 \\
Virginia & 41,838 & 33,503 & 45,339 \\
South Carolina & 43,731 & 45,222 & 43,350 \\
\hline
\end{tabular}

TABLE V

TONNAGE EMPLOYED IN COASTING TRADE

\begin{tabular}{l|r|r|r}
\hline & \multicolumn{1}{|c|}{1800} & \multicolumn{1}{c|}{1807} & \multicolumn{1}{c}{1810} \\
\cline { 2 - 3 } Massachusetts & 75,080 & 89,982 & 107,260 \\
New York & 51,553 & 75,567 & 83,536 \\
Pennsylvania & 7,380 & 10,353 & 14,255 \\
Maryland & 30,973 & 40,400 & 46,247 \\
Virginia & 26,224 & 27,510 & 31,284 \\
South Carolina & 7,114 & 7,773 & 9,449 \\
\hline
\end{tabular}


south of Baltimore there were but two ports of importance, Norfolk and Charleston. The tonnage owned by a port, however, does not always show the business done, and the exports from some of the other Southern ports were quite large.

North of Baltimore the principal exports were whale oil, fish, live stock, lumber, pot and pearl ashes, rum, furs, beef, pork and mixed agricultural products, together with reëxports of East and West India goods. Baltimore, Alexandria and Norfolk were the great exporters of tobacco, grain, flour, beef, pork, and all sorts of agricultural products. While from Charleston, Savannah and the extreme Southern ports went cotton, rice, indigo, cypress wood, deer skins, hides, pork, hams, turpentine and naval stores.

Table II shows the exports of six representative states for the year 1810. Massachusetts leads easily in foreign exports, and south of Baltimore exports were almost entirely domestic. 
Table III gives the tonnage owned in New England ports for the years 1800, 1807 and 1811. Omitting Boston, Portland retains the lead for the three years, but pushed closely by Salem and Portsmouth. Boston, Portland, Portsmouth and Bath show the greatest gain for the period, and Salem, New Bedford, Plymouth, Wiscasset, Nantucket and Providence show a good increase. Marblehead and Gloucester, the typical fishing towns of New England, reflect the condition of that industry at this period, while New Bedford's large increase was due to accessions to her whaling fleet.

Table IV gives the registered tonnage of six representative states for the years 1800 , 1807 and 1810. Massachusetts heads the list with more than double the tonnage of her nearest competitor, New York. Pennsylvania and Maryland run very close, while Virginia and South Carolina have about the same registered tonnage.

Table $\mathbf{V}$ gives the coasting trade of the same states for the same years. Massachu- 
setts leads New York, but not to such an extent as in registered tonnage. Pennsylvania has surprisingly little coasting trade, perhaps as much as Portland, Me. Virginia and Maryland have less than half the coasting trade of Massachusetts, and South Carolina about one quarter the coasting tonnage of Maryland.

Although the Southern States supplied a considerable portion of our domestic exports, the tonnage owned south of the Potomac was comparatively small and even this tonnage was largely manned by English and other foreigners. ${ }^{1}$ The rich and influential planters of the South had no love for a maritime life, nor perhaps did they care to encourage a business where slaves could not be utilized and which would withdraw a large number of white men from a country which continually oscillated between desire for more agricultural laborers

1 Three quarters of the seamen on southern owned vessels were Englishmen. - Mr. Madison's War, Pamphlet. 
and fear of an insurrection. ${ }^{1}$ The North was the commercial portion of the country, and built, owned and manned the vessels of the young nation.

There were built in the United States in 1800, exclusive of ships sold abroad, fifty thousand tons of shipping. In 1806 the tonnage built rose to 126,393 tons, falling to 99,783 in 1808 , the year of the embargo, and rising again in 1811 to 146,691 tons. The entire tonnage built in all parts of the British Empire during any year for the same period was not over 135,394 tons. ${ }^{2}$

1 The terrible scenes in Hayti beginning in 1791 occasioned the liveliest apprehension in the Southern States. In 1784, twelve ships, one bark and two brigs arrived in Charleston, bringing three thousand slaves. By 1798 the slave trade was prohibited by every state in the Union except New York. That this sudden change in the laws of South Carolina was due to fear lest the negro insurrection in Hayti might lead to negro revolt in our Southern States is shown by the fact that in 1803 South Carolina again legalized the slave trade. - History of Charleston, p. 102.

${ }^{2}$ Pitkin's Statistics. 
From 1800 to 1812 was a period of great commercial activity in the United States, and even where every effort was made to comply with the French decrees and British orders in council, trade with the belligerents and the countries under their control was dangerous. As a matter of fact, however, American merchants made little attempt to respect decrees and orders in council, but ran blockades, bought and forged licenses and trusted to high freights to compensate for the occasional loss of a vessel. The number of American vessels seized, prior and subsequent to the decrees and orders in council, amounted, according to Mr. Monroe, to $1475 .^{1}$ Not all these were condemned, to be sure, but enough vessels were lost to the American marine to keep many shipyards busy. So long as American merchants were willing to risk their cargoes, American ship-builders were willing to build them ships. These vessels were built to order for cash, or were paid

${ }^{1}$ Niles Register, vol. 3, p. 67. 
for partly in cash and partly in objects of barter. ${ }^{1}$

Ship-building was essentially a Northern, it might almost be said a New England, industry and of the New England states Massachusetts stood easily first. In 1811 twelve thousand tons, nearly one twelfth of the entire new tonnage of the United States, was built on the Merrimac River in Massachusetts. ${ }^{2}$

From 1800 to 1812 ship-building was active all along the Maine and New Hampshire coast. In Massachusetts James and

1 The "Archelaus," 500 tons, was built at Exeter, N. H., by Col. Ladd about 1800 . She was three years in process of construction and was largely paid for in merchandise of different kinds. Among other things her builder received a cord of buttons, which were hard to dispose of, until the War of 1812 opened up a lucrative market and he sold them for the soldiers' coats. - BREWSTER, History of Portsmouth, p. 229.

"Many of the vessels built in Boston are loaded with tobacco for Scotch parties who send them to Scotland and pay for ship and cargo in Scotch goods." - Mass. Hist. Coll., vol. 111, p. 287.

${ }^{2}$ Smith, History of Newburyport, p. 262. 
Retire Becket were building at Salem at the yard where for one hundred and fortyfive years the family had followed their profession. ${ }^{1}$ Enos Briggs, one of the most noted ship-builders in New England, was also located in Salem at the yard near the site now occupied by the Naumkeag Cotton Mills, where, up to the time of his death, he had built fifty-one vessels of 11,500 tons burden. ${ }^{2}$ Ebenezer Mann and Christopher Turner as well as Magoun and Barker were also well-known master ship-builders of Salem.

Thatcher Magoun was building at Medford, and Josiah Barker at Charlestown, the Hackets at Salisbury, the Crosses and Merrills at Newburyport, the Westons and Halls at Plymouth, Alden and Elisha Briggs and Jonathan Sampson at Pembroke, Samuel Rogers at Scituate and Edward and Henry Rogers in Boston. Boston, which previous to the Revolution-

${ }^{1}$ Hist. Coll. Essex Institute, vol. 6, p. 132.

${ }^{2}$ Hist. Coll. Essex Institute, vol. 6, p. 207. 
ary War is said to have kept twenty shipyards constantly busy and to have had sixty vessels at one time on the stocks, after 1800 built fewer vessels but of a larger tonnage. ${ }^{1}$ Pembroke and the other towns on the North River not only employed four hundred ship carpenters, ${ }^{2}$ but were technical schools whose graduates were eagerly sought whenever ship-building was carried on.

New Haven, Connecticut, in her three shipyards employed one hundred carpenters, ${ }^{3}$ and Derby and New London turned out many fine vessels. New York, prior to the War of 1812, had three large shipyards, all on the East River. Her most noted ship designers were Henry Eckford, who afterwards built the war ships on the lakes, and Christian Burgh, the builder of the frigate "President." " The number of vessels

1 N. E. Gen. and Hist. Register, vol. 24, p. 279.

2 Ship-building on the North River, p. 69.

3 New Haven Hist. Soc. Papers, vol. 3, p. 168.

4 Memorial History of New York, vol. iii, p. 257. 
built at Baltimore up to the time of the embargo must have been comparatively few, since, Jan. 1, 1808, the number of ships reported on the stocks was only eight. ${ }^{1}$ Baltimore, however, just previous to the War of 1812, was making a specialty almost of schooners which, under the name of "Baltimore Clippers," were known all over the world. ${ }^{2}$ The four shipyards in Norfolk and two in Portsmouth, Virginia, report in 1806: "There is no question about price, only how soon can you get our vessels launched." 3

In the revival of ship-building which followed the Revolutionary War, no other city made such remarkable progress as Philadelphia. What Pembroke was to Massachusetts, Philadelphia was to the United States. Although in 1793 Philadelphia built 8145 tons ${ }^{4}$ of shipping, it was

1 Newburyport Herald, Dec. 14, 1807.

${ }^{2}$ Of the 40 privateers that sailed from Salem in the War of 1812, four were built in Baltimore.

${ }^{3}$ Forrest, Historical Sketches of Norfolk, p. 107.

4 Annals of Philadelphia, p. 2336. 
not so much the quantity as the quality ${ }^{1}$ of the work done which gave her a world-wide reputation. Her principal designer, Joshua Humphreys, was not only a thorough master of all the technical details of his profession, but he was also a man of genius and originality. In 1798, when war with France was threatened, Congress authorized the President to accept "not exceeding twelve vessels of war, on the credit of the United States and to cause evidence of the debt to be given therefor, allowing interest not exceeding six per cent."

The credit for the designing of these vessels, as well as of some built before ${ }^{2}$ the passage of the act, belongs to Joshua Humphreys. It was his idea to make our frigates

1 The bark "True Love" built in Philadelphia in 1748 was in service as a whaler 139 years. Broken up in 1887. The ship "Maria" built in Pembroke, Mass., in 1782 was in service ninety years. The average age of a vessel was said to be twenty-six years. - Ship-building on the North River, p. 172. Nautical Mag., 1889, p. 71.

2 Act of 1794. 
larger and stronger and arm them more heavily than British frigates of the same class, and our almost unbroken naval successes of the War of 1812 were largely due to this fact. His ideas and plans were accepted by the United States government and he personally superintended the building of the frigate "United States," receiving a salary of two thousand dollars a year from the naval department for so doing.

Philadelphia not only had the greatest ship designer in the United States, but she had also the best ship carver ${ }^{1}$ in the world,

${ }^{1}$ From 1200 в. c. down to the beginning of the nineteenth century ornamentation of vessels, especially those of war, was profuse, intricate and florid. A description of the carving on the U. S. line-of-battle ship "America," launched in 1782 and presented to France, will give some idea of the extent to which this was carried. The figurehead was a female figure crowned with laurel representing America. The right arm was raised, pointing to heaven. On the left arm was a buckler with a blue ground carrying thirteen silver stars. On the stern of the ship under the cabin windows appeared two large figures in bas-relief representing "Tyranny" and "Oppression," bound and biting the ground. On the back part of the starboard 
William Rush. Mr. Rush received his education in London, and returned in $\mathbf{1 7 8 7}$ to practise his profession in Philadelphia. His first efforts were directed to modelling in clay, but finding little encouragement for a native artist in Philadelphia he applied himself to the carving of ships' figureheads. In this field he was without a rival, and to a wonderful technical skill he added an artistic sense of beauty and genius for composition which, had his work been done in more enduring material, would have stamped him as one of the best as he was the earliest of American sculptors. He was the first carver to give an idea of life and motion to a ship's figurehead. Each of his figureheads was either the lifelike representation of an individual or some symbolic conception expressed in exquisite carving. His most noted productions were "Nature" for the "Constellation," the "Genius of the

quarter a large figure of Mars. On the highest part of the stern appeared "Wisdom" and above her head an owl. - Brewster, History of Portsmouth, p. 36. 
United States" for the frigate of that name and the "River God" for the East India ship "Ganges." These figureheads were nine feet high and could be removed for repair or in action.

Sea-going vessels were also built on the Ohio and Monongahela rivers and sent down the Mississippi for sale at New Orleans. Their frames were made of black walnut and said to be very durable. ${ }^{1}$

The superiority of American vessels in the early part of the nineteenth century was largely due to our master builders. They were of a different class in society and better educated than their English competitors, and this fact was recognized in England. "The present builders in the different dock yards of this country," says an editorial in the English "Navy Chron-

${ }^{1}$ Some twenty vessels were built from 1800 to $\mathbf{1 8 0 7}$ at Marietta and Pittsburg and sold for ocean service. The largest vessel launched was the "Western Trader" of four hundred tons. The business had assumed considerable importance by 1807 , but was ruined by the embargo. - Naval Chronicles, 1806, p. 299. 
icle" for 1807, "have usually risen from being carpenters of ships of war, and before that time been in low employment in the dock yards. They understand the practice of the art, but not the theory." The master builders of the United States studied their profession both practically and theoretically, and in addition many of them came of families to whom skill in ship-building was as much an hereditament as the family farm. ${ }^{1}$

The American builders were progressive, the English conservative. The English were afraid of our lofty spars and light construction, and when in the War of 1812 they captured one of our clippers they usually lessened the height of the masts and strengthened the hull only to find her no

1 The Beckets began to build in 1655, the Barstows in 1740, the Rogers family in 1722. A little later the Cross and Merrill families were building at Newburyport, the Hackets at Salisbury and the Briggs family all over New England. Son succeeded father in the business and he in turn handed it over to his son. The younger sons in many cases went to other towns to start yards of their own. 
longer a clipper. ${ }^{1}$ American vessels carried more sail, were easier handled, sailed faster, ${ }^{2}$ needed less ballast and carried proportionally more cargo than their English competitors.

The shipyard was usually located on some tidal river, the gently sloping banks of which allowed ease of access and facility for launching. The ship carpenters and laborers worked from sunrise to sunset, earning a dollar a day, ${ }^{3}$ with a glass of

${ }^{1}$ Coggeshall, History of American Privateers.

2 The brig "Rapid" of Portland in 1809 made the voyage from London to Boston in fifteen days. - Portland in the Past, p. 412.

The ship "Valiant," built at Wiscasset, sailed from Boston to France in thirteen days. - Hist. Coll. Essex Institute, vol. 1, p. 60.

Mr. Derby's ship “Astrea” made the run from Salem to the Irish coast in eleven days. - Osgoon, History of Salem.

3 One dollar a day was an average, perhaps, but the pay varied according to the time, demand and character of work performed. In 1780 ship carpenters in the United States were paid ninety cents a day. - WRIGHT, Industrial Evolution. 
grog at eleven and four thrown in. Rum was furnished at all the shipyards and the cost entered into the expense account of the vessel. ${ }^{1}$

The number of ship carpenters employed in the yards of the United States in the early part of the nineteenth century, is nowhere given, but it is possible by comparison to make a fair estimate. In 1811 there were built in the United States 146,691 tons of shipping. ${ }^{2}$ The number of ship-wrights employed in Great Britain in 1807 is given as 8928, exclusive of calkers. ${ }^{3}$ The entire tonnage built in Great

The ship carpenters who built the frigate "Essex" received a dollar and fifty cents, and the common laborers a dollar, a day. [N. E. Hist. \& Gen. Register, 1868.]

In 1805 ship carpenters working on English naval vessels received 7s. 3d. a day. [Naval Chronicles, 1805, p. 497.]

1 The "Lady Gallatin," built in 1813, was charged with $\$ 120$, the cost of eighty gallons of rum and gin furnished from March 22 to Aug. 25. - Ship-building on the North River, p. 178.

2 Pitkin, p. 430.

3 Naval Chronicles, 1805, p. 497. 
Britain for the year 1807 did not exceed 135,394 tons. $^{1}$ If we allow that the workmen of the two countries were equally efficient, then the ship-building interest of the United States must have employed at least ten thousand ship carpenters in 1811. If to the number of carpenters we add the blacksmiths, coopers, sail makers, block makers, painters, rope makers, and common laborers, which ship-building necessitated, the importance of the industry may be imagined.

The number of seamen employed in the United States in any one year from 1800 to 1812 is evidently a matter of guess, since estimates vary greatly. Mr. Gray of Salem and Messrs. Loring and Parsons of Boston, in a hearing before a committee of the Massachusetts House of Representatives, ${ }^{2}$ all testified that, taking large and small vessels together, one seaman to every six tons of shipping was a fair average. If this was

${ }^{1}$ Pitkin, p. 430.

${ }^{2}$ Hearing before a committee in 1813. 
true, - and no one can question the veracity or competency of the witnesses, the number of seamen in the United States from 1800 to 1812 was much greater than that given by any authority the writer has seen. The writer infers, though it is not so stated, that this estimate includes not only able seamen but every officer and man needed to man the ship. The smaller the vessel the more hands needed proportionally.

Vessels employed in the cod and whale fisheries carried one man to every six tons, exclusive of officers. Coasting vessels carried fewer hands proportionally than those engaged in registered trade. The writer has collected statistics of forty-four large vessels in registered trade where the tonnage and number of seamen employed were both given. The combined tonnage of the vessels amounted to 14,877 tons, manned by 912 seamen, exclusive of captains. The vessels averaged about three hundred tons each. The number of sea- 
men to each ton is roughly one to sixteen. If we allow that each ship carried a captain and no others except seamen, ${ }^{1}$ the total number of hands needed to man the ship would be about the proportion of one to fifteen. Taking large and small vessels together, the general average would be one man to each ten or eleven tons.

In 1811 the tonnage of the United States, as given by Pitkin, was 1,232,000 tons, which, on the basis of one man to every ten tons, would give $123,000^{2}$ men as needed

1 The ship "Juno," on her voyage to the northwest coast of America, carried a captain, two mates, a clerk, two armorers, a cook, carpenter, tailor and musician, thirty-six men in all. The "Juno" was 250 tons burden and carried one man to every seven tons.-Monroe, History of Bristol, p. 275.

The famous ship "Massachusetts" on her voyage to the East Indies carried a captain, four mates, a purser, surgeon, three midshipmen, three boatswains, a gunner, two stewards, a cooper, four quartermasters, two cooks, one servant and forty-two seamen. - PoтTer, History of Quincy, p. 493.

2 This estimate is probably too large. Seventy-five to one hundred thousand seamen was the estimate given 
to navigate the merchant fleet of the United States for that year. Twenty per cent of the seamen on American vessels, however, were foreigners, ${ }^{1}$ which would leave 100,000 as the number of American officers and men employed in that year in the United States marine.

To show how authorities differ in their estimates of the number of sailors employed in any one year we quote the following. "Niles Register," vol. 1, p. 379, gives the number of seamen in the United States in 1804 as 64,000 , and in 1809 , when the tonnage was much larger, as 55,000 . The same authority gives the shipping of Great Britain, Ireland excepted, in 1810 as $2,549,680$ tons manned by 164,000 seamen, or one man to every fifteen tons. The in the Salem and Boston papers for 1807-8, the year of the embargo. One difficulty is that in most cases it is impossible to tell whether the number quoted means able seamen only, or includes officers, supercargo, cook and cabin boy.

1 Evidence of Mr. William Gray before a committee of the Massachusetts House of Representatives in 1813. 
“'Tradesman's Magazine,” vol. i, p. 21, gives the number of sailors employed in the British West India trade in 1807 as 14,000 , and the tonnage as 180,000 , or one man to thirteen tons. Mr. Nourse, the United States Registrar, in 1800 reports that the proportion of men to tonnage in the codfishing fleet of that year was one to five. Two years later he reports it as one to seven.

As a matter of fact, the American sailor followed the sea, left the sea, or changed his service, according as inclination or necessity might demand, and estimates as to the number of United States sailors employed in any one year are merely rough guesses.

The wages paid American seamen were, as a rule, higher than those paid by any other nation. From 1714 to 1775 an American seaman's pay averaged about £2 10s. per month. ${ }^{1}$ After the Revolutionary War, wages were higher, but varied according to

1 Weeden, vol. ii, p. 517. 
the length and character of the voyage. The American system by which sailors were allowed to carry adventures on their own account, not only increased the efficiency of the crew to a marked degree, but also added to their wages. From cabin boy to master each seaman might carry his own private venture, unlimited as to value, but restricted as to space. ${ }^{1}$ Sometimes a certain weight was allowed, sometimes the sailor was restricted to his own chest; but, whatever the privilege granted, it made the seaman a partner in the voyage and interested in its success.

From 1800 to 1812, while the United States was the neutral carrier for the world, wages of American seamen were very high. In 1806 Admiral Willaumez writes to the French minister at Washington, "I have

${ }^{1}$ On the ship "Franklin," which sailed from Boston to Batavia in 1798, the first and second mates were allowed two and a half tons privilege and the third mate one ton and the sailors what they could carry in their chests. - Hist. Coll. Essex Institute, 1860, p. 207. 
just apprehended four seamen whom I found on an American brig, where they had engaged at seventeen dollars a month." The seamen on the United States frigate "Essex" were paid seventeen dollars a month, besides prize money. ${ }^{1} \mathrm{Mr}$. Lloyd of Massachusetts, in a speech before the Senate, Feb. 28, 1812, gives the pay of American seamen as seventy-five cents a day, or \$22.50 a month.

Fishermen at this period are said to have averaged seventeen dollars a month, ${ }^{2}$ carpenters a dollar a day and common laborers eighty-two cents a day. ${ }^{3}$

The food furnished the sailors on an American ship in 1800 was good, measured by the standard of the times. Beef, pork and fish, salted of course, beans, peas, corn

1 Extract from a letter to Capt. Preble of the "Essex," from the Secretary of the Navy, Nov. 15, 1799: "Able seamen you will allow seventeen dollars, ordinary seamen and boys five to fourteen dollars a month."

2 History of Cohasset, p. 397.

3 Wright, Industrial Evolution of the United States, p. 216. 
meal, molasses and biscuit were supplied in liberal quantities.

The same coöperative principle which worked so well in the case of the sailor applied more strongly to the captain, since on his business management, as well as his ability as a seaman, depended the success of the voyage. The monthly pay might be, and often was, merely nominal, but his primage, ${ }^{1}$ commission on sales and purchases, and adventure, often netted what would be even in these days a handsome sum.

In 1737 some of the captains trading with the West Indies received as pay twenty shillings a month and one third the profits of the voyage. ${ }^{2}$ In 1784 Nathaniel Tracy of Newburyport writes to Captain Tucker, in command of one of his vessels, "I will allow you $£ 36$ s. a month, five per cent on your sales and two and a half per

1 Primage was sum paid to captain in addition to freight for general oversight of the cargo.

${ }^{2}$ Bourne, History of Wells and Kennebunk, p. 567. 
cent on what you purchase." ${ }^{1}$ In 1813 Captain Coggeshall of the schooner "David Porter" received five per cent primage, and a commission of two and a half per cent on sales. ${ }^{2}$ When we consider that a ship of two hundred tons might easily carry a cargo worth sixty to eighty thousand dollars, the value of primage and commissions can be readily appreciated.

Although the pay received by an American captain in the early part of the last century was large, as measured by the cost of living and the remuneration accorded to other professions, yet the time during which he might reasonably expect to receive this pay was short. Cholera in the East and yellow fever in the West Indies, malarial fever on the African coast and typhus fever in the unsanitary ports of Europe, in addition to the ordinary perils of the sea, carried off hundreds of mariners while yet in the prime of life. Out of 634 members who

\footnotetext{
${ }^{1}$ Currier, History of Newburyport, p. 452.

${ }^{2}$ Coggeshall, History of American Privateers.
} 
have been connected with Essex Lodge of Free Masons in Salem, 293 were mariners. Fifty of these were lost at sea and forty-two died in foreign ports at the average age of thirty-eight. ${ }^{1}$ More than one sixth were lost at sea and nearly one third died away from home.

Of the 120,000 seamen who manned the vessels of the United States, probably one twelfth were employed in the codfishing industry. Codfishing was carried on chiefly from New England, and demanded and produced sailors of unusual ability. No one else could sail a fore-and-after like the men of Gloucester and Marblehead, no one could carry sail longer or be more resourceful in danger. It was the sturdy arms of the Marblehead fishermen which

1 Out of 634 members of Essex Lodge of Free Masons, 293 were mariners, 246 master mariners. Fifty of these were lost at sea and forty-two died in foreign ports. Seventy-four other members were of trades intimately connected with the sea, such as ship-builders, sail and cordage makers and block makers. - Hist. Coll. Essex Institute, vol. 4, p. 225. 
forced the boats through the ice when Washington crossed the Delaware and surprised Trenton, ${ }^{1}$ and it was from the rank of the fishermen that most of the privateers in the War of 1812 were manned. When the "Constitution" bore down on the "Guerrière," eighty Marblehead fishermen stood on her decks. The real fisherman rarely cared to ship on the merchant service; he missed the danger and excitement of his favorite pursuit. What were steady wages and a good balance at the end of the season, compared with the chance of being " high line" of the fleet or a race home from the banks with some long-time rival! No wonder the Marblehead fishermen stood bravely to their guns on the deck of the "Constitution." The annual loss of life on the fishing fleet of Gloucester and Marblehead was greater than sufficed to take the three British frigates, "Macedonian," "Java" and "Guerrière." There was little money made in the fishing business. Vast

1 Roads, History of Marblehead, p. 242. 
fortunes were accumulated from whaling and commerce, ${ }^{1}$ but the useful, modest and dangerous pursuit of codfishing brought little more than a competence.

The number of seamen annually employed in the codfishing industry was roughly reckoned at one man for every five or six tons, and as long as the vessels used

1 In the attempt to secure greater profits from codfishing, combinations of this pursuit with whaling and commerce were attempted. In 1802 Dennis, Yarmouth, Harwich and Provincetown each had a few vessels which went to Greenland for whales and on the return trip stopped at the banks and filled up with cod. - Mass. Hist. Coll., vol. viii, p. 141.

In 1807 an experiment was tried in New Haven which at first bid fair to be successful. A company was formed under the name of the "Derby Fish Co." to carry on a combined fishing and trading business. The ressels employed, which were unusually large and fine, took out a fishing license and were also registered so that they could go to the banks, get a fare and then sail directly to Europe or the West Indies, thus saving the return trip and shifting of cargo. The company did a large business and made money, but war came and in 1815 it was obliged to dissolve. - New Haven Hist. Society Papers, vol. 3, p. 175. 
did not exceed fifty tons burden, this was substantially correct. Prior to 1812, the largest tonnage employed in any one year was 75,000 tons in 1807 , which would make the number of fishermen for that year about thirteen thousand.

The seamen employed in the whaling industry of the United States were also men of unusual intelligence. Besides being sailors, they were coopers, carpenters, rope makers and blacksmiths. The long voyages to parts of the world where conveniences for repairs were limited necessitated skilled mechanics.

The whaling fleet of Nantucket in $\mathbf{1 7 7 5}$ is said to have amounted to 150 vessels, of 14,867 tons burden, manned by 2200 seamen. ${ }^{1}$ This estimate allows one sailor to every seven tons. In 1811 Nantucket is said to have employed ten thousand tons of shipping in the whaling industry. ${ }^{2}$ If the proportion between seamen and ton-

1 Report of Commissioners of Fish and Fisheries, p. 22.

2 Macy, History of Nantucket, pp. 167, 229. 
nage in the two years remained the same, Nantucket in 1811 must have employed about fourteen hundred men in her whaling fleet. New Bedford at this time is supposed to have had as large a whale fishing fleet as Nantucket, and Dennis, Yarmouth, Wellfleet, Harwich and Provincetown each sent out a few whalers, while Boston owned quite a number. Norwich, New Haven and New London, Connecticut, did some whaling, and a few vessels from Rhode Island and New York were similarly engaged. If all the vessels built for and usually employed as whalers were in service in 1811, more than three thousand men would have been engaged in this pursuit. According to Tower, however, in his lately published "History of the American Whale Fishery," the whole whaling tonnage of the country in 1811 only amounted to 5299 tons, which on the ratio we have used would indicate some 750 men as the number employed in that industry. The seamen on a whaling vessel were paid by the lay and 
averaged rather better wages than in codfishing or the merchant service. ${ }^{1}$

After 1796 the seal fishery was carried on quite extensively, chiefly from New Haven. It was closely allied to the East India and China trade, and like that was a trade for rich men. It appealed to the young and venturesome, and in many cases young captains, without chart, chronometer or sextant, ${ }^{2}$ sailed to the Falkland Islands,

1 The "lay" varied from $\frac{1}{18}$ for the captain to $\mathrm{T}_{\frac{1}{20}}$ for the boys. In some cases the owner furnished the ship and supplies and took three fifths of the proceeds. The following is the settlement of the "Sea Lion," which arived in port June, 1807, after a two years' cruise. The captain received $\$ 2070$, the first mate $\$ 1381$ and the men averaged four to six hundred dollars each. - Mass. Hist. Coll., vol. 111, series ii, p. 29.

2 The Naval Chronicles for 1810, p. 325, give an interesting account of the condemnation of an American vessel in the Danish courts, at that time under the influence of Napoleon, because, as the judges reasoned, the lack of a chart or sextant aboard showed that the vessel must have come from England and not America. The protest of the American captains then present in port shows that this failure to carry chart or sextant was no unusual thing. The protest was as follows:- 
rounded the "Horn," touched at St. Felix and the Galapagos, and then proceeded to Canton, where they sold their cargoes at great profit.

The sealing fleet consisted of some twenty ships averaging two hundred and fifty tons burden, manned, it is said, by the best young men of New Haven. ${ }^{1}$ These ships carried crews of forty men each besides the captain, mates, supercargo, surgeon, blacksmith, carpenter and cooper. Including vessels owned outside of New Haven, it is probable that the sealing fleet,

"We, the undersigned, masters of American vessels now in the port of Christiansand, having heard with astonishment that one of the principal charges against the American brig 'Hannah,' from Boston bound direct to Riga, and condemned at the prize court of this place, is as follows, That the said court have pronounced it absolutely impossible to cross the Atlantic without a chart or sextant. We therefore feel fully authorized to assert that we have frequently made voyages from America without the above articles, and we are fully persuaded that every seaman with common nautical knowledge can do the same."

${ }^{1}$ New Haven Hist. Society Papers, vol. 4, p. 146. 
at the height of its prosperity, employed five or six hundred ${ }^{1}$ hands.

The character of the seamen employed in the American merchant marine was exceptional. In no other part of the world were they drawn from the same class in society. In the New England coast towns the well-to-do family of that day - and few were poor - strove hard and pinched to send at least one boy to college, another they placed in the counting room of some merchant, and the rest they sent to sea. These boys might be compared to the midshipmen in the English navy, in distinction from the English sailors. They had all the dogged courage, the pride of race and sea instinct of their English progenitors, but they had in addition a quickness of intellect

1 The "Neptune," 350 tons, owned in New Haven, sailed from New York in 1796 to the South Pacific. She killed and took the pelts of 80,000 seals, selling them in Canton for $\$ 280,000$. She brought back a full cargo from Canton, reaching New Haven at the end of three years, having made probably the most profitable cruise to that date. - New Haven Hist. Society Papers, vol. 4, p. 2. 
and an adaptability which the English lacked. They were really in 1800 the picked men of a picked race, and their ranks were continually reinforced by a stream of green awkward youths who poured in from the country, boys too ambitious to endure the dull life of the farm or boys impatient of restraint who had run away from home, in other words, the most active and enterprising of the district.

In what, strictly speaking, constitutes a skilled sailor, in knowledge of the mechanism of a vessel and the ability to get the best results from that knowledge, there was little to choose between the English and American; but the motto of the one was conservatism, of the other progress. Partly from his nature, still more from social barriers, the English sailor was satisfied to remain a sailor or perhaps a petty officer, while the American regarded the forecastle as the mere stepping-stone to the master's berth. ${ }^{1}$ This possibility, almost certainty,

${ }^{1}$ In or about 1800 Captain Lamson sailed in the brig 
of promotion produced that same enthusiasm in the American sailor which had distinguished the French recruits in the early days of the French Revolution.

The influence of the American sailor was profoundly felt in the religious, political and social life of that day, not only in the coast towns, but far back in the country. The narrow and somewhat gloomy religion he had learned from his fathers was broadened and lightened by intercourse with those of different religious belief, and he brought back to his home a greater tolerance and a broader catholicity. ${ }^{1}$ In politics, where party lines were drawn so sharply on questions of trade, its protection or restriction, his opinion could not be without great

"Mars." The crew numbered thirteen. He says in his Diary, "All have risen to be masters and made first-rate captains."

1 The sailor as a rule was religious but not sectarian. It was the custom in Kennebunk in $\mathbf{1 8 0 0}$ for the master and crew to attend church in a body, the Sunday following their return from the West Indies or any long voyage. - Bourne, History of Wells and Kennebunk, p. 580. 
influence on his relatives and friends. He knew, and probably had suffered from, both France and England; but while not loving the latter, he despised the former. He believed that England, on the whole, was really sustaining the cause of constitutional liberty against despotism, and that, being unprepared to fight, our best policy was to temporize. In the reaction in Massachusetts against Jeffersonian democracy, the sailor was an important factor.

Into the home life of that day the sailor brought the breeziness and freshness of the sea. Books were few and newspapers formal, and the advent of the sailor, with his stories of adventure and accounts of strange countries, did much to dispel the monotony of home life.

Massachusetts had reason to be proud of her sailors. With manufacturing still in its infancy and agriculture barely self-supporting, Massachusetts owned almost the whole of the whale fishery, six sevenths of the codfishery and more than one third of the 
whole tonnage of the United States. ${ }^{1}$ Truly our ancestors were right when they claimed the sea as their heritage.

The romance of the sailor's life has passed, never to return. The use of steam as a motive power, the control given by the telegraph and the employment of iron as a building material, while highly utilitarian, have made the sailor part of a mere machine and stripped him of all initiative. That most beautiful product of the architect's skill, a full-rigged ship, has been replaced by the ugly tramp steamer. The many-masted, barge-like coaster has taken the place of the beautifully proportioned schooner, except as it survives in the fishing fleet, and few native-born Americans man our vessels.

But with the decay of our marine has come no loss of material prosperity. Our country stands as of old in the front rank, and though our triumphs have shifted from the sea to the land, the men to whom they

${ }^{1}$ Pitkin. 
136 CAPTAIN ZACHARY G. LAMSON are due, the men whose efforts made Massachusetts possible and New England what she is, were her fishermen and sailors. 


\section{CHAPTER IV}

7 ACHARIAH GAGE LAMSON was 1 born in Beverly, Massachusetts, May 13, 1783, and died in Granada, Central America, Dec. 16, 1846. The first Lamson to land in this country was William Lamson of England, who was one of the early settlers in Ipswich, taking up his residence there in 1637. William Lamson had a son, John Lamson, whose son William Lamson was the father of Jonathan Lamson. Jonathan Lamson lived in Hamilton, formerly a part of Ipswich, and was the father of Nathaniel Lamson. Nathaniel Lamson, who was a merchant in Beverly, married Jean Gage, a daughter of Zachary Gage, a descendant of John Gage who settled in Beverly in 1633. Nathaniel Lamson and Jean Gage Lamson had eleven children, one of whom was Zachariah or Zachary Gage Lamson, the writer of the 
"Diary" we publish. Zachary Lamson married Mary Brown of Hamilton, Oct. 6, 1807 , and had six children, the last of whom died in 1899.

Captain Lamson is described as a handsome portly man with curly hair and laughing blue eyes. He was a thorough sailor, a competent navigator and had the reputation of keeping good order and discipline aboard his vessels. He had the merit, not unusual in those days, of being a good supercargo as well as a good captain. He was never afraid of assuming responsibility, and having once decided carried out his plans with great persistency and skill. He was generous almost to prodigality, and made and lost large sums of money with equal facility. He was cool, prompt and resourceful in danger and of the most undaunted courage. He was of an ambitious, optimistic temperament, a good father and a kind friend. But with all the qualities apparently necessary to secure success, Captain Lamson was followed by the most persistent ill 
fortune. From the testimony of those who knew him and the record in his "Diary," these misfortunes do not seem to have been the result of personal mismanagement or neglect, but rather of what is called bad luck.

Of his boyish life we know nothing beyond the few lines in his "Diary" which tell of his education, but we do know that in his burning love of the sea he was but typical of thousands of other New England boys of that day, and it is not difficult even now to reconstruct the path which led from cabin boy to merchant and to show why, to use his own quaint language, "The seafaring life was their constant wish to follow."

How could it be otherwise? The call of the sea to every New England boy's heart along that rocky coast was at once alluring and imperative. The boy could remember how, when a little child, his mother held the big conch shell from the mantelpiece to his ear that he might hear the roar of the 
ocean. A few years later he was wading on the flats sailing mimic boats, or if the day was stormy, rigging them in the barn. Before he knew the "rule of three" he could tie a reef knot or explain the intricacies of a bowline on a bight. The name of every vessel owned in the town was familiar to him, and which was the fastest sailer. On rainy days or in sickness when other amusements failed his mother would bring down the "treasure chest" from the attic, and there the boy would sit and revel in the spoils his sea-going ancestors had collected; seashells of every shape and color brought from foreign shores, a string of pearls, none perfect, from South America, the carved shell of a cocoanut, a shark's tooth, curiously carved ivory boxes from India and a phial of gold dust from Africa. He had seen them a hundred times before, but they were ever new, and each brought a message from the sea.

As he grew older, winter evenings at the store, he would join the group about the 
fire and listen to stories of the sea, some of them apocryphal no doubt, of sharks, mermaids, storms, wrecks, and, most exciting of all, 'of pirates. One of the narrators, perhaps, had been taken by the Algerines and bore on his feet the scars of the bastinado. Another had been captured by pirates on the Spanish Main, and marooned on some barren key until rescued by a passing vessel. Or better still, for the war was recent, he might listen to the tale of some old sea dog who had helped hoist the rattlesnake ${ }^{1}$ flag on the "Alfred" or crossed pikes with the British over the rail of the "Bon Homme Richard."

The social life of the town too had its influence. The minister was revered, the family physician loved and respected, the lawyer admired for his learning; but the autocrat of the place, the one to whom all

1 This flag was raised by John Paul Jones some time in December of 1775. Beyond the fact that it was a flag of the rattlesnake pattern, its design is not certainly known. - Harrison, Stars and Stripes, p. 144. 
deferred, was the great ship-owner and merchant. He had dared the perils of commerce and won, he was the model on which the young men hoped to shape themselves. As the boy went to school he could see the great square house of the merchant prince, three stories high, painted white, set flush to the street, beautiful in its simplicity, with its formal garden bordered with box and crowded with roses, pinks, peonies and phlox and in some retired corner a little patch of sweet herbs. Back of the house stood the barn and to one side and back of that stood the orchard, and few of the boys of the village but had tasted of its fruit legitimately or otherwise. Once or twice, too, the boy had been in the great house and had wondered at the massive sideboard covered with china and silver, at the great punch bowl on the dresser, the quaint Dutch tiles about the fireplace, at lacquered cabinet and carved chest of drawers. But what pleased him most of all were the exquisitely carved chessmen, too fragile 
for real use, wild Mohammedan troopers riding on ivory horses and stately Hindu rajahs perched on elephants' backs. There was no envy in the boy's heart as he saw these things, but rather the proud consciousness that all this was the fruit of personal endeavor and that he too might some day win a prize as great. To this end he studied at school. He might hate mathematics, but without learning navigation how could he sail his ship? and so he learned his lessons. When fourteen years of age he begged to be allowed to go to sea, when fifteen he argued that he should be allowed to, and when sixteen he was not longer to be restrained, and his parents yielded. And the boy was really older than his years. He had learned that lesson which comes naturally to the brute creation, but late or never to the youth of to-day, self-reliance.

He shipped, not through the cabin windows, but in the forecastle, and though his own brother might be captain he fared no better than the merest stranger. The crew 
were probably all from his own town or its immediate vicinity, men of good Puritan stock and good home training. Some may have been wild and reckless, a few depraved, but the great majority were clean, honest men of intense virility and laudable ambition. Even on his first voyage the boy was allowed to take a venture, it might be a quintal of fish or a bag of potatoes, but however small, it made him a partner in the voyage and taught him to buy and sell. The boy rose by being always competent to take a higher position, and by the time he was twenty-one ${ }^{1}$ he had attained his first ambition and was captain of the vessel. What that meant in those days it is hard for us to understand. He left his home port perhaps with a cargo valued at one hundred thousand dollars, and his instructions from the owner for the voyage might not have

${ }^{1}$ On one of the East India voyages from Salem, the Captain, Nathaniel Silsbee, the first mate, Charles Derby, and the third mate, Richard Cleaveland, were all under twenty years of age. - Osgoon, History of Salem. 
covered half a sheet of note paper. ${ }^{1}$ When the captain had crossed the bar and was on the open sea, he was his own master, and, except that he must try to reach the port he sailed for, free to sail wherever and buy and sell whatever he wished. It was not enough that he could navigate his craft skilfully; he must be a close buyer and a shrewd seller, and that he was both all the world allows. If it seemed best to him he

\section{INSTRUCTIONS}

The Ship Wells under your command being ready for Sea you will embrace the first opportunity and proceed for St Sebastians in Spain upon your arrival apply to Mess B. \& Sons and request them to sell the Cargo now on board the Wells for my act for the most it will fetch and if any merchandise can be obtained there that will answer in this Country then have the proceeds of the present Cargo invested in such Articles which ship in board the Wells for my acct with which proceed directly for this Port in case you cannot find any merchandise at St Sebastians that will answer to bring to the U States then have the Proceeds remitted when you can do it most to my Interest, and proceed to the Cap de Verds for a Cargo of Salt and from thence to this Port, 
might sell both cargo and vessel ${ }^{1}$ and send his crew home by another ship. Yet with all this love for a bargain he was generous in his nature and prodigal in his personal expenditure, and in many a case when hurrying to some port where to arrive first was to take the cream of the profit, he would lay by some stranger in distress and sacrifice personal gain to assist his brother sailor. - That he was personally brave goes without saying, for he had not only to keep his crew

${ }^{1}$ In 1802 the ship “Juno," 250 tons, DeWolfe master, made a voyage to the northwest coast after furs. Soon after her arrival she fell in with a Russian vessel having on board a Russian nobleman who had been appointed Ambassador from that country to Japan. The newly appointed Ambassador expressed his intention to build a vessel on the coast to take him to his destination. Captain DeWolfe promptly offered to sell his ship, and they traded for $\$ 68,000$. Part of the crew were sent on to Canton in a vessel of forty tons which Captain DeWolfe bought from the Russians, and part remained on the coast until other means of returning were found. Captain DeWolfe reached home in two years and six months from the time of sailing, having made $\$ 100,000$ net profit on the voyage. - Monroz, History of Bristol, p. 275. 



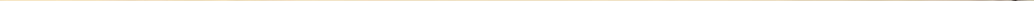




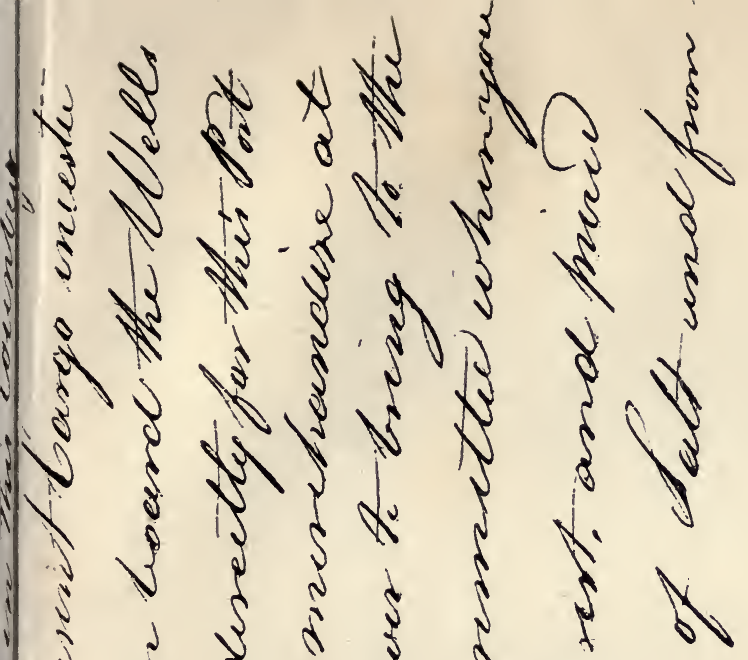

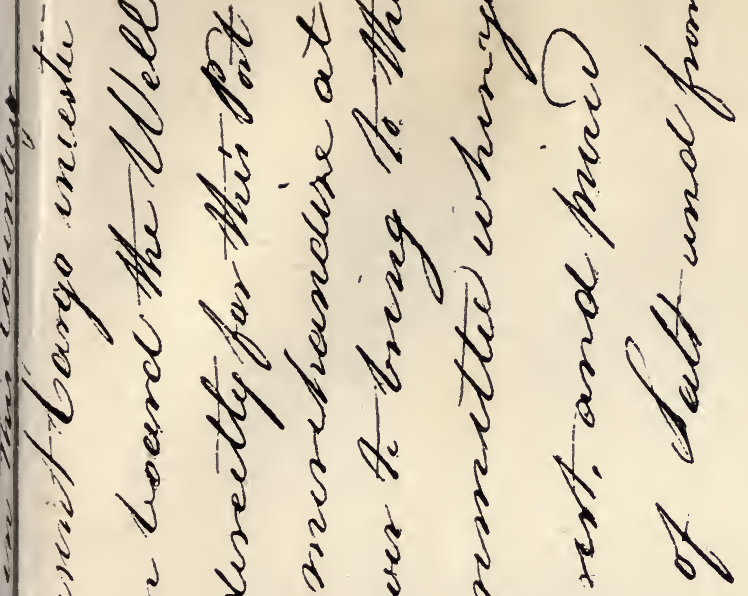

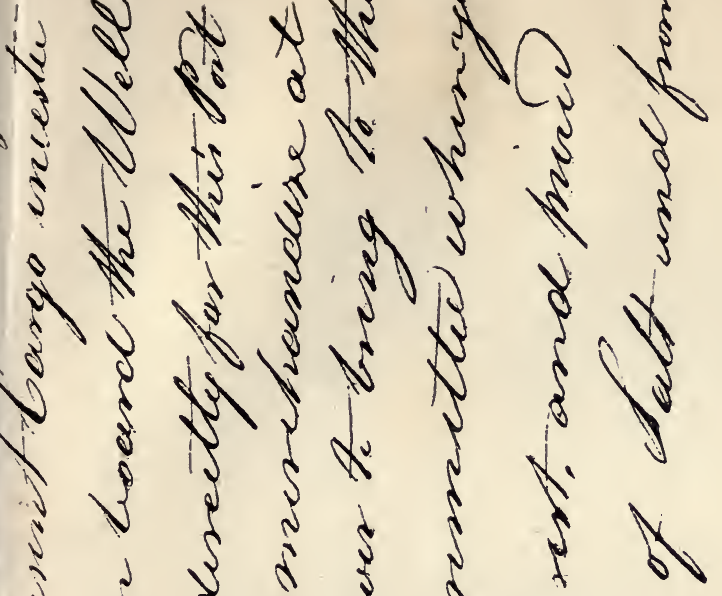

$5: 8 \frac{3}{3} 5$

?

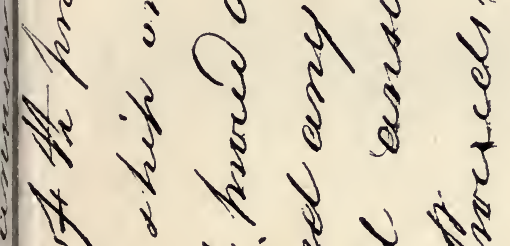

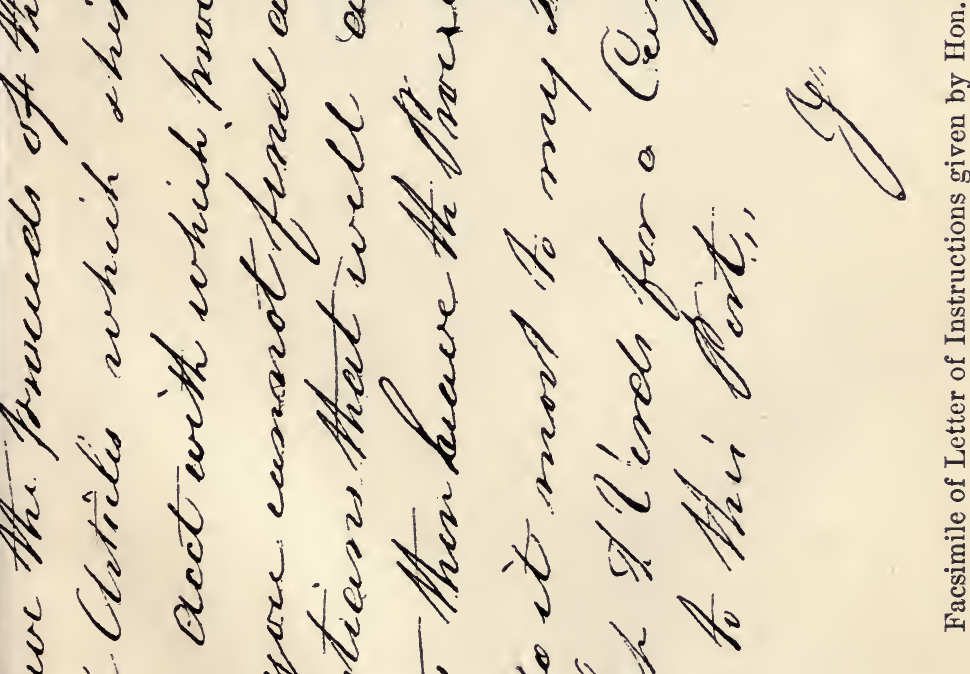

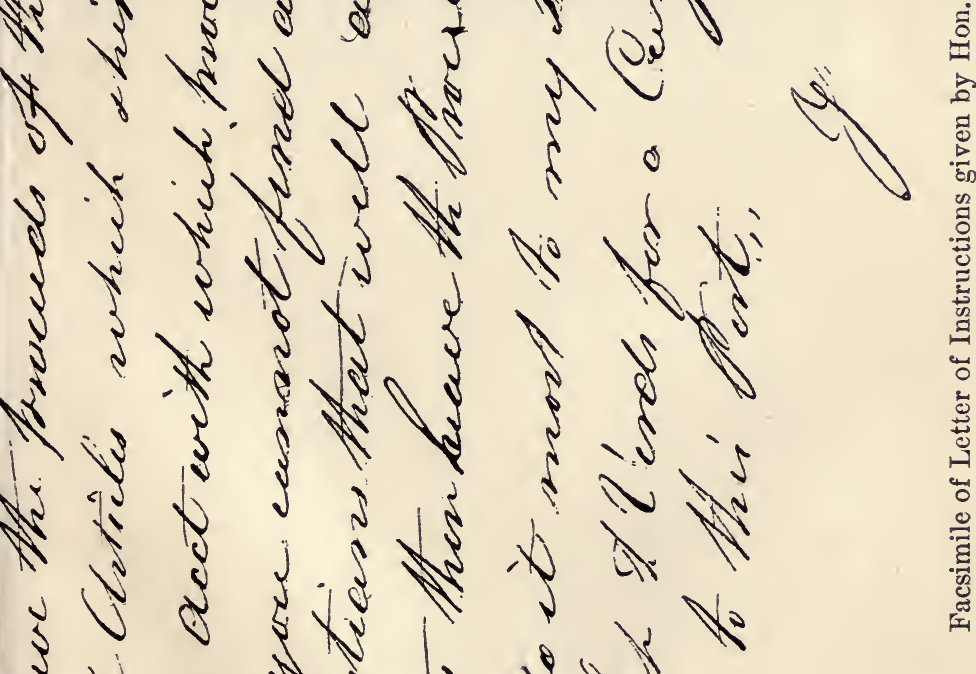<smiles>[AlH2]</smiles>

$\sqrt{2}$

ग)

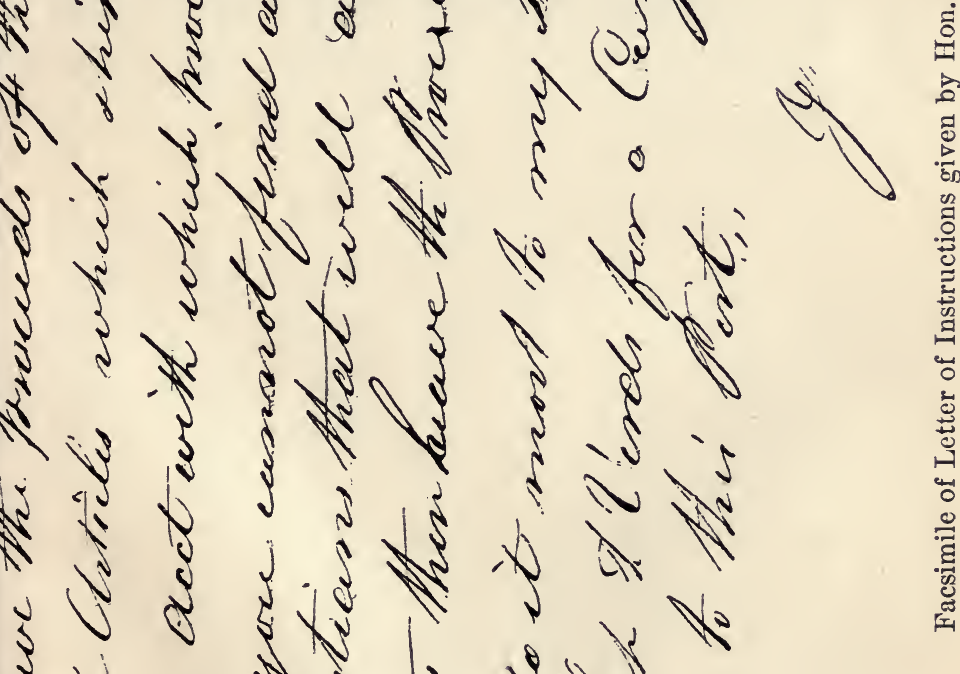

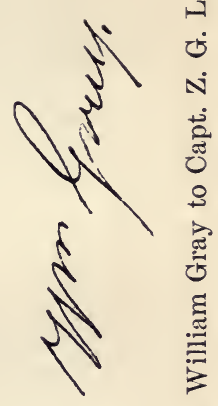

ฮี

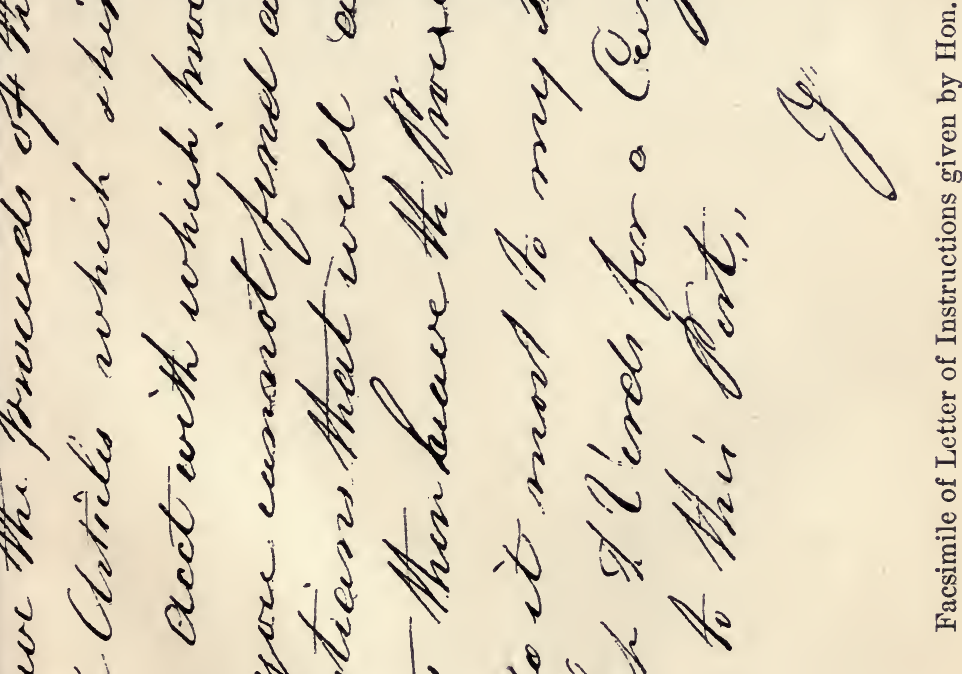

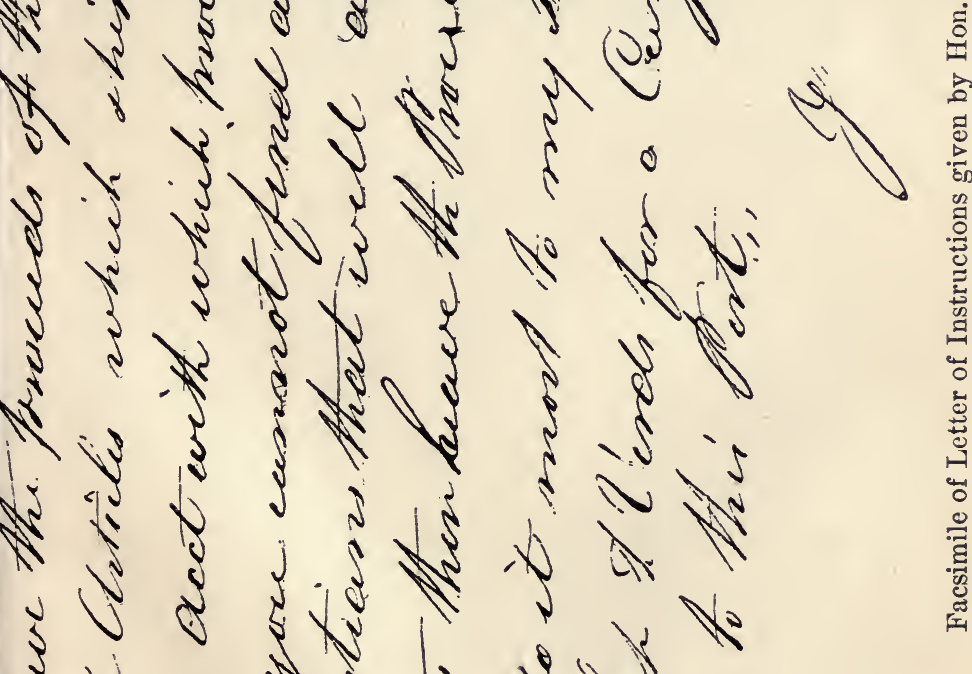

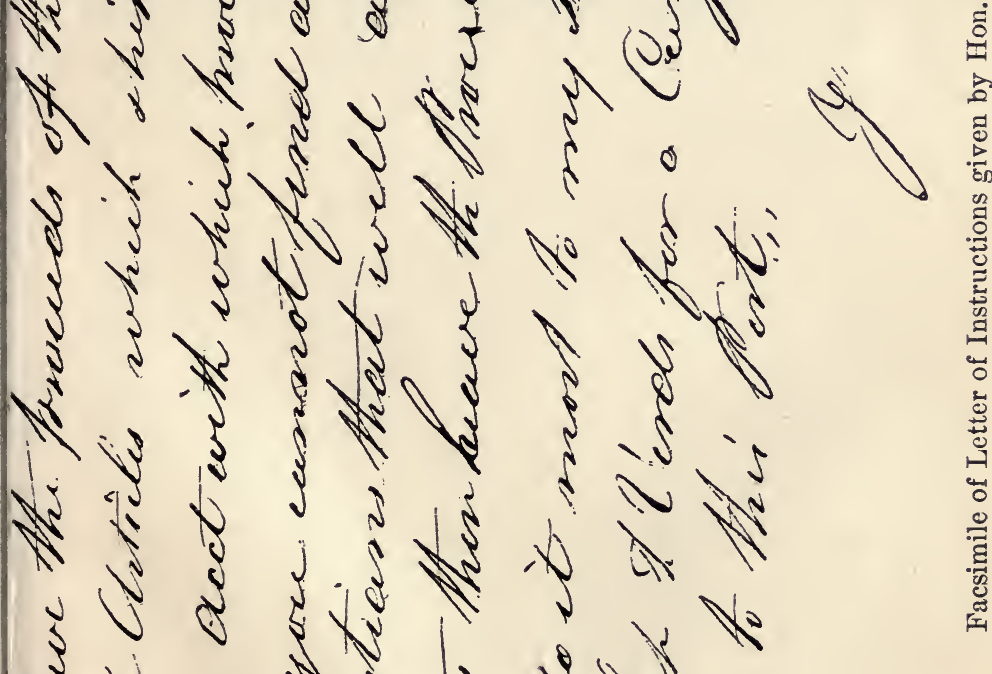

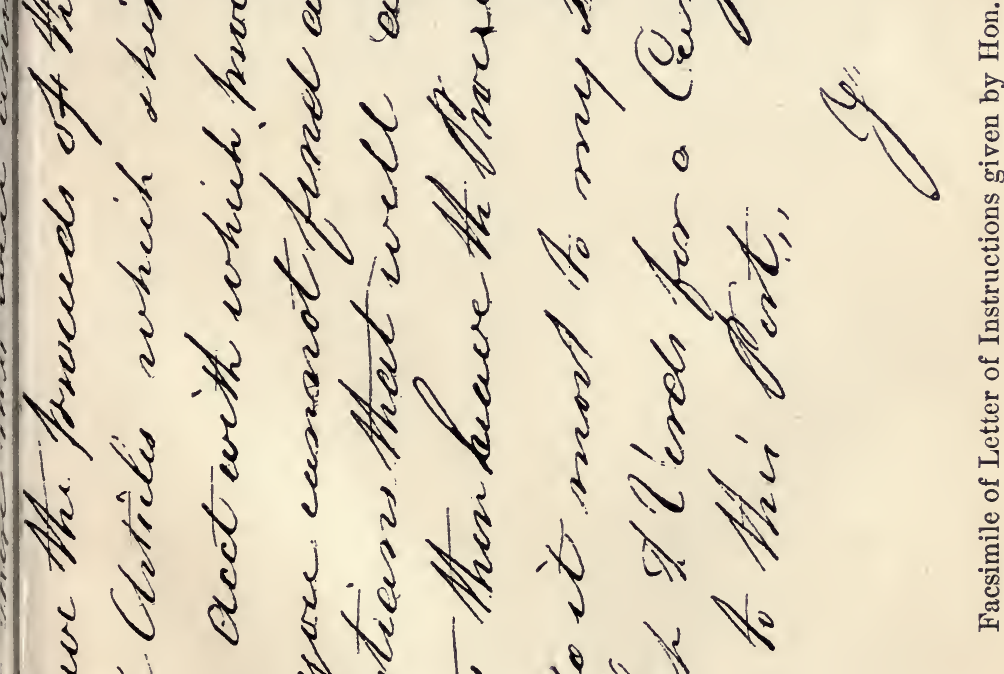

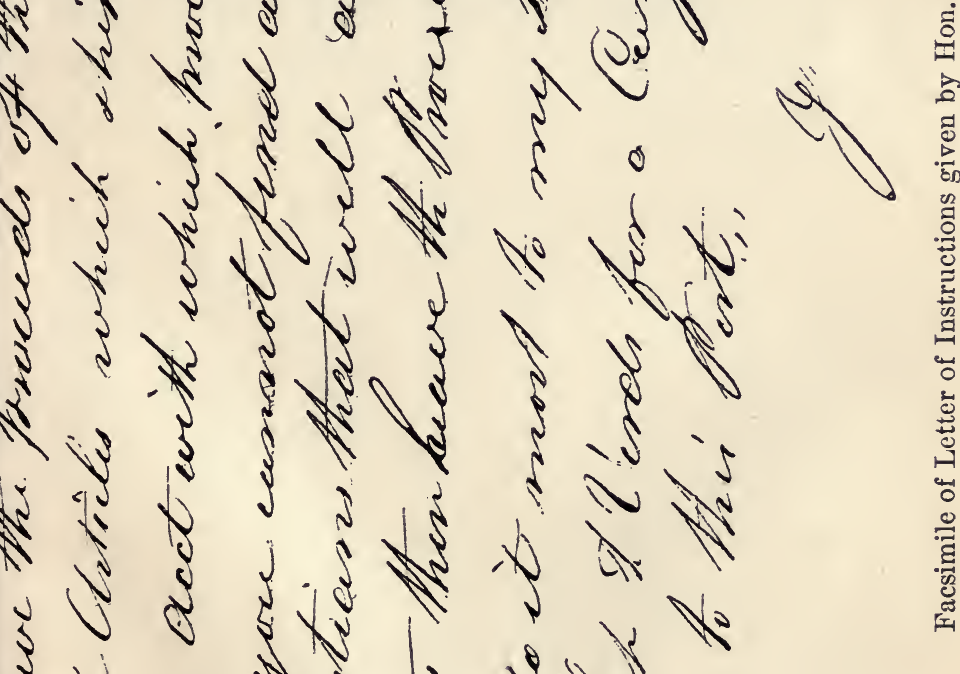

3.

$\sqrt{3}-3-2852 x$

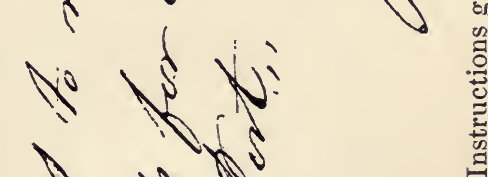



in check and face the ordinary perils of the sea, but from 1800 to 1825 not a vessel left port but ran the danger of piratical attack. Not a vessel sailed the Spanish Main, passed the Straits of Gibraltar or ventured near the Malay Archipelago but must stand ready to fight to save its crew and cargo. The captain of that day was inclined to be boastful and obtrusively patriotic, and his patriotism was too often local and subservient to his business interests. This was true, however, of other professions and in every section of the country. The United States had not at this time been welded into a nation, but was rather a loosely connected league of states and districts with different interests and often antagonistic feelings.

Such a man as I have described the boy had grown to be, and threading his way from port to port, following his market from the Cape of Good Hope to the Orinoco, he gradually acquired wealth and became the owner of a small fleet of vessels. He had now attained his second great 
ambition, and giving up the sea he built for himself a big white house in his native village, much like the one he had admired in his boyhood, and became a ship-owner and merchant. He was now one of the great men of the town, and expected and received a certain deference, for, while democratic in his manners, at heart the merchant was somewhat of an aristocrat. Every morning at precisely half-past eight he might be seen leaving his house for the counting room, his three-cornered hat set upon a head held high, not so much from pride as necessity, for the voluminous stock and extremely high collar of his long-tailed blue coat allowed no other position. His hair neatly plaited in a cue, his nankeen waistcoat embellished with shell buttons and absurdly long, his tight-fitting knee breeches and silk stockings, showing to advantage his shapely limbs, his neatly blacked shoes with bright steel buckles, together with the silver-topped malacca cane which he carried in his hand, all com- 
bined to present a picture of elegant and dignified prosperity. The merchant gave liberally to church and charity, encouraged learning, was a power in politics, entertained royally and was in the best sense of the word a polished gentleman.

But it is not given to all to succeed, and if after a manly fight, the boy now grown old returned to his native village unfortunate and little better off in worldly wealth than when he left it as cabin boy, if he found that the clerk or farm hand whose humdrum life he had despised had passed him in the race, still his life at sea had taught him to accept the mutabilities of fortune; and as memory went back over the kaleidoscopic changes of his career, he could say with some satisfaction at least, I have lived.

It was not given to Captain Lamson to succeed, but he certainly had lived. Wrecked when a mere boy on Cape Cod, wrecked in mature life on the "Blue Caicos," alternately a prisoner on French and 
English war ships, twice captured by pirates and three times beating them off, following his fortune in South America with alternate success and failure, Captain Lamson played the game of commerce for all it was worth; but the cards were staked against him and when he died in Granada, C. A., at the age of sixty-three, he was poor in all but experience.

The fragmentary account of his life which we publish was written at an unknown date and had for its title, "The Diary of Zachary Gage Lamson written by himself." The "Diary," including a slight reference to childhood, covers his life from the time he shipped as cabin boy aboard the bark "Essex" in 1797 to and including part of his voyage in the brig "Isabella" in 1814. Though the "Diary" was written long after most of the events recorded, Captain Lamson was very accurate in his dates, and the files of the Boston and Salem papers confirm his facts. Although his style was at times labored and his sen- 
tences involved, we give the "Diary" exactly as it was written except that a few illegible words have been supplied as the context might indicate. The "Diary" ends abruptly, indicating that a portion has been lost or destroyed. 


\section{CHAPTER V}

H AVING a considerable portion of time 1 while at sea which, for want of employment, I have made use of for the purpose of giving my family the outline of the various incidents relative to my passage so far in the world's voyage.

In my early years, say from five to fourteen, I was pretty generally kept at school in town, where we were provided with excellent masters who taught us the common branches, say arithmetic, writing, reading and spelling. I studied the Latin Grammar and Trigonometry and the Elements of Navigation when fourteen years of age with the Rev. Joseph McKeen, ${ }^{1}$ who was after-

${ }^{1}$ Rev. Joseph McKeen, born in Londonderry, N. H., Oct. 15, 1787. Graduated from Dartmouth College, 1774. Taught school for several years. Ordained over lower parish in Beverly May, 1785. President of Bowdoin College Sept. 2, 1803. Died July 15, 1807. 
wards President of Bowdoin College. I did invariably as well in my studies as boys in general at that age. My father, not having a wish to send me to sea, and hoping I would select some other mode of business on shore, his best efforts were to take me to Boston to Samuel Parkman, then a large importing merchant, where I had the offer of staying with him; but my mind being of the speculative and uneasy make I could not content myself. Accordingly, I advised my father that the seafaring life was my constant wish to follow. He, like a prudent man, would not rashly forbid it, consenting that I should go. Accordingly, November, 1797, I embarked on board the Essex, ${ }^{1}$ Benjamin Henderson, Master, belonging

Many of the coast towns had schools especially devoted to instruction in navigation. One in Manchester, Mass., kept by Stilson Hilton, is said to have numbered forty masters of vessels among its graduates. - LAMson, $\mathrm{His-}$ tory of Manchester, p. 107.

There was also a similar school in Salem, Mass.

${ }^{1}$ Brigantine "Essex," 197 tons, built in 1789, altered to a bark in 1794, William Orne, owner. 
tọ William Orne Esq., bound for the port of Havana in Cuba.

I was in the capacity of cabin boy on board, and it being a very cold day and a high northwest wind on our sailing, and as I was unacquainted with sickness, I suffered much, lying in the middle steerage for nine days. In the meantime my great toe was frozen, so that after my sea sickness subsided, I could only bear silk socks which the mate, Mr. Con, provided for me.

To give an idea, which I believe is prevalent among young beginners on going to sea, while I was sick my constant inquiry was, "Do you think the Captain will put back ?" which if he had, I do think I never should have gone again. I did pray that he might return. However, we continued our voyage and arrived safe in about thirty days. I recollect we sold our cargo very well and a small adventure I had of fish and butter which cost me eighteen dollars. I obtained something like forty dollars of which I expended one-half in fruit while I 
was there. We lay in Havana and took aboard our cargo of molasses and sugar. Just before lading, the Governor of Cuba ordered an embargo on all vessels in port until a fleet of Spanish ships should sail for Mexico, consequently, we lay till the first of May, when we sailed with about one hundred and fifty sails, of American mostly, for our respective ports.

We shaped our course for the Florida channel and on the second night, while we were going at the rate of seven knots an hour, we discovered white water. The captain and officers were uncertain which side of the channel we were on, and in a few minutes the bark struck and continued a little longer when she struck and broke off her rudder, unshipped it and keeled over so that our lee-gunnels were in the water. Our captain was in great distress, as well as the second mate, at the horrid appearance of the night. The wind was strong and the breakers high, and our false keel had come up alongside, our plank to the starboard, on 
our stern, had torn off, our cabin was open to the sea, but a foot or two clear. Finally our captain ordered our long boat out. We had thrown overboard everything from the deck we could conveniently in getting the boat clear. Our chief mate, the only man who kept his presence of mind, observed to the captain, "Sir, are you going to leave the vessel?" The answer was, "Yes." I was ordered below to get bread, brandy, etc., for the boat. The mate, Mr. Con, called on the people saying, "Who will stay by the ship?" Several replied they would. He immediately ordered all sail made while the captain was looking on with anxiety for the result. In about twenty minutes the ship was over the reef, when he cast the anchor from the bow and brought up in three and a half fathoms of water, quite smooth. We lay until daylight, when we hauled our rudder on deck, repaired it and took hides and lined our stern with them as substitute for plank, and at four P. M. we weighed anchor and sailed off 
the bank. I was then quite young. I only recollect we were to the South'd of the bank and our draft of ship was fourteen feet, and on the shoal only ten feet, so that the heavy press of sail was what saved us by cutting the coral and getting over. We were fortunate in weather, as we had only eighteen days after to sail.

As I had now got home and felt the fears subside of seasickness and of that night of disaster, I began to talk large of the seas and its casualties. One thing my father had been informed of in my adventure what it sold for, and finding I had one tierce of molasses only, did not like my frugality. He took me into a room with him and expatiated on prudence and economy and actually made me ashamed of the extravagance I had been to.

Remaining at home about five weeks, I entered on board the schooner John, ${ }^{1}$

1 Schooner " John" of Beverly, seventy tons burden, built in Newbury in 1785, owned by Samuel Ingersoll, John Stephens, Thomas Stevens and Moses Brown. 
Samuel Ingersoll, master, in the capacity of cook, bound to Martinique. We had about thirty days passage, sold our cargo well, got a return cargo and sailed for home where we arrived in September. The only remark of note that voyage bears was the eccentricity of the captain and my awkwardness in cooking. Captain Ingersoll was a very humane man and very moderate. He put me before the mast on my passage home and put a young man, who shipped as a hand, in as cook. I can remark with propriety that my ambition always obtained for me any favors from those sailed with, so that I never felt any diffidence asking them.

On remaining at home about two months, I entered upon the Brig Mars, ${ }^{1}$ Salem, Joseph Orne, master, belonging to William Orne, Esq., in capacity of light hand. We had a large crew, say thirteen in number,

${ }^{1}$ Brigantine "Mars," 152 tons burden, built in 1784, William Orne owner. Wrecked on the coast of Nova Scotia in 1802. 
and five guns with small arms. We sailed for the Mediterranean bound for Barcelona. We passed Giberalter in twenty-five days. Off Cape Gata, we fell in with a Salem ship, the Minerva, ${ }^{1}$ Captain West, which was also armed and bound for Barcelona. We agreed to keep in company, and on the next day at daylight we discovered a large Zebec with the Algerine colors flying. They bore up for us. We took in our light sails and got ready for him. He kept for us. Coming within gun shot he fired two or three guns and we returned our stern chaser, but I presume no damage was done. We arrived safe at Barcelona, sold our cargo and loaded with wine, fruit, etc., we proceeded for Giberalter and had a very tedious passage down, being twenty-six days to the rock, having carried away almost all our spars. We refitted and sailed as soon as we could and had a tedious passage home. We became short of water,

${ }^{1}$ Ship "Minerva," owned by Crowningshield and West. The first Salem vessel to circumnavigate the globe. 
beef and bread, and in consequence of the captain and officers disagreeing, the crew became mutinous and our vessel was a constant scene of debauchery. The captain lost all respect and we were in danger of our lives part of the time. Fighting and quarreling was the word of the day. One thing is very singular as regards the crew, - they were all first rate as seamen and all have risen to be masters, and have made first rate captains in respect to order and discipline on board their ships. When we arrived in Salem the authority of the crew was so great with the captain, he would not see the crew when they were paid off. I was selected by the owner as one to remain by the vessel till the others were clear, and in two or three days after, I was called into the counting room and the clerks were ordered out, when Mr. Orne and son requested me to give a correct statement of the proceedings of the voyage, as regarded the conduct of the crew and of the captain. My situation was delicate, consequently, I 
refused making any observation against either. They then said they wished me to go in the Brig again. I replied that I should stop at home awhile. Then they tried to obtain my reason for not going, but I evaded the principal reason. However, in justice to the captain as related to his treatment of me, I must say that he never abused me in that manner that I noted. An unfortunate habit of swearing was what he suffered mostly by. His passions were too powerful for his reason and patience. I perfectly recollect one day, after he had called me all the most profane expressions he could make use of, in less than two hours he came down and commenced a very lively conversation; and, in the midst of it, he observed to me that if he cursed me to take no notice of it, so that with all the uneasiness on board I never felt the least animosity to the man, and my objection to going again was that it was impossible for him to have a great ship, and it was quite uncertain to find so good an officer as Jonathan 
Cook was, who likewise left him. A few days after I left the Brig, Captain Orne called on me to go with him again, promising to put me forward if I would go. I certainly wanted a friend, but my father, to whom I related the transactions of the voyage, set his face against it and I declined.

After a while I embarked on board the Schooner Rachel ${ }^{1}$ of Beverly, Thomas Woodbury master, as ordinary seaman and bound for the Island of Tobago. We sailed from Beverly about September and had a deck load of sheep on board, say about seventy. Off Cape Cod we had a hard gale. The second night out, we drowned about fifty of the sheep. ${ }^{2}$ A more dismal night I had never seen than that, as the sheep in the

1 Schooner "Rachel," 71 tons, built in 1789.

${ }^{2}$ Horses, mules, horned cattle and sheep were exported in large numbers to the West Indies, usually as a deck cargo. In 1785 New London sent over eight thousand horses to the West Indies and Norwich, on her "horse Jockeys," as they were called, in 1789 exported 1800 head of live stock. - CaULKINS, History of Norwich, p. 478. 
height of the gale were continually crying, and our expectation was the shore. Fortunately at eight A. M. the wind wore suddenly off to the west and we saw Cape Cod about five miles from us.

I continued with Captain Woodbury, making four voyages with him, two to Tobago, two to Cape Lucia, and had then seaman's full wages ${ }^{1}$ and being about seventeen years old. I remained a little time at home, and then entered with Captain Zebulon Ober on board the Victor and made a short trip of six weeks to Newburn, N. C. Our crew was John Tittle, Simeon Bickford, ${ }^{2}$ and myself, and as we were all young and healthy looking, and kept ourselves well dressed, in Newburn we became noticed by all the inhabitants, who did not hesitate to invite us to their houses, and when we could contrast the difference in the

1 At this time about fifteen dollars a month.

${ }^{2}$ Simeon Bickford, according to Salem custom house records, was about the same age as Captain Lamson, and went to sea the same year, 1797. 
appearance of the young men in Newburn with our own companions, we ceased to wonder that we were noticed as we were.

On our return from Carolina I embarked with Captain Gideon Rea ${ }^{1}$ in a schooner belonging to Messrs. Stephens of Beverly and E. Francis of Boston for Jacmel and Aux Cayes. We arrived out safe after a passage of twenty-eight days and vessel leaking badly. We sold part at Jacmel and proceeded for Aux Cayes, where we sold the remainder and found it very sickly, the fever raging badly. ${ }^{2}$ We had finished load-

${ }^{1}$ Gideon Ray was the son of Joseph Ray of North Beverly. Joseph Ray was captain of a company, raised in Beverly and Lynn, which fought with Washington in New Jersey.

2 The mortality among the crews of vessels trading with the West Indies was very great. Vessels would leave the West India ports with a full crew and later be found drifting helpless with only a man or two aboard. The Boston Chronicle of June 12, 1802, reports that the schooner "Hope," from Jamaica to Boston, was spoken May 10, "all the crew dead with yellow fever, except the captain and boy." The ship "Lucia" arrived from Havana, July 16, 1769, having lost eleven of her crew from yellow fever. 
ing our cargo and had got clear for sea, when the captain came on board and told me that the vessel must be got underway, and that he felt quite unwell, and the mate Mr. John Stone was taken unwell the same morning; they both had a high fever. I proceeded to sea as ordered, Captain Rea frequently on deck, till I doubled Cape Tiberon on the next day. The third day out, Captain Rea was struck with death at the table eating his dinner. He was put in his bed and died in about an hour in a violent delirium. We were but five of us, myself one of the youngest, and part of us not in good spirits. Our situation was rather distressing. At five P. M. we had the corpse prepared for interment. Mr. Stone, the mate, who I had endeavored to reconcile, and who was very weak, then consented to attend the burial, while I read several chapters appropriate to the interment of a person, in the absence of a church book. We had no sooner committed the poor captain to the deep, than Mr. Stone fell away in a 
swoon and was near gone; however, he lived three days afterwards when we buried him as we had the captain, in all the solemnity possible in our situation. We had a strong north wind and were detained beating twelve or fifteen days between Cape Mole St. Nicholas and Cape de Maisi with thirty to forty sail of vessels. Spoke Captain Davis of Gloucester and informed him of our loss. That night, the wind as strong as usual, I concluded to bear up and run down the Gulf passage, and in twelve days I was off Havana, and in eight days after, we were cast away on Cape Cod in a violent snow storm on the thirty-first day of December, 1801.' The particulars are these. I had entered the waters of Montaug Point and was within ten or twelve leagues of getting in, when the wind suddenly veered around to the W. N. W., when we hove to, blowing heavy. We lay to three days, and

1 "A schooner, name unknown, commanded by Capt. Gideon Rea, was wrecked on Cape Cod last week, vessel lost, but cargo saved." - Salem Gazette, Jan. 8, 1802. 
when it moderated we made sail and got soundings off the south shoal, ran in by the shoal, wind S. E. About three o'clock in the P. M. the wind came from the east with snow and blew a heavy gale, and we hove to under close reefed foresail. 1:35 A. M. we saw the breakers alongside, when she struck, the sea making a breach over her. We cut away the main mast, the foremast by the violence of the striking breaking in two places. We then beat over the shoal and drove up on the beach but could not discover anything. At 3 A. M. we got on the beach and got up behind a hill, where we trod down the snow sufficiently to walk and to keep ourselves from freezing. At daylight we travelled to the south not knowing what part of the Cape we were on. Having walked about four miles and no prospect of relief, I concluded to return, as we were getting feeble. We walked about a mile when John Low became quite helpless and lost his senses. He had once got into the surf and lost his mittens. I gave 
him mine and placed him up from the surf and left him on the snow helpless. In half an hour more, Peter Woodbury, who was by my side, began to change his color from white to purple and finally fell and could go no farther. He retained his senses when I left him behind. John Porter, ${ }^{1}$ who was with me as well as Cato Gowing, continued walking till we obtained the vessel, having fell down with the intention of giving up as we could. On our arrival at the vessel, we found her keeling over on shore and the tide had left her, so we could get to her side, but we were so exhausted, we could only place ourselves against the gunwale and tumble and crawl on our hands and knees to the cabin, as our clothes on us were frozen and our strength gone. Porter and myself entered one bed and fell asleep, and God only knows whether we should ever have awakened in this world, had not the gale

1 John Porter lived near what is now the Gloucester crossing in Beverly. He was twenty-one years old at the time of the wreck. 
subsided that P. M. at four o'clock, when the inhabitants from Orleans and Chatham discovered our situation from the hills. At all events, the first thing I knew, I was awakened from my stupor by several men hauling and pulling me as though I had been out of my senses, but I stupidly understood them and as I heard afterwards, they were fearful that $I$ was frozen and benumbed, and in consequence, in the loss of my senses. I recollect when I was able to realize my situation, I immediately remembered the situation of my poor shipmates on the beach. Having given the necessary orders to the people, they immediately pursued the direction of the beach, where they soon found the two poor fellows in a senseless state buried in part in the snow. They had struggled and had divested themselves of their boots and hats and mittens and lay perfectly still when found: They were taken up, put into a boat, and carried six miles and the only appearance of life was a slight faint panting at the 
heart. They were placed into the hands of three women who put them on beds, undressed them and commenced an operation of applying blankets and warm flannels, constantly repeating them from 6 P. M. to 1 A. M. the following morning, when Peter Woodbury, ${ }^{1}$ the first who came to, opened his eyes and asked, "Where are we? Whose house am I in ?" Shortly afterwards Low came to, in the same surprise. I learned afterward from the women that the water that came from them was sufficient to pass through two beds on the floor. It seemed on application of the blankets that their whole body had been a frozen body of ice. They revived very soon. The only inconvenience, was the loss of the skin from their faces and hands, and such parts of their bodies as were most exposed. My situation was very bad. Owing to the suffering in my joints and the raw state of my thighs, I

1 Peter Woodbury lived at Beverly Cove. He was afterwards master's mate on the "Constitution," and lost his thumb in the fight with the "Java." 
could not for twelve days walk without the greatest pains, and, consequently, had to sit upon a horse, all the time we were saving the cargo and the wreck. I was detained in Chatham about four weeks. I had written to Boston to the owners of the schooner informing them of our unfortunate situation, but from some etiquette between the underwriters and the owners, neither would answer my letter, consequently, I employed men and saved all the cargo and all the wreck worth saving, and chartered a schooner of Salathall Nicholson, for three hundred dollars to take my cargo on board and forward to Boston. Just as I had accomplished the lading of the cargo, I received a letter from Brook's office, saying they had appointed a Mr. Sears of Chatham to take charge of the business, Mr. Sears called on me and confirmed the statement, but as I had finished all, waiting for wind only, I rendered him my account, with which he was perfectly satisfied, and made no alteration in my arrangements. He im- 
mediately gave me his dispatch and I waited a wind, only Porter and the cook remained with me. Woodbury and Low had recovered and walked home, and I obtained no assistance whatever from any of our crew. Captain John Doane and his amiable wife were like parents to me in my illness and in my business, more attention was impossible to be paid than was by those kind people. The whole of the inhabitants of Chatham seemed to vie with each other to entertain me comfortably and in justice to them, during all the transaction of the shipwreck, no instance of robbery or loss of anything occurred from those people. I wish I could say the same of the Orleans people; they were detected in taking bags of coffee, and actually took one in defiance of the watch. Apparatus of the vessel was stolen, more or less, and deposited in an obscure outbuilding belonging to Mr. Timothy Blank, where it was to lie for division. This fact I detected by taking one of his party in a snowstorm with our effects in his posses- 
sion, and as he candidly confessed the whole plan and who employed him, I had the satisfaction of deducting about $\$ 150$ from Timothy Blank's account, which was very cutting to him, when Mr. Sears settled for me. In regard to Chatham, the manners of the town were similar to all our small towns with the exception of some ancient customs among the young people, and, what was by me at that time disapproved of, - I allude to the free mode of courtship called bundling. While there I was much courted by one of the first young ladies of the place as regards property, but my unfortunate situation would not permit me to enjoy the company of the young people, consequently, the poor girl had to go home alone several evenings, as I wished not to raise any thought of my attention being toward her. We, after settling with Mr. Sears, got a wind and proceeded to Boston. I had Mr. Nicholson passenger. I immediately called on Mr. Francis, who ordered me to call on Mr. Brooks. Having 
called on all, I gave up the vessel and was paid off by Mr. Francis in Boston. My father, who had come up to Boston to take me home, called upon me and took me to his boarding house at William Marshall's, Friday, where I was no sooner known as his son, than all attention was paid, and being Friday night, our table was laid at nine P. M. when the picked bones of a few chickens were placed on the table. My appetite being very keen, I could not indulge in what I saw was so gross an imposition, but declined their proffered service to be helped. I rose at five A. M. and left the house, telling my father I did not choose to pay for starving and I'was going to get something to eat. I accordingly bought me a large loaf of bread and proceeded on board a sloop belonging to Beverly, where they gave me a large bowl of chocolate and I made a comfortable meal. On Saturday at four P. M., my father called me to go home; we arrived at eight P. M., where I found all my family in good health. On 
Monday I proceeded to Boston and settled up all concerns relative to the voyage and returned home on Wednesday.

I shortly looked up a voyage and shipped on board the ship Wells ${ }^{1}$ of Salem, Ezra Smith master, as a light hand. On the day of sailing, our chief officer was taken sick and the second officer promoted chief, and I was made second mate, and for the first time, then seventeen or eighteen years old, paraded the quarter deck. How trifling some of my relations may appear, yet an observing man or a man fond of discipline on board his vessel will see their importance. My having been as a boy with the crew, and they able seamen, for several days they naturally thought they had a chicken to pick, and, as I reflected on all the disadvantages attending me, I came to the resolution to check the first liberty taken; and off Baker's Island, not two hours out, one of the oldest seamen contradicted me in an abrupt manner and significantly; but I first

${ }^{1}$ Ship "Wells," 205 tous, William Gray, owner. 
made him do what I told him, then gave him a few good blows which fully satisfied him that he was to take no liberty with me. We performed our voyage to Hamburg and Russia and returned home, when we sailed for Bremen where we lay in the winter season frozen up till January, when we put to sea with our pilot on board and discharged our pilot at Heligoland. In about seven days we lost Eleazor Giles of fever and buried him at sea. We arrived after about forty-five days at Norfolk, whence we were ordered to Alexandria. Being shorthanded and working hard, I took a severe cold and fever which was very violent and dangerous. Owing to one of the best physicians and Captain Marsh and Captain Roundy and God's blessing, I recovered. The lady I was sick with, was Mrs. Sanger, an amiable woman, and her husband was in affluent circumstances. She did all in her power for my health. We finally sailed for Lisbon with a cargo of wheat and returned via Russia to Salem. Our chief mate was put on 
board another vessel and I was appointed mate. We proceeded to Gotenburg, Copenhagen and Russia, where we made our voyage and returned to Salem. Lying only eight days, we were ordered to Alexandria, our cargo to deliver to Mr. Blank. We arrived in October, discharged, ${ }^{1}$ put the ship in good order and lay till December. In the latter part we received orders to load our ship with flour and be off for Lisbon. In three days we laded and took our boats and hauled down, ice making very fast, and got caught so that it was impracticable to go any farther. As Captain Smith was highly blamed and dismissed the ship on account of it, I feel it my duty to say Captain Smith did all any man could do, and the malicious letters written to Mr. Grey were on account of our not cutting through the ice and taking the ship to Mr. J. D.'s wharf. Mr. J. D. was the cause of it all, and

1 “Ship 'Wells,' Smith, sailed from Alexandria for Lisbon."- Salem Gazette, Feb. 26, 1805. 
at the time Mr. Grey had no better man in his employ.

Captain Smith was ill treated by the whole party. We finally sailed in February for Lisbon, sold our cargo took on board salt and proceeded home, making a bad voyage, we landed at seven P. M. Saw Mr. Grey. ${ }^{1}$ He was very cold to the Captain. Ordered me over very early in the morning. Mr. Grey ordered me on board to await his orders. At eleven A. M. a boat came bringing me a letter from Mr. Grey, saying I must take charge and discharge all hands as the Captain was discharged. I discharged the cargo and paid attention to the vessel, all the time on wages as mate. During this time the young lady I was paying attention to played the coquette by leaving me, but as I was not so far lost in love as to feel the disappointment, I soon got over it and be-

1 William Gray, born in Lynn, June 27, 1750. Removed from Salem to Boston in 1807. Lieutenant-Governor of Massachusetts from 1810 to 1812 inclusive. Died Nov. 3, 1825. 
gan to think of another, and in my next selection I sought one who repaid all loss I could have anticipated. I began soon to fit out the ship for the Mediterranean with a cargo of sugar and coffee and now was hailed first captain, and being only twenty years and six months old, it was thought my prospects were very flattering, but thorns were already in the path of commerce which were quickly to appear. In July 26, 1805, I sailed from Salem for Marseilles, ${ }^{1}$ Leghorn and a market, and my sworn cost of cargo was $\$ 76,000$ and proceeded on about twenty-eight days. When abreast of Tangiers, in the strait, I was captured by the H. B. M. Frigate, Naid, Captain. Thomas Dundas, ${ }^{2}$ eleven days from England, with orders to capture all vessels bound to a French port. I need to say only that we were carried to Gibral-

1 " Ship 'Wells,' Lamson, cleared from Salem for Marsailles." - Salem Gazette, July 26, 1805.

2 The "Naid," 36, Captain, afterwards Vice-Admiral, Sir Thomas Dundas. 
ter, tried and condemned, all but about $\$ 1400$ American produce. The Judge of this court of Admiralty was named Jepthson, the principal prize agent was named Cutworth (he was, for his known rapacity for money, called Cutthroat). The king's fiscal was named Benson, and a more corrupt and worthless Court never got together than when they met. In my instructions from my owners I was to proceed to Leghorn if markets did not suit at Marseilles. ${ }^{1}$ On reading over my instruction they would not admit that clause, neither would Mr. Gavena, the American Consul, interfere. The fact was, it was their custom to meet over their bottle and make up their decisions for the next day, and no observations of counsel was of any

1 Extract from letter of advice of Sept. 30, "Importers should not ship goods they have themselves imported. Court of Admiralty decides with rigor in all cases of continuity of voyage. Vessels should never clear for places in a state of blockade or with an alternate destination." -Salem Gazette, Dec. 8, 1807. 
effect. The plea was, that the mere landing of colonial produce did not neutralize, but that case did not apply to me, as the cargo was all introduced into the United States by other vessels. ${ }^{1}$ When they made that a plea every person in court showed their indignation by rising and leaving Court. Mr. Starks the Swedish Consul, Mr. Drake the Partner in the House of Robert Anderson \& Co. who came out with me, declared that no person could tell on what grounds or for what reasons they had condemned the property; it was an arbitrary and wilful robbery which at that time the British Government countenanced, and Sir William

1 "We understand several decisions in Courts of Admiralty in England have been recently given, that a neutral shall not be allowed to make either a direct or circuitous voyage from an enemy's colony to enemy's country, but where produce was proved to have been bought in the neutral nation, vessels were acquitted." - Salem Gazette, Jan. 24, 1806.

This is the plea that Capt. Lamson urged, that the cargo, whatever its origin, was bought by him in the United States in good faith. 
Scott was a tool of the government at that time, in many of his decisions. ${ }^{1}$

However, in twelve months the property was recovered, but with great loss to Mr. Grey. My being for the first time Captain and having so large a cargo and responsibility wore hard upon me. In four months I was in Salem with an empty ship and a sad tale to my owners. I had not the least doubt my misfortunes would be imputed to my youth and inexperience, and I should lose the confidence of my owner, but on arrival at Boston I proceeded to Salem, called

1 “'The 'Wells,' Lamson, master. This vessel under American colors, with a cargo of sugar, coffee, staves, $\&$ on a voyage from Salem to Marsailles was captured on the ninth of Sept. 1805, by his Majesty's ship 'Naid,' Thomas Dundas, commander, and carried to Gibralter where the usual proceedings were instituted. It appeared that the Judge of the Vice Admiralty court, restored the ship and adventures of Master, mate and sea men and also 5621 pipe staves and thirteen hogsheads of tobacco and condemned the rest of the goods. From which part of sentence claimants appealed. Their Lordships affirmed the sentence of the court below." - Columbian Centinel, Feb. 3, 1808. 
on him, and I suppose he saw the dejection of my spirits, for he encouraged me and told me to keep up good spirits and I should be off again shortly, In about three weeks I sailed again for them for Alexandria ${ }^{1}$ with a half cargo of hemp, candles, sailcloth, and consigned to Lewis Deblois for sale. My order was to take in a cargo of flour and proceed to Hamburg, then occupied by French troops and blockaded by the English cruisers. I had a short passage to Alexandria - say seven days - and on the fifty-sixth day I was captured on the River Elbe just below Cuxhaven. ${ }^{2}$

The particulars were, that when about twenty leagues from the Elbe I was boarded by his Majesty's cruiser, L'Aimable Frig-

1 Alexandria was an important port in 1800, exporting large amounts of wheat and tobacco.

"An Alexandria, Virginia, paper says that in three months 36,000 barrels of flour were inspected at that port and between fifty and one hundred vessels are lying in harbor, waiting to load." - Salem Gazette, Sept. 22, 1797.

2 Cuxhaven, the port of Hamburg. 
ate, ${ }^{1}$ who endorsed my papers and ordered me not to proceed to Hamburg. As my orders from Mr. Grey were to get in if there was any possible chance, although I should meet a cruiser, I informed my crew that I should proceed to Tonningin, and, as the same course for both places was alike for Heligoland, ${ }^{2}$ I ran for it on the same afternoon. At five P. M. I saw the island of Heligoland and a Brig Cruiser standing out. She spoke me, asked where I was bound, and if $I$ had been informed of the blockade. ${ }^{3}$ I replied in the affirmative and proceeded on my course. At nine P. M. a pilot boat came alongside from Heligoland, but he asked me eighty guineas for the pilotage. I offered him five and no more, when he

1 “L'Aimable," 32, Capt. Bolton.

${ }^{2}$ Heligoland was the place from which all vessels entering the Elbe were obliged to take pilots to make their insurance good.

${ }^{3}$ April 1, 1806, Napoleon forced Prussia to close her ports and those of Hanover to the British, and England replied by a blockade of the coast from the Ems to the Elbe. 
left me telling me that I was going to have a gale of wind. I did not then believe it, but sure enough at midnight I had a hard gale of wind. By four A. M. I was under close-reef top-sail and fore-sail, and mizzen stay-sail, and in thirteen fathoms water outside the Vogel sands. At daylight from my top I saw the Island, and as I naturally considered the Brig I spoke was the inner look-out vessel and I had the Elbe open under my lee, I felt sure of evading the blockade, consequently I ran for the red Buoy; but to my astonishment, as I doubled the Buoy, the man at the mast head discovered four sails up the river at anchor. I ran up the top with my glass and discovered that they were men of war. I hauled my ship to, beat her in on eight tacks in their sight till my danger was great in wearing my ship and I started the most of my water and arranged my log to show my distress the night before, and bore up for the squadron. On passing the first ship I was ordered to anchor, but as we were 
under our courses and topsail I told them I would, in hopes as it blew 'so, to pass them, but the Spy sloop of war, which I had to pass very close, fired her waist guns just over our heads. We passed her and two more lying a mile above her and a Cutter, when I thought it best to come to. The gale blowing hard, they did not board me until four in the afternoon when I was requested to go on to the Commodore's ship. On going aboard the Ariadne Frigate, Lord Viscount Falkland, ${ }^{1}$ who was the commander and who was in the Cabin, I was received by the Lieutenant of the Deck, who introduced me to the Cabin. My first salutation was to beg his permission to lay by until the gale abated and I could obtain a pilot for Tonningen. He made no reply, but took my papers and in a haughty manner began to handle them as I stood without his invitation to sit down. I felt disposed to hear him speak and in consequence 1 “Ariadne," 20, Capt. Falkland. Capt. Charles John Viscount Falkland. 
I asked him if he had examined my papers; he replied he believed he should send me to England. I replied, "If you do I have good friends there." He did not like my laconic reply. He says, "You may walk on deck," so I told him I was obliged to him for his politeness. Being nearly eight, the ward room officers (who were perfect gentlemen) invited me below to supper and refreshment, and gave up their accommodations for me and treated me with the greatest urbanity.

I passed the night on board as comfortable as circumstances would admit, and in the morning I called on his Lordship for his determination. He replied that he should send me to England. I told him that he had better have a survey on my ship and look at her shattered state, before he enacted a useless order.

He sent on board his boatswain and carpenter who made a report to suit his Lordship's views when they came back. I told them their report was incorrect, they did 
not state the facts. On the next day, being Sunday, his Lordship concluded to dine in the ward room and telegraphed the Fleet for their Commanders to come on board. I, who was in my common sea dress, a clean check shirt and jacket and trousers, and which had not been thought to disgrace me with the Officers of the ship, was now thought derogatory to his Lordship; consequently, at two P. M. the first Lieutenant called upon me and with as much feeling as a man would have, under such orders from such a despot, told me that his Lordship requested that I would dine that day at a separate table ; that I had an elegant dinner and two servants to attend upon me. I told the Lieutenant on his part to make himself easy. I was sensible that it was not the wish of any officer on board, consequently, I would thank him to give my compliments to Lord Falkland; that I would not partake of a dinner on board his ship; that he now had me in his power and could treat me as a gentleman or as a pris- 
oner of war; my ship was only a detained vessel and I felt myself no doubt of the result, and now, sooner than eat a meal of victuals on board his ship, I would perish on his Quarter Deck. The various Lieutenants and Officers of Marine, repeatedly begged me that I would partake of some refreshment and continually apologized, meaning I should be satisfied that it was Lord Falkland's doings. At four o'clock when at dinner, the officers related my observations to the great man. The first thing I knew, as I was walking the quarter deck, his Lordship came on deck, leaving his dinner and says to me, "Sir, you would like to go on your ship, I suppose." I replied I should like to go where I could be treated like a gentleman. The first news I had, a boat was manned and I was ordered on the "Spy" sloop of war, which was to have convoyed our ship to England. On going on board, the 1st Lieutenant was so grossly intoxicated (in fact there was but one officer, and that the purser, that was fit to be 
on board any decent ship) that I found myself very uncomfortable. I went into the ward room. There were four officers, such as they were. They had not decent provisions upon their table, one solitary mug to drink coffee in was filled and passed around. Their long cruise was their apology, but I was soon convinced of the reasons which were becoming more obvious every moment. I remained and breakfasted the next day, when the same miserable mode of living was shown in their breakfast. During the time I was at the table a boy brought on a dish of stewed porpoise, that some of the officers had stolen from my crew, who had on the passage cured one by smoking it at the Caboose. On an inquiry at the table what dish it was, my boy George Tittle, who was with me on board said, "It was some of our sailors' porpoise." Such a grinning and wry mouths you could hardly imagine. "Take it away, throw it away." It was put off the table. Shortly after I went on deck leaving my 
boy with the ward room boy. He informed me as soon as I was gone up, they fell upon the porpoise and finished it in a twinkling, not leaving any for their boys.

In the forenoon I was walking with the Purser, who appeared to suffer from the unfortunate association with such brutes. The first Lieutenant, about half drunk, was walking on the Larboard side of the deck with the Captain's Clerk, and he repeatedly and loudly observed if he could meet the American frigate Constitution, with his ship and crew, he would capture her. As he frequently turned toward me, I presumed he meant to insult me. I told him if his conversation was addressed to me, he was no gentleman to make use of it in that manner and I hoped that I should meet him shortly in England, where I would call him to account for it. He replied that if I gave him any abuse he would have me confined. I told him it was more than his Master dare do, and I then told him that on my arrival at Yarmouth, I would pub- 
lish and call him out. Captain Hudson of the ship, coming on board after this affair, probably had the relation of my dispute with him. He told the Purser I had served him perfectly right and he commended me for it. I immediately sent a note to Captain Hudson, requesting a separate room from the ward room of his ship, as I would not be associated with part of his officers, and, as my own boy was aboard, I preferred having my provisions sent from my own vessel on board to me. The only favor I requested was his galley. He immediately gave me the Master's room, who was then absent, and from that time, about a week, I had all my provisions of every description sent on board ship. The miserable officers, whom I had no means to rebuke of their impoliteness, would even when I was eating come to my room door and beg for a piece of bread and a glass of brandy, or part of my fowl or whatever I had, the purser excepted. He dined with me on two occasions. I afterwards learned 
that their ship was fitted up, for punishment to officers who had been suspended, and I learned the character of the different officers, and, from her first Lieutenant to carpenter, they had been suspended from larger ships. The purser, though I do not remember his name, was an exception. $\mathrm{He}$ was a young man and was probably as forward in his rank as he would have been on any ship; his responsibility was the same. The only officer whose name I recollect was the drunken first Lieutenant; his name was Yates. At the expiration of a week the "Starling Gun Brig," Lieutenant Napier, arrived and the next day the wind came fair. I was ordered aboard of her and a prize crew was put on board my ship and under convoy was ordered to England.

On board the Starling ${ }^{1}$ I was very comfortable, living and passing my time with Napier. We arrived at Yarmouth and as soon as we arrived I found that the sloop

${ }^{1}$ Brig "Starling," 12, commanded by Lieutenant, afterwards Admiral, Sir Charles. Napier. 
"Spy" had arrived before us, and as the "Starling" was ordered under way immediately again, and as the order of Lord Falkland was that I should not communicate with my officers, until we had gone through with their thirty-two standing interrogatories, ${ }^{1} \mathrm{I}$ was again sent on the "Spy" sloop of war; but as I knew I should be detained not móre than a day on board I felt quite easy, but what was my surprise when I went on board to see First Lieutenant Yates drunk between two of the waist guns and unable to get up, and as many as seven or eight couples fighting. The Admiral's ship was making signals every few minutes to various ships, and the signal or quarter master was looking out and repeatedly calling on the officers to know if it was for their ship; if it had been I know not what would have been the result.

${ }^{1}$ In the Boston Gazette of Aug. 1, 1807, is a copy of the thirty-two "standing interrogatories." They were very searching, and related chiefly to the ownership of the ship and cargo, the origin of the cargo and its destination. 
The Pilot, a decent man, called a North Sea Pilot, was on deck. He told me that he was in actual danger of his life and had been all the cruise, that it was a mercy that they were arrived safe without some disaster, as her cockpit near the magazine was exposed to fire every night, and owing to so much intoxication on board he should write for his discharge.

The Captain of a sloop of war, which lay near us, came on board and not a soul received him. He came on deck, walked below, returned on deck and left the ship. He was an elderly man and felt much mortified by her condition. The following day I landed and at 1 P. M. called on his Majesty's Officers appointed for the investigation of prize cases, and very briefly I told them my story, as well as handed them three affadavits which had been taken on board their ships, they not knowing of it. I drew them up and the three pilots signed them as well as the Heligoland Pilot, and, as they all arrived at Yarmouth, I had them sworn to. 
And with all their watch over me in the Elbe, as to conversation with my officers, I had it every day by letter. The same boat that fetched my provisions invariably brought a letter and carried one to my mate, Mr. Jones, so that when I arrived at Yarmouth, I was as well prepared for my interrogation as though I had lectured my crew for a week. The Board of Commissioners did declare that no case ever came before them where there was such a similarity in the answers to the questions proposed.

On arrival I wrote the House of Bainbridge \& Brown of London and stated all the particulars relating to the voyage and capture, and described the cargo on board. They wrote me to make myself perfectly easy and come up to London as soon as I could and bring up with me samples. On the same day I received a letter from Mr. Lyman our Consul, who had, through Mr. Williams the vice-consul at Yarmouth, been informed of our arrival and detention, 
but as he had learned that I had written Messrs. Bainbridge \& Brown, ${ }^{1}$ he wrote me more as an order to call on him, than as a request; consequently, I did not notice it and I was thankful that I pursued the course I did afterwards, for I was cleared, my papers returned to me, a British license obtained to enter the Port of Hamburg, and all through the influence of Messrs. Bainbridge \& Brown. Whereas more than thirty sail of vessels were there liberated brought in under similar circumstances and were obliged, many of them, to dispose of a part of their cargo to satisfy Mr. Lyman's expenses and commission on amount of cargo for claim and various expenses which took from five to eight hundred pounds to liquidate. My whole expenses including travelling, board, pilot-

1 "Sixty-seven vessels, valued at $\$ 8,000,000$, belonging to the United States have been carried into English ports under the late orders in council. Bainbridge and Brown are the agents for the greater part of this immense American property."-Boston Chronicle, June 13, 1808. 
age, etc. was eighty-three pounds. Shortly after I sailed again for Hamburg ${ }^{1}$ and in three days I entered the Elbe. Off the entrance I was again brought to by the Frigate Ariadne. As I had painted the ship in Yarmouth and as they had parted in the prospect of prize money, they had no idea that the Wells was liberated; consequently, a boat came on board. My mate attended the side. The first Lieutenant came aft and until he came close to me he did not recollect me. His first exclamation was, "How in the name of God came you here again." (By the bye, there had been considerable query on board the Ariadne on account of my telling Lord Falkland I had a good friend in England) and as I now felt disposed to enjoy myself at their expense a little, I asked him if they thought I was jesting when I told them I had good friends in England. He says, "Let me see your papers." He went below into the Cabin. My

${ }^{1}$ Ship “Wells" reported July 9 at Hamburg. - Salem Gazette, Sept. 19, 1806. 
license, which was on vellum paper and in my pocket, was kept from him. I showed him my papers which were as they had been since I was first captured. He would not feel satisfied and repeatedly inquired for some document to show I was liberated from the Port of Yarmouth. As I had availed myself of Sunday for sailing, I did not"pay light money, although the bills were presented Saturday. The only clearance I had was the Vice Consul's account as settled with him, as I had no call at the Custom House, consequently my license was my ostensible paper in the last alternative. He said that he saw nothing to show that I was cleared by proper authority, but he would go on board and if they made a signal I might proceed. But on going aboard they were dispatched back with three more officers, to investigate closely into my being at sea without a proper clearance. After they had been worried and teased until I thought I had sufficiently punished them, I then handed out my license and asked 
them to read it. The first Lieutenant said, "Why did you not show this before?" I observed that he had had his turn of guessing and I should now have mine. To wind up he says, "Well, give us some of your good crackers and we will be off; you have outgeneraled us and I wish you a pleasant voyage."

We made sail and stood into the Elbe when I found three of the British Cruisers. Unfortunately, it blew a gale on my entering the Elbe and when I came up with the squadron, just below Cuxhaven, they ordered me to anchor. I did take in my sail and let go my larboard anchor and ran out forty fathoms. The ship kept drifting. The last, or uppermost of the squadron, as I was drifting by, hailed me and ordered me to let go my second anchor, which I did, but both anchors would not hold me and as I had a hard and fair wind up, I was determined to lose no time. I ordered my cable cut and made sail. I close reefed my main top sail and foresail and mizzen 
staysail and ran for Cuxhaven. Just as I was in the act of grounding my ship the Pilot at Cuxhaven Pier hailed, saying, "We will send you a pilot." I hove all my sail aback with my ship on her heel, and clewed up my sail, running up the river expecting a pilot immediately. I ran for three hours, when, abreast of Glendat, a small town on the river, a boat came alongside with six men who had followed me from Cuxhaven. They all jumped on board. I was in perfect security then. I could put ashore at Glendat or could obtain the Bank of the River, but those pilots began to make confusion. I ordered all but one to their boat, stating I only wanted one pilot, but they took no notice of my order. I called the principal one and told him to take charge and I would pay him the expense of his boat for coming after us. He assented for a time. When they had run me up so far as to enter a number of hard passages in the river, he then takes out a printed document and says, "Unless you sign this I will 
leave your ship." I remonstrated against this arbitrary proceeding, telling him I should not. Finding he was in the act of going away, I took the document, one side being blank, and wrote a correct statement as regarded safety of the ship at Cuxhaven and Glendat, and his producing the Document after running me into danger, my two officers signing as witness to my being compelled to this measure. We arrived at Hamburg at ten o'clock that evening and made fast to the dolphin. I had my cargo landed and my ship ballasted and ready for sea in about three weeks. When ready, to my surprise, a chain was put around the main mast of our vessel and I was summoned to appear before the Honorable Senate of Hamburg, to show cause why salvage should not be allowed to those pilots, who had been silent until that moment. I called on Mr. Forbes, our Consul, requesting him to attend the trial with me and to note the affair.

I appeared at three o'clock at the Senate 
Chamber where sat around elderly gentlemen in black gowns and white wigs. I was immediately called upon the stand and was addressed by the President in English, stating the demand of the pilots. I immediately begged the privilege of making my own statement of facts, as related to the whole circumstance of those pilots coming on board, their conduct on board, my agreement, which they assented to at the time, their imposition afterward which I fully made known to them; but the Board of Pilots, who took up the case in behalf of those on board, were very rash, and told more than fifty lies and had not provided the document which I had written and signed. The Senate having decided in their favor, they proposed that I should allow 16,000 marks, equal to $\$ 5,333$. I ridiculed the idea, and, as my feelings had become wrought to a high pitch, I told the Senate that Hamburg had become notorious among foreigners for the imposition on them imposed by the Blankanese and 
Cuxhaven Pilots and in their transactions with me it was downright intention of robbery, and in the act I did have my coat sleeve partly off, saying, "If you take my ship you shall have my coat also." Then the Senate spoke no more in English but French to Mr. Forbes, and I was dismissed with no conclusion on the business. In three days I was summoned again and demand of eight thousand marks was made. I then told the Senate that I would not make any compromise at all. I would give what I had agreed to give when in the river, and as soon as the wind became fair, so that any ship could proceed to sea, and I found my ship detained under their orders, I would abandon her to them, procure passage for my crew and seek redress from the Government of the United States. I was dismissed again and the next day summoned, when, in a pusillanimous manner, they asked if I would allow three thousand marks. I told them I would not deviate from my former statement. I had 
found that they had seen the document I had written and were convinced that I had been imposed upon, but, as they had had several heavy salvages on ships, they were in hopes to fatten their pilots. On the same evening of my last summons, my Broker, Mr. Glasshoff, called on me and requested me to walk up to his father's who was one of the most eminent attorneys in Hamburg. I went up. He had been in the Senate unknown to me and had heard the merits of my case, and wishing to promote his son's interests, he offered his services to me, saying "Give me one hundred dollars and I will pay your pilotage and expenses and liberate you." At his request, I made a statement of my daily expenses for ship and detriment to the voyage, what my detention had been and, with the documents he procured a settlement. I was cleared, paid my one hundred dollars and got off with less expense than my first agreement and obtained more credit in Hamburg among merchants and Consuls than was properly 
due me, as I had some advice on the subject from Mr. Pitcairn. Shortly a wind came and I proceeded to sea in company with Captain Martin of the George Washington ${ }^{1}$ for Petersburg, Russia. ${ }^{2}$ We arrived safe, and laded our ship with hemp, sailcloth and iron, and sailed the last of August for home. Had a fair passage till, off the nose of Norway, we sprung the head of our foremast.

I put into a small port, Fleceroe, where I fixed masthead and shrouds and sailed the next night. I found the people with little or no bread and the principal living was stock-fish. I was told by the pilot that took me in, that they frequently ate dogs

1 "Narrative of trading and sealing voyage of the 'Huron.' Joel Root, supercargo. I loaded the 'Huron' at Hamburg, and chartered the 'George Washington,' Capt. Martin, to take my own goods to St. Petersburg." - New Haven Hist. Society Papers, p. 171.

The "Wells" and "George Washington" sailed from Hamburg July 9.

2 "At Petersburg, ship 'Wells,' Lamson, Aug. 19, 1806." - Salem Gazette, Oct. 31, 1806. 
when they were pushed for provisions. What led to the remark was one I had on board, which was very fat and vicious and I offered it to him, when he replied, "If I take him, we shall eat him." He took him. What was his fate I know not. We had a hard and tedious passage, constant gales, and ship leaking bad, so we made one hundred and two days from Petersburg and was as short as any who sailed at the same time. ${ }^{1}$

I was at home two months when I was ordered to Savannah, where I loaded with rice and cotton for Copenhagen and Russia. I made an excellent voyage, having sold the rice at eleven cents, the cotton at thirty-seven and a half cents per pound and a fair voyage on my return cargo. On the voyage, while in Russia, I had an opportunity of seeing Alexander the Emperor on several occasions. A Russian vessel returned to Cronstadt from a voyage of

1 “'Ship 'Wells,' Lamson, arrived, ninety-five days from St. Petersburg." - Salem Gazette, Nov. 20, 1806. 
discovery on the North West Coast, and the Emperor appointed a certain day to visit her and examine the various curiosities she had on board. I availed myself of an invitation from a Russian Merchant and accordingly got a convenient seat on the Quarter Deck, where all the various Indian implements of war and destruction were exhibited. The Emperor placed himself by the Captain and appeared to enjoy the visit. He discoursed with several of the sailors, who were all paraded in a line for the review. He appeared at perfect ease and unassuming. He was on board about an hour when he landed and left for St. Petersburg, the men of war firing a salute. I have had various other opportunities of being in his presence at the Marine School and at St. Petersburg. His common dress is a colonel's uniform - green coat and grey riding pantaloons. He takes every means that will become popular to suit the lower classes of people. He has few attendants in his walks and no parade; still 
he knows when he is sought after by foreigners and the multitude. From what I could judge of human nature, I should say he was a man not of very strong mind or of great talents, and as to his figure, he is not ugly and his countenance is quite feminine. When I saw him he had but little beard, and his whiskers were quite small and light color. The character of the Archduke Constantine is quite the reverse of the Emperor. Constantine is a bold, rash head, a strong violent man. He is a very 。 fine figure, nearly seven feet tall and wears a large cocked hat with a high red feather, so that when you meet him walking, he looms up over his attendants as a minister in his pulpit over his hearers. He is fond of great show, and all in the street must give way to his Dukeship and it is a farce to see the confusion and clearing of the sidewalk on his approach, such as the poor women who sell fruit, sitting in the street; if they never stir, the guards upset their establishment to the enjoyment of the multitude who follow or look on. 
The many forms of respect which are paid the Russian Nobility and Gentlemen and their Military and Naval Officers, would hardly be accredited by any one who lives aloof from despotic governments and such, as I hope, we shall never see. As regards the City of St. Petersburg, none in Europe is to be compared to it for the regularity of the buildings and their spacious streets and fine light structure of their houses. The iron bridges, connecting the whole city on a base of seven islands, are neat and fine specimens of architecture and genius. Their marble Church is an elegant and costly building.

Peter the Great, mounted on a horse, erected in bronze, and elevated on a large rock enclosed in the same square with an iron railing, has a noble appearance and the singularity of the monument is, the rock weighs several hundred tons and was transported from the battle ground on which his army gained a great victory over the Swedes. He was on this rock in the night 
of the battle, giving his orders, on account of which it was transported to St. Petersburg. It is now not one half of its former weight owing to cutting into a form to ornament the Square.

Cronstadt, the mole or port our ship lay in, is about thirty miles from St. Petersburg. Our custom is to enter at Cronstadt, deliver our cargo on a lighter and send it to St. Petersburg, the lighter returning from there with our return cargo. We cross on a ferry boat to Baenboom or take a drosky, a small four-wheeled carriage with a kind of seat like a cushion on which we sit astride. They are drawn by two or three horses abreast, and they travel at a rate of ten or twelve miles an hour, and kicking up such a dust you can hardly see before you. I have been completely covered with it to the spoiling of clothes. In regard to Copenhagen, Denmark, I can say but little of it as a place of any great beauty. There are some large and spacious buildings and it has had a great commerce, but it is now 
very much limited owing to the wars in Europe. Elsinore and Gottenburg, which are near, have but little interest to attract the observation of a stranger. Elsinore commands the passage up the Sound on the Danish side and Helsingborg on the Swedish side. Gottenburg is a depot for the introduction of goods for all parts of Sweden. The people are famous for their hospitality to strangers who conduct themselves with propriety. I can attest to that myself. When I was only mate of a ship I received the politest attention from some of the first characters in the city, and that without any introduction of my Captain, who rather envied it. To return to employment with the ship. Having laid at home some time Mr. Grey ordered me to purchase about three thousand quintals of fish, and fill up with coffee and sugar and proceed to Alicante and a market in the Mediterranean. ${ }^{1}$

1 “'Ship 'Wells,' Lamson, cleared from Salem for Alicante." - Salem Gazette, Dec. 4, 1807. Ten days be- 
I consequently made all dispatch and completed my lading and sailed about the fourth of December, 1807, having fine wind. I passed Gibraltar in twenty-five days, and on the next day spoke Captain John Holman of Salem, and Captain Ross of Newburyport; both told me that their papers were indorsed by the English cruisers then cruising off Cape Palos.

I immediately obtained all the information from them I could, how the English vessels cruised, what time they were off Alicante and what time they stood off. As Captains Holman and Ross's accounts agreed, although several hours' difference in my speaking them, I thought I would evade them. I had a strong wind, and by carrying sail I could reach Alicante by daylight, at the time I supposed the Cruiser would be off Majorca. I consequently made all sail at midnight. I went around Cape de Palos within pistol shot, blowing fore the Non-importation Bill went into effect and eighteen days before the embargo. 
hard, and at daylight was within eight or nine miles of Alicante, when the wind veered off shore, and directly I saw a Frigate and Brig, men of war, under my lee. I tacked ship and stood toward Cape Palos again in hopes they would not notice me, but directly the brig made all sail in pursuit, and by nine A. M. was alongside and sent his boat on board. She was the Grasshopper, ${ }^{1}$ Captain Searle. He informed me that every port in the Mediterranean was under blockade and I must proceed to Gibraltar, Malta or England. ${ }^{2}$ Under these circumstances I went on board the Brig and stated to Captain Searle that my cargo was of a perishable nature, and as such was not included as coming from an enemy's port. I requested that he would endorse on my papers a privilege of pro-

1 "Grasshopper," 12, Commander, afterwards Rear Admiral Thomas Searles.

2 That is, to some English port. Orders in Council of Nov. 11, 1807, no trade with the Continent except through English ports. 
ceeding. Then he stated that his orders were positive, and as a gentleman, knowing the rascality of the British Government, he politely showed me his printed orders. I could do no more. The wind came to the eastward. In two days I was back to Gibraltar, where I found about fifty sail of my countrymen in the same anxious state. I applied to the Judge of the Board of Admiralty for a license to proceed to Sicily, and I obtained it and was getting ready to go aboard, having sold my sugar and coffee and landed it.

A few days before I was ready to sail a terrible gale ${ }^{1}$ blew from the East, and, as the Bay was full of vessels, the destruction was horrible to lives and property. No less

1 “Arrived ship 'Rachel' from Gibralter. The late gale was said to be almost the severest ever known there. The 'Mary' of Boston, the 'Two Brothers,' the 'Minerva' and three others were stranded. The 'Venus' of New York and the 'Wells' of Salem were driven to sea. At Algesiras thirty-six vessels were driven ashore." Salem Gazette, March 31, 1808. 
than forty sail were lost, sunk, upset, driven ashore and foundered at sea. I rode out the gale two days when one cable parted and we were obliged to cut the other. I went to sea and lay all night under mizzen staysail in the Gut. At daybreak finding myself close on Tarriffa shoals and blowing a hurricane, I loosed the yard arm of my foretopsails and wore, about a pistol shot from the breakers. As myself and crew were nearly exhausted, my lower rigging one half cut away and no anchor, I put up my helm and ran out the straits and luffed round Cape Spartel, laid to under short sail and put the ship to rights. In two days the gale subsided and the wind came to the West. I made all sail. An English seventyfour which was abeam of me and bound to the straits, and which I came within musket shot of and which I made signals of distress to, would take no notice of us. Knowing now my risk of the Algesiras privateers, I immediately hauled into Tangiers roads, and lay my ship to, till three o'clock in the 
afternoon. It appeared they had signaled us on the opposite side, so that at three, when I made sail, I could number eleven privateers watching for us; nine were small and two were large. I called my officers and men and told them our fate, and that our only chance was to prevent our yards and booms with braces, and carry sail and take our chances, not minding their shots. We out all sail and, blowing heavy, she troubled the watch and the man at the helm a great deal. Very shortly two of them were alongside within hail, firing and hullooing. I took no notice of them and in a few moments nine of them fell astern, all firing when they could. Our prospect now looked fair and, when in an hour I expected to be clear, what was my mortification to find the wind die and my rate of going reduced to about five knots. The two large privateers were ahead and prepared for me, and so uneasy when they thought that I should pass them, that they placed themselves on each bow and boarded me all standing, 
with grapplings, and broke off my fore and main yards in the slings. In one minute one hundred were on board. I ordered all my men below as they boarded and threw myself into the cabin till the first onset was over, but in a moment my cabin was filled with as motley a set of villains as ever manned a vessel. Such was the confusion with pistols at my head and cutlasses waving and threatening instant death if $I$ did not give up my papers. I told them when they got my vessel in, the proper authorities should have them. Finding them savage, I told them if there was a Captain of any of the privateers among them who would clear the cabin, and sit down and give me a receipt for my papers, I would deliver them, consequently one of the New Orleans creoles said he was Captain, and cleared the cabin. I gave him a few of the papers and took his receipt. They towed the ship into Algesiras ${ }^{1}$ and secured her at anchor,

1 “'Reported at Algesiras, ship 'Wells' of Salem, Feb. 20." - Salem Gazette, April 5, 1808. 
where I found many in the same situation. I remained quiet till such a time as my fish began to perish, when I applied to the Government for liberty to sell my cargo and deposit the proceeds in an independant person's hands till we knew the result of the Court. At this time Bonaparte ${ }^{1}$ was in Madrid, the Spaniards had no government, and the government at Madrid was not organized. Our case was suspended, and in a few days the French had to fly Madrid, a Cortes insurrection broke out, and tribunal after tribunal was created, one acquitting and one condemning and in fact no positive decision could take place. I consented to compromise with the captors. ${ }^{2}$ I wrote R. M. Meade of Cadiz to

${ }^{1}$ Joseph Bonaparte, appointed by Napoleon, King of Spain and the Indies, June 15, 1808. Obliged to evacuate Madrid, Aug. 1, 1808. French reëntered Madrid, Dec 3, 1808.

2 "Vessels detained and condemned at Algesiras since Jan. 30, 1808, 'Wells,' Lamson and many others."Salem Gazette, Sept. 27, 1808. Condemned under the Milan Decree of Dec. 16, 1807. 
know whether he would be surety for my bond for ship and balance of cargo. He complied and I closed with the captors at the sum of five thousand dollars. I immediately went on by land to Cadiz, saw Mr. Meade and settled to his satisfaction, and returned to Algesiras when I shipped my crew and proceeded to Alicante. On my arrival I wrote to Messrs. Brice, Tupper \& Co. having found that they had remitted a sum of money to England which I was to have drawn from them when I left home, but being detained nine months they had disposed of it. Freight being high, I had concluded with Messrs. Bushnell \& Co. to take a freight for them to Dublin in case I found no funds in Valencia. During three days I waited for my answer. I was, through the politeness of Mr. Bushnell, introduced into the castle on the hill, which is noted for its uncommon defense made by the English a number of years ago. As the rock is of soft substance, something like Portland stone, 
it is easy to excavate. The Spaniards had begun to mine at the foot of the hill and had excavated a large place nearly perpendicular with the center of the fort, and, having placed in it a large quantity of powder, they sprung the mine, and singular as it may appear, the eruption severed half the hill, destroying most of the garrison. From the hill you have a fine view of the country and of the bay of Alicante. On the return of post I commenced lading for Dublin and in six days I sailed. In eight days I was in Gibraltar and proceeded in my boat for Algesiras where I found my companions still detained. Captain Foster of Boston and some others were adopting the mode I took, bonding their vessels. Mr. R. Meade had intimated to Captain Foster that I was headstrong in my business, and he hoped he would not pursue the plan I had. But when Mr. Meade had heard, by my letters to him overland, of the high freights I had obtained, he wrote me by way of Algeciras, 
which letters I took up on my arrival, and complimented me highly on my success and said a great deal of my judgement. As I had on the same day seen Captain Foster's letter, which Meade wrote him of me, I felt no way pleased with him. I wrote him on my business, and that very brief, and left that night for Gibraltar. Having a wind the next day, I sailed for Dublin and after a short passage of thirteen days I arrived. We had a severe snow storm two days before I arrived in the Irish channel. We discharged part of our cargo in Dublin and proceeded to Newry. We anchored our ship at Warin's point and discharged in lighters which took the cargo to Newry about four miles. I was much surprised at the poverty of the lower orders of Irish in that quarter. I walked to Newry repeatedly and visited their hovels on the road, from curiosity to observe their mode of living, which was this. Their hut had one room only on the floor, and one side was occupied with a pig and cow if they had one, 
the other was occupied with the family lying on straw for their beds. The only food was potatoes and those boiled with one or two herring, if they could get them, and yet their children, half clothed and barefooted, looked rosy and rugged. It was truly affecting to hear their women relate their hardships. I generally gave them a trifle in money which seemed to overcome them in expressing their gratitude.

While lying at Newry I was offered a very high freight to go to Archangel with a great profit to myself. I was on the eve of concluding when I wrote Messrs. Bainbridge \& Brown for their advice. I proposed to them the same voyage, making use of $\mathrm{Mr}$. Grey's funds in their hands. But Mr. Story of Boston being in Liverpool ${ }^{1}$ with an investment of goods of $\$ 140,000$ pro-

1 "On April 28, 1808, there was not in Liverpool a vessel from Boston or New York. Those who have anything to do with freight or charter are absolutely insolent in their demands, $£ 2000$ for a ship of 199 tons to Lisbon and back." - New York Evening Post, June 28, 1808. 
perty of Mr. Grey, and, since, owing to the long embargo ${ }^{1}$ no American vessel was in England which could take his goods, and since shipping on an English vessel would subject his vessel to ten per cent extra as well as a high freight, consequently, he wrote me to come to Liverpool and take Story's goods. I immediately ballasted and sailed for Liverpool, ${ }^{2}$ and repairing my ship in the dry dock, took the cargo and filled up with salt and crates, and took twelve passengers at the rate of thirty guineas a head. We sailed and arrived in Boston $^{3}$ in forty-seven days, say about the 4th of June, and lay till the 10th ${ }^{4}$ before

${ }^{1}$ Embargo passed Dec. 22, 1807, no United States vessel allowed to leave port without giving bond that her cargo would be landed in the United States. Lasted until March, 1809.

2 “'At Liverpool, April 12, ship 'Wells,' Lamson, for Boston in six days." - Columbian Centinel, May 31, 1809.

3 “'Arrived ship 'Wells,'Lamson, forty-seven days. To William Gray. Dry goods, salt and coals. Passenger, Mr. Story." - Columbian Centinel, June 5, 1809.

${ }^{4}$ On the nineteenth of April, the Non-intercourse Act 
we came to an entry, as no vessel from England was permitted to enter until that period. We docked at Charlestown and hauled up the ship. We lay quiet about two months when we loaded the ship for St. Sebastian ${ }^{1}$ with cotton, sugar, indigo and logwood. I had a fine passage of twenty-seven days out. Off Cape Antonio near Bilboa I was chased by a British Frigate. Being near night, I got clear in a squall by wearing the ship, and next day I entered St. Sebastian blowing a gale of wind. I lay four days in quarantine and got a clean bill of health and hauled into the mole. The place was occupied by French troops and had a French government. The second day after I entered the mole it was hinted to me by Richard Bir-

was suspended by proclamation of the President, so far as it related to England. June 10 was the date set when vessels from England might enter.

1 Capt. Lamson has made a mistake here. He must have sailed for St. Sebastian in August, 1810, and not 1809, as shown by extracts from papers quoted below. 
mingham, my merchant, that the American property was in jeopardy. I, consequently, with Augustus Aspinwall made an arrangement with the house of De Taslet \& Co. to cover our property by a fictitious sale, which they did at three per cent on the property saved. I immediately began discharging, though raining and blowing hard, to the astonishment of all the Americans there, and had got one half of my cargo on shore when every vessel and cargo the next day was sequestered by order of Napoleon, ${ }^{1}$ and guards placed on board all our vessels. $^{2}$ I saved one fourth of my adventure, which netted me $\$ 1900 .^{3}$ As the orders in

${ }^{1}$ Confiscated under the Rambouillet Decree of March 23, 1810, not published until May 14, 1810.

2 "French paper of Nov. 27 states, advertised to be sold on Dec. 15, 1810 at Bayonne, the 'Wells' and many others. The 'Wells' is owned by his honor Lt. Gov. Gray."-Columbian Centinel, Jan. 19, 1811.

3 "What magnanimity and loving proof of French kindness. Ship 'Wells,' bought by a carpenter for sake of her spars, brought 4500 francs, one thousand dollars; Owned by Hon. William Gray of Boston. It appears that 
Council were enforced, I availed myself of sending shipments by fast sailing schooners to New York, which all arrived safe and paid me a handsome profit. I remained in

when the American vessels were sold by order of Bonaparte, the French privateers and merchants bought all that would sail fast, or might serve for coasting trade, after the Emperor himself had taken without form of sale, such as were best fitted for cruisers. The residue not being wanted by the Master or his servants were politely left for American bidders."-Columbian Centinel, Feb. 29, 1811.

The Federalist papers had evidently not forgiven Mr. William Gray for his desertion of their party.

Capt. Lamson made a claim on the French Government for the loss of his adventure on the "Wells."

The profits as well as the dangers attending trade at this time are shown by the prices the goods sold for in France as compared with their original cost. Cotton costing fifteen cents in America sold at auction in France at one dollar a pound. Rum bought in America at sixtyseven cents a gallon, brought three dollars a gallon in France. The whole adventure, which stood Capt. Lamson as landed in France $\$ 1258$, including freight and insurance, sold at $\$ 4218$ at the auction held by order of the court. The danger of the trade is shown by the insurance, which was twenty per cent.

(Captain Lamson, Private Papers.) 
France and Spain from December 12th, 1810 until February, 1811, when I closed my business and embarked on the ship Commodore Rogers, Captain Shaler, for New York, and, after a disagreeable passage of forty-four days, we arrived in New York where I remained a few days and went home to Beverly. ${ }^{1}$ I remained at home a few weeks and, as Mr. Gray had no ship at that moment, I took charge of the schooner Angler $^{2}$ for Messrs. Leach, Stephen Thorndike \& Kilham and made a good voyage for them to Archangel, gone about four months. ${ }^{3}$

1 “Ship 'Commodore Rogers,' Shaler, forty-one days from Bayonne, arrived in New York. Passenger Z. G. Lamson and thirty American sea men from condemned vessels. Dec. 15, at Bayonne took place the sale of nineteen American vessels, the 'Wells' and eighteen others. Total sale realized $\$ 50,900 . "$ - Columbian Centinel, Feb. 16, 1811.

${ }^{2}$ Schooner "Angler," 96 tons, built in 1803. Owned by Thomas Stevens, William Leach and Abraham Kilham of Beverly.

3 " To-day cleared schooner 'Angler,' Lamson, for Archangel." - Salem Gazette, May 3, 1811. 
Archangel at that time was the only free port in Russia. The difficulty with the continental powers in regard to the passage of Elsinore made it unsafe to pass that way for St. Petersburg. The produce at Archangel was transported to Moscow for sale; and the fire at Moscow our merchants too well remembered who had their goods shipped there, as it was a total loss to many. Fortunately I closed my voyage and was almost the only one who got away with their funds.

Archangel was a busy place at that time and by having an army of ten thousand men stationed there they kept the place quite lively. The disposition of the merchants was to enjoy themselves, so that with some, the day and night was hardly distinguishable. I was quite tired of the place, being all the time employed, and, it being all daylight I had but little sleep and till I doubled the North Cape and got to the South and West, I did not feel myself in my proper element. I had about a seventy 
days passage home where we arrived safe in October, 1811, and discharged the vessel. ${ }^{1}$ As Mr. Grey still was willing, I took charge of the Sally ${ }^{2}$ belonging to the same owners, and proceeded to Corunna. ${ }^{3}$ I had a cargo of pepper, fish and sundries. I sold about $\$ 10,000$ worth at Corunna and proceeded to Gibraltar, where I could not sell. I proceeded next to Palma on the Island of Majorica. There after a long time, say ten days, I sold the cargo to a Swedish house who likewise employed my vessel to take it to Alicante. I loaded my vessel with wine and fruit, and took my pepper on deck to Alicante and obtained about $\$ 1500$ for the job, which was no inconvenience to my voyage. I sailed from

1 “' Yesterday arrived in Beverly, schooner 'Angler,' Lamson. Long passage from 'Archangle." - Salem Gazette, Oct. 25, 1811.

${ }^{2}$ Schooner "Sally," 73 tons, built in 1798, registered in 1811 as owned by Thomas Stevens, Nicholas Thorndike, William Leach and Abraham Kilham.

3 “ Cleared 'Sally,' Lamson, for Corunna."-Salem . Gazette, Dec. 13, 1811. 
Alicante for Gibralter, and off Almeria near Cape de Gata, during a calm, two French Privateers rowed up alongside, but a display of hats on hand spikes and sticks, and pointing seven guns on a side during the time they were coming, scared them off. We sat our pennant, and out all light sails and chased them, with a light breeze which sprung up about then. I was so sure I was gone that I had distributed all my money in gold among my crew to secure around their bodies.

Just as I was giving up chase a frigate hove in sight, and as we sailed quick I availed myself of her convoy in, and arrived in Gibraltar but a few hours after her, where I found another schooner of my owner with a similar cargo, but making a miserable voyage. I took on board the spices I left with Horatio Sprague, Esquire, and proceeded home and a few days out, in Longitude 14 West, at daylight in the morning, I think about the tenth of May, I was close on board a French squadron, two 
frigates and a corvette. ${ }^{1}$ I was boarded and ordered on board. After an examination I was ordered to take my things on board that they might sink my vessel. I repaired on board, took my money and things in part. The Lieutenant on board had stolen my watch, and my mate, Edward Chap-

1 "Capt. Mather of the ship 'Active' reports that the ship 'Mercury' and the brigs 'Pazzo' and 'Happy Couple' were taken and burned by a French squadron, May 3. He was boarded by the same squadron, commanded by Commodore Feretier, detained sixteen hours and had putaboard of him seventeen seamen, the crews of the vessels burned. May 6, latitude 35-30 saw the wreck of the schooner 'Sally' from Majorca, which they had scuttled May 2." - Salem Gazette, June 19, 1812.

"On the ninth of Jan. 1812 the two French 40 gun frigates 'Arienne' and 'Andromaque' and the 16 gun brig 'Mamelouke' under orders of Commodore Martin le Feretier, sailed from France on a cruise. The French frigates saon commenced their depredations on commerce, plundering and destroying not only English vessels, but those of Spain, Portugal and the United States. The 74 gun ship 'Northumberland,' Capt. Hotham, was sent in pursuit and on May 22, 1812, intercepted them on their return to Nantes and drove them ashore where they were destroyed." - James, Naval History, vol. vi, p. 48. 
man, who was a worthy man, took out of his pocket my spy-glass he had stolen, - so my mate informed me. I saw on board the Frigate, my own liquors, wines and fruit drank by those French officers and not one of the many American officers could obtain the least favor on board. The Commodore, who was a dirty fellow and a great sloven, promised me on his word of honor to restore me my money and give me the first vessel he captured, to take me home with many of my countrymen he had on board. As an especial favor, Robert Blair of Philadelphia and myself, were the only Americans who lived aft. He took three vessels but always refused to let me go, until I refused to ask him, and indeed, I gave up any idea of going until, just before he got off Cape Catigat, he captured a Merchant ${ }^{1}$ English vessel and sent me

1 "They [the squadron of Feretier] had destroyed thirty-six vessels, taking the most valuable part of their cargoes and one vessel they sent as a cartel to England with about two hundred prisoners." - Naval Chronicles, 1812, p. 310. Extract from repori of Capt. Hotham. 
on board with one hundred and forty Englishmen who were prisoners he had taken. He refused me my money and everything I asked him. After I went on board the Cartel I sat down and wrote him a letter, in as polite terms as I was able, stating his pledged honor and the pleasure he must have in reflecting that he had turned me afloat without a dollar, and he holding illegally $\$ 1500$ of my own, which my accounts showed as mine. He, on receipt of this, sent me in a pitiful manner $\$ 200$. One thing, - about a week after I was taken, I recovered my spy-glass, although ruined by the robbery of the principal glass. In fact, the most that could be said of the flying French squadron, is that they were composed of as great a set of blackguards and dirty fellows as ever could get on board a ship. That relates to the Commodore's ship and he was a disgrace to the French Navy. I understood that on his losing all his ships off Nantes, because he was chased by an English seventy-four, that he was 
sentenced to death, but his life was given him finally by Napoleon. The treatment Americans received on board was horrible. Three masters and five men died, owing to the rough treatment, and no reasons assigned by those rough villains. On leaving the squadron next day, we fell in with two English frigates who impressed from the Cartel about twenty of our seamen and went, as they said, in pursuit of the French ships. I arrived in England, and four days afterwards I was in Plymouth, quite unwell from what I had suffered on board those ships. After I had recruited, I embarked on board the ship Acasta of New Bedford, Captain Lewis, and sailed from Plymouth for Boston, and off Grand Bank Captain Lewis pulled upa hogshead of rum. He gave his mate a ten gallon keg and on the same night, he having fifty sailors between decks, they stole it from the mate. The next day a general search was made but it could not be found on board. Two nights afterwards, about midnight, the cry of 
murder was heard between decks. We passengers were between decks and such a scene we do not often see as her decks presented. As many as six or eight couples were fighting between decks and it appeared that they were killing each other below with knives. I advised Captain Lewis to draw a rope across the deck by the mainmast and threaten death to any one who came abaft. We all agreed to support him and by adopting this course we kept the quarter deck clear, and by daylight we discovered a large sail which we took to be a man of war. I advised speaking her and putting the principals on board. At ten A. M. spoke her and to our astonishment, we were informed of the American government's declaring war, ${ }^{1}$ and we were a prize to her. She proved to be the English fifty gun ship Antelope commanded by Captain Carpenter, bearing Admiral Duckworths flag. ${ }^{2}$ I was detained on board the

1 War declared June 18, 1812.

${ }^{2}$ Admiral Sir John Duckworth, best known for his rather inglorious passage of the Dardanelles in 1807. 
ship, where my treatment was such as to take away the idea of my being a prisoner. ${ }^{1}$ I must say Captain Carpenter and his officers, both marine and navy and petty officers, vied with each other to entertain me and make me comfortable on board. I remained on board twenty days when we arrived at St. John. Captain Carpenter introduced me to the Admiral, and everything consistent with an enemy was offered to facilitate my passage home and my comfort there. To the credit of the 3rd Lord Mandeville, the Duke of Manchester's son, a lad of fifteen years, a midshipman on board the Antelope, I cannot omit this trait in his character. ${ }^{2}$ When he came on shore he offered me half the money he had by him if I wanted it. I politely refused it,

1 “Ship 'Acasta,' Capt. Lewis of New Bedford, reported captured by the "Antelope." - Columbian Centinel, July 10, 1812.

${ }^{2}$ It was the custom of the Manchester family from an early date to keep one or more members in the English navy, and several rose to high distinction. 
but I felt the greatest attachment to him from the manner it was offered. The tears stood in his eyes. He had been in my room repeatedly on board, and, as he was studying the various branches of navigation under the care of Mr. Holbrook, the master, he would apply to me frequently by questions relating to certain rules, which I took pleasure in communicating to him. After remaining three weeks in St. John, my friend Pyem Lovett and myself bought a small schooner, which we sold out to several, whom the Admiral permitted to go home. Our vessel cost us $\$ 1800$ and sold for $\$ 400$ in Boston. We had about fourteen days passage and had some of the best young men in Philadelphia with us. We were about eighteen in number on board. Part did not pay passage. We had several who were disagreeable on board but of Lovett and myself they kept clear, as we each took charge daily in our turn. We arrived in Boston, when each of us proceeded direct to our homes to the great joy 
of our friends who had not heard of our capture. War was then raging and privateering was the order of the day, but my friends and that section of the country I lived in, ${ }^{1}$ did not approve of it, consequently I did not partake of it. I remained at home about six months occupied in various pursuits, principally in gardening until I was tired, when I bought part of the Brig Isabel, a whitewashed prize brig and took a Spaniard as Captain and a Spanish crew, and a cargo of lumber for St. Jago and proceeded to sea. Three days after the Chesapeake was captured. ${ }^{2}$ On the second night out, off the South shoals, was boarded by the English Privateer Brig, Sir John Sherbrooke, ${ }^{3}$ who was very particular in the examination of papers. After I was

1 It was to the war itself, rather than privateering, that the section of the country in which Capt. Lamson lived was opposed.

2 June 1, 1813.

3 English privateer brig, "Sir John Sherbrooke," 10 guns and 40 men, afterwards captured by the American privateer, "Saucy Jack." 
satisfied that he was an English Cruiser I showed him my license, and he then was quite easy, but privateer man like, he stole a sheep, a ham and as many fowls as he could carry with him. ${ }^{1}$ The Lieutenant was named Freeman who stole them. He was a brother of the Captain. We proceeded on and arrived at St. Jago in twentythree days. I then sold my cargo and loaded a vessel under Spanish colors, ${ }^{2}$ commanded by Captain Burke of Charlston, where he safely arrived. I laded the Isabel for London on freight and sailed in August, 1813, and had a blustering passage. Knowing that the English examined

1 Capt. Lamson fared better than the ship "Ariadne" of New Bedford. This vessel was boarded April 12, 1812, by the "Sir John Sherbrooke," part of her cargo taken, her papers and British license burned and nine of her crew impressed.

2 "The British government has issued an order that condemned American vessels can be bought by Spaniards and put under the Spanish flag. You may expect to see many of your vessels suddenly change their colors." Letter from Cadiz, Niles Register, vol. 4,.p. 107. 
very closely all vessels under the Spanish flag, I made sale of the Brig to two different persons in St. Jago, so she appeared to be long owned in Cuba. The Commandante of Marine was well acquainted in Cuba. He had lived at Pensacola and he furnished me with a Spanish name and Spanish papers of naturalization and called me Pedro Blanco, which name I passed by during all the war. On leaving Cuba I beat up and passed through the French Keys. I ran for Halifax to clear the British cruisers and when off Halifax, say eight leagues, I was spoken by an English seventy-four, a frigate and a schooner in company. It being foggy shortly after, I bore up, ran down the coast twelve leagues to the east of Halifax. I then got wood and water which we were short of and discovered the treachery of the inhabitants, as I believe they sent on to Halifax to give information of me, but I sailed just at night, to the surprise of those Tory and Irish beggars of that place. Three days after I 
fell in with an American Cruiser Privateer, the "Elbridge Gerry" of New York, commanded by Captain Turner. ${ }^{1} \mathrm{He}$ was an old acquaintance of mine, had lived on board my ship three years before in France, but I had so disguised myself by my mustaches and beard and an old dress of my boatswain's, and not allowing any English to be spoken, and having rubbed my cabin over with garlic, and all being natural Spaniards but myself, and my speaking Spanish, that they after a search of three hours, left us, supposing as they said, "He is a real Spaniard." In justice to Turner, I will say he behaved well. He took no other liberty on board than his duty required. The next day at night about ten o'clock, being about as I supposed thirty to forty leagues to the East of Turner, at ten o'clock in the evening I fell in with an English Frigate called

1 “The 'Elbridge Gerry,'schooner, 160 tons, 14 guns, Capt. Turner, captured by H. B. M. Frigate 'Crescent' off Cape Raw, Sept. 18, 1813." - Emmons, Navy of the United States. 
the Crescent, ${ }^{1}$ Captain Somerville. They boarded us, sent a Lieutenant who was a Genoese and spoke the Spanish language. He overhauled the crew. I passed unnoticed by him and he looked over the Log. He saw we were boarded by Turner. He took his minutes and went on board and I was informed captured the E. Gerry. The next day, after a short chase, we proceeded on for England and in a few days to the east of the Bank fell in with a fleet of sixty sail, from Quebec for England under the Rota Frigate ${ }^{2}$ and a sloop of war Brig. The Brig spoke us, ordered us alongside the Frigate and the Captain to go on board with his Log book. He went on board where he was treated politely by Captain Somerville and obtained the fleet's instructions and signals. We kept with the fleet until nearly up into Cape Clear and then went ahead. I left them and proceeded for

1 "Crescent," 36, Capt. Somerville.

2 The "Rota," 38, was a Danish vessel captured by the English and commanded by Capt. Somerville. 
Portsmouth, and speaking with another cruiser only, I arrived off Portsmouth and from thence off Dover, when I took a Pilot and anchored on the downs at eight o'clock in the evening. We parted, or cut our cable as the Pilot would have it, as he cut it after it had parted. We ran off Ramsgate and brought to with our small bower. The next morning a boat with cable, anchor and buoy rope came alongside. We took it on board and lay wind bound five days, when we got under way and proceeded for London, beating up the river with a Pilot and two Custom House officers on board and, although they were on the alert, not one knew I spoke English and the most laughable yarn was, when I arrived at Graves End, one of the officers went on shore to bespeak me a breakfast and a passage for London, but rogue like, he calls for liquor to treat a number of his friends and told the bar-keeper that the Spaniard upstairs will pay you for all. The girl who attended the coffee room and fetched my breakfast par- 
took of the same disease. When I had breakfasted and found the stage at the door, I wished to know in broken English what I was to pay. She kindly told me £2 6d. I saw eighteen pence paid by one gentleman who breakfasted as I had, and, as there was no time to parley, I told her in good English that she ought to loose her place for attempting to impose on a traveller. I gave her eighteen pence, when, as though struck dumb, she courtseyed and asked me to remember the maid. I told her I should always remember her when I passed that way. On mounting the coach the barkeeper came out with a demand on account of the officer but I gave him the Spanish reply "no entiendo." The gentleman on the stage, supposing I was foreign, and being told I was supercargo of a Spanish Brig from the West Indies, would not suffer me to pay, but on the contrary took my money, paid all my travelling fare and gave me my change regularly as he paid. I could hardly refrain from laughing when they 
would try to make me understand their money. We arrived in London. Just before we got to the Bank of England I stopped the coachman and got down in the street and travelled to the Virginia Hotel. With my mustachios, long beard under the chin and much sunburn, nobody in the Hotel knew me, although I was an old boarder. Then, after a while, I asked if I could have lodging. They replied they would see but looked quite hard at me. Finally, I made myself known to them, when the best thing they had was for me. I saw a gentleman reading a paper in the room who had a genteel appearance. On enquiring, I found him an American. I showed him my letters, and found him acquainted with Mr. Bainbridge, and then I opened my business to him. He was glad of my acquaintance, and we the next morning called on Messrs. Bainbridge and made arrangements for selling our cargo. I was introduced by the name of White, ${ }^{1}$ and $\mathrm{Mr}$.

${ }^{1}$ Pedro Blanco $=$ Peter White . 
Bainbridge, whom I had been intimate with, did not know me. I remained with him for a week or ten days, when I was disposed to make myself known to him. Just as we were going to drive, I asked him if it was possible I was so altered he did not know me. He said he had doubts in his mind whether he had not seen me before, but could not recollect. My voice was familiar, and that was all. I mentioned Lamson and the ship Wells, when he was quite astonished as well as diverted, and immediately introduced me to his wife as an old friend. We dined and passed many jokes on the intrigue. We were obliged to maneuver in consequence of the war. I discharged my vessel, coppered her and got ready to lade when Messrs. Bainbridge, Ryly \& Young, John Gosler and myself, agreed that I should take about $\$ 12,000$ worth of India goods and a credit on Trinidad for thirty thousand more and proceed to the Oronoko for a cargo of hides and indigo, he giving me a full commission, 
$£ 3000$ for my Brig and 10 per cent for myself. ${ }^{1}$ But before sailing, to show the rascality of the Spaniards I had on board, when they had the chance, I will relate the conduct of them. My mate and eight of my crew never had, during the coppering of my vessel, paid any attention, but were continually gone. I had complained to them of their conduct. The mate as Principal, with the crew, called on the Consul General and informed him I was an American owner of the vessel, and that she was not Spanish. The Consul General wrote a letter to the Vice Consul, who informed me of it. I directed the vice consul to request him to see her papers and call on Messrs. Bainbridge \& Brown, and he would be satisfied. He was satisfied, and gave the man no hearing. They called on the Spanish minister, who wrote the Consul General and received the Consul General's reply, when the minister sent me a

1 Primage was a sum over and above the freight, paid the captain of a vessel for looking after the cargo. 
note, with an order to imprison them if they gave me any trouble, and to show his regard for Messrs. Bainbridge \& Brown, he sent me a general Passport gratis, to travel in all parts of the world as a Spanish subject. In the meantime I shipped a mate and as many men to come on board the day I sailed, and just as I was dispatching the Brig, the villains came aboard to go the voyage. I turned them all into their boats, though they begged with all submission to go, but I had my complement, consequently they were left behind and knew that I did not go down in my Brig. I had by three o'clock no less than four or five lawyer's letters in the house for me, but I left them there and proceeded for Gravesend, and it being Sunday, I went down the river, touched at Portsmouth, lay two days, found four Indiamen and a fleet of merchants' vessels ready to sail. I joined their convoy and kept with them till I saw Madeira, when I hauled off for the Westward. I ran down the trades and arrived at Trini- 
dad in thirty-one days. On my arrival I found it hard to obtain information of the Orinoko. I chartered a sloop at $\$ 14$ per day and went up the Macmoro River to Angostura. I then found a plenty of Produce and a sale for goods. I returned to Trinidad and purchased about $\$ 14,000$ worth of goods and attempted to enter my vessel. On obtaining my permit, the collector informed me that my vessel was liable to seizure on account of India goods, ${ }^{1} \$ 12,000$ worth of which I had on board, being prohibited by act of Parliament from coming to entry in an English Colony under a foreign flag. Finding they intended to seize my vessel, I called on Judge Futter and two of the first attorneys, who informed me my vessel was liable and the Governor advised me to be off. I accordingly wrote to London, gave my advice, and chartered a small schooner to take the goods I had bought, and hired a young man as clerk

1 Only English vessels were allowed to carry colonial goods from England to an English colony. 
who spoke Spanish, to come on to the Mackenye and meet me in the Grand River. In the meantime, the Custom House was making arrangements to take possession of my vessel. All my arrangements were made in an hour. A ship lying close by me, which had twenty-five men before the mast, was consigned to $\mathrm{Mr}$. Burley, from whom I took a letter to the mate. He came on board with all his crew. We had all our yards up and sailed immediately, a quick breeze and fair, for the Straits of Boca. On looking toward the harbor we discovered the Deputy Collector and a Launch of soldiers in pursuit, but with a good wind and clear course, we got off and after beating one day off Trinidad we fetched under the lee of Grenada. From there I fetched Causland Bay on Tobego. On standing in, two English ships in the harbor got out springs and presented their broadsides. The Fort was well manned. On coming within gunshot I tacked and set Spanish colors and stood off. 
But they kept making signals. The next day I passed to windward of the Island and standing over the Oronoko we fetched Wyman River and ran down for Cape Bar. We ran up as far as the junction of the Maturin and Grand River and the Macareo. In ten days I found my schooner with my goods. I proceeded to town and discharged my schooner and Brig, and consigned myself to Don Juan Hymont, a German merchant, and commenced selling my cargo and purchasing produce. We lay about four months and laded the Brig and I found myself short of money to pay my duties; consequently, I went to Trinidad and purchased about $\$ 7000$ worth of goods and chartered a sloop to take me back to Angostura. On my passage up the Macareo one night, while at anchor and fast to the bank, I had lain myself on the mainsail of the vessel to avoid mosquitoes. At twelve o'clock at night a discharge of a small cannon and a general shout of "abordo" waked me, when instantane- 
ously one hundred Sambos and Indians were on board. All my crew of the sloop were tied by the hands, and hove into boats. I immediately rose from my place in the sail, when the Commander of the squadron, which was a Patriot squadron, demanded in Spanish, "Who are you?" I replied, "I am an English messenger from the Government of Trinidad to Angostura," when he immediately ordered all his crew in their boats and not to touch the least thing aboard my vessel. 


\section{CHAPTER VI}

CAPTAIN LAMSON'S “Diary” leaves $\checkmark$ him trading on the Orinoco. Of his life during the remainder of the war we know nothing, but it is probable that he traded for a time in Spanish waters and then returned to the Continent. When peace was declared he left England on the "Isabella," ostensibly as a passenger, and arrived in Boston in the spring of $1815 .^{1}$ How he passed the next four years is not known, but some time in 1820 he took command of the brig "Belvidere," 150 tons burden, owned in Beverly, and sailed for New Orleans. ${ }^{2}$

1 “Arrived in Boston Spanish brig 'Isabella,' Peter A. Argevola, master, forty days from Cowes and twenty days from St. Michaels. Captain Z. G. Lamson of Beverly, passenger." - Salem Gazette, May 12, 1815.

2 "Brig 'Belvidere' of Beverly, Lamson, Master, reported at the Balize." - Salem Register, Sept. 13, 1820. 
Captain Lamson remained in command of the "Belvidere" from 1820 to Aug. 25, 1823, when the brig was condemned and sold. In the latter part of 1820 he sailed from New Orleans for Liverpool, thence to Bordeaux, and returned to New Orleans. ${ }^{1}$ The "Louisiana Gazette" of June 4, 1822, advertises, "For Philadelphia. The substantial fast sailing brig 'Belvidere,' Z. G. Lamson, master, will sail in the course of the present week. For freight of the bulk of fifty bales of cotton or passage, apply to the master on board, opposite St. Louis Street, or to Eben Fiske." He reached Philadelphia ${ }^{2}$ in August, and sailed for New Orleans in November, but was obliged to put in leaky at Charleston and repair ship. The next year and a half he spent most of his time trading between Port au Prince and New Orleans. That he was

1 “Brig 'Belvidere,' Lamson, for Bordeaux from Liverpool, Feb. 19." - Columbian Centinel, May 1, 1821.

2 “ Philadelphia, Aug. 2, brig 'Belvidere,' Lamson, thirty-nine days from New Orleans." - New York Evening Post, Aug. 3, 1822. 
unfortunate as usual, the following clippings from the Salem papers show:-

"Salem Gazette," March 30, 1821 : "Brig 'Belvidere,' Z. G. Lamson of Beverly, Master, which sailed from the Balize Dec. 4, arrived in Crook harbor much shattered." "Salem Register," July, 1822 : "Brig 'Belvidere' was discharging at the Balize, June 17, 1822, in consequence of damage received June 15 by a log on the way down the river."

"Salem Register," Nov. 27, 1822: "Arrived in Charleston Nov. 15 brig 'Belvidere,' Lamson, master, bound to New Orleans, put in leaky."

"Salem Register," 1822: "A New York paper reports that the brig 'Belvidere,' Lamson, master, has been condemned and sold at Port au Prince."

In addition to these accidents of the sea Captain Lamson had the misfortune to be taken by a piratical vessel and experienced both torture and loss of cargo. Piracy, long rife in the Caribbean Sea, had at this time 
reached its culmination. Towards the close of the War of 1812, Commodore Patterson broke up the famous pirate gang of Jean Lafitte $^{1}$ and drove them from their rendezvous at Barataria, near the mouth of the Mississippi. Lafitte and his men, some eight hundred in number, afterwards joined General Jackson at New Orleans, and fought so bravely against the English that President Madison granted them a pardon Feb. 6, 1815. It is fair to presume, however, that no real change occurred in their moral character, and that most of the men relapsed into piracy. Lafitte, after three years, turned pirate again, and made Galveston Island his headquarters. Several of his vessels were taken by the U.S. cutter "Alabama," and their crews tried and

1 Jean Lafitte was a man of considerable ability. In his early piratical life he claimed to fight only against the Spaniards; but if so, he made many mistakes as to nationality. In 1813 Governor Claiburne of Louisiana offered $\$ 5000$ for his head. He replied by an offer of $\$ 50,000$ for the Governor's. He died in Sisal, Yucatan, in 1826. 
hanged; but he eluded capture, and in 1821 was cruising in the brigantine "Pride," making the Island of Margarita his rendezvous. Lafitte, however, was a man who conducted operations on a large scale, and hardly a type of the ordinary pirate of the Caribbean Sea. Most of the piracy in the West Indies at this time was conducted in large boats or small sloops and schooners of not over seventy tons. These vessels of shallow draught, manned by a motley crew of Spaniards, Portuguese, and negroes, lurked among the numerous keys, and levied toll on passing ships. Although carrying one or two heavy guns, the pirates relied chiefly on boarding, neither expecting nor encountering resistance. ${ }^{1}$ The captured vessel was robbed of its cargo, but life was rarely taken, ${ }^{2}$ not from any conscientious

${ }^{1}$ In looking over the files of the Boston, New York and Salem papers for the years 1820 to 1822 inclusive, the writer found but two cases where organized resistance was made to a piratical attack in the Caribbean Sea.

${ }^{2}$ This was true as a rule, but in quite a number of 
scruples, of course, but merely as a matter of policy. Torture was freely applied to extort possible hidden treasure, and when the vessel was thoroughly sacked the pirates sailed away, leaving the captain free to resume his course. In December, 1819, a memorial $^{1}$ from prominent insurance men of Boston was addressed to President Monroe, calling attention to the repeated acts of piracy in the West Indies, and giving a list of forty-four vessels robbed, copied from one paper in that year.

The "Salem Register" of Jan. 26, 1822,

cases murder, outrage and scuttling of the vessel were perpetrated in true piratical fashion.

${ }^{1}$ In March, 1822, Mr. McLean of Connecticut from the committee on naval affairs presented to Congress an interesting report on suppression of piracy in the West Indies. In consequence it was resolved, "That it is expedient forthwith to fit out and put in service the corvette 'Cayenne,' the sloops of war, 'John Adams,' 'Erie' and 'Peacock' for the protection of commerce and suppression of piracy in the West India seas and Gulf of Mexico and also to employ the frigate 'Constellation,' should the President deem her employment necessary for purposes aforesaid." 
has an article headed "More Piracies! The brig 'Belvidere,' Lamson, on her way from Hayti to New Orleans was boarded Dec. 9, 1821, by a piratical vessel of one gun and fourteen men, one American and the rest Spanish and Portuguese. The crew were confined in the forecastle, and the officers, passengers, and men plundered of everything of value the villains could find and some of the cargo. After hanging the captain and mate up to the main yard until life was nearly extinct to extort more money from them, they departed."

The "Salem Register" of Feb. "2, 1822, gives further particulars of this outrage: "Captain Lamson, brig 'Belvidere,' has published an account in a New Orleans paper of his treatment from the crew of a pirate schooner of about forty tons off Key Sarenal. They took tobacco and coffee enough to load their vessel. Captain Lamson concludes as follows: 'After being in the forecastle eighteen hours they called up myself and passengers, and to complete 
their rascality they rove a yard rope and hung us up separately, taking the precaution to secure us one by one as they finished their proceedings. Monday at 6 A. M. they came on board again, cut our cable, and run us in between two reefs, two leagues to the westward of Neuvitas, taking with them my small cable, anchor, kedge, hawser, and all the spare rigging aboard."

Up to this time, either from economy, fear, or indifference, American merchants had neglected to provide their vessels with arms, and robbery on the high seas had become both lucrative and safe. Captain Lamson, however, had been hanged once, and had no intention of trusting his head in the noose a second time. When he next sailed from New Orleans, some thirty days after his capture by the pirates, he went armed. His armament was not heavy, consisting of one 24-pound carronade, one brass 3-pounder, four muskets and seven pistols. The voyage to Port au Prince was uneventful, but on his return trip at 
the channel of Caye de Sucre, near the coast of Cuba, he spoke the U. S. schooner "Alligator." This vessel, together with the "Shark" and "Grampus," had been detailed by the government to cruise in the Caribbean Sea and Gulf of Mexico to put a stop to the piracies which threatened to ruin American trade in those waters. Captain Lamson boarded the "Alligator," and learned from her captain the particulars of an engagement which that vessel and the "Grampus" had sustained with several piratical vessels the day before, and had the pleasure of watching from the deck of the "Alligator" the chase of another pirate by Captain Stockton in the tender, "Jane." Although Captain Lamson, in that part of the log of the "Belvidere" which we quote, narrates what he saw and heard on this occasion, still the account of these same events given in the "Charleston City Gazette and Commercial Daily Advertiser" of May 21, 1822, is so much more comprehensive that we give it in full. "The 
evening on which the 'Alligator' left Xibara and was on her way to Neuvitas, the place designated as a rendezvous for her tender and boats, she fell in with the U. S. schooner 'Grampus,' Lieut. Commander Gregory, and after some communication united their forces and proceeded to Neuvitas, where Captain Stockton found his tender and was informed that she had been plundered by a pirate, without the resistance of a single shot. This insult Captains Stockton and Gregory resolved to avenge, and to atone for the loss not only of victory but some honor, determined to fit out the schooner 'Jane' as a new tender, and Captain Stockton took command himself, while Captain Gregory followed with the 'Alligator' and 'Grampus.' The little squadron was to rendezvous at a place called Sugar Key. The particulars of the expedition will be furnished hereafter. Among the results Captain Stockton recaptured an English brig which was in possession of four piratical vessels, having 
among them about two hundred men. The pirates were in sight at the time of recapture. The mate of the English brig made a narrow escape, having actually a halter round his neck and just suspended at the moment of deliverance. The pirates were pursued. The cunning dogs whenever the 'Jane' was near them, and out of sight of her aids, would draw up in line of battle, but would not wait for the broadside. Captain Stockton was at one moment so near as to receive fifteen or twenty shots from their long 12-pounder, but unfortunately the shallowness of the water prevented his coming into closer contact. In his eagerness to pursue, the 'Jane' was once run on shore, and he could only give a prompt return from his 6-pounder, at which the rogues laughed! Notwithstanding their lightness and knowledge of the coast the result of this chase was the capture of one of their schooners with a full cargo taken from the English brig, the burning of another and the running on shore of a third. 
The fourth effected her escape with the boats and crews of the others. Not a man was captured. However this is to be regretted, the officers of the 'Alligator' had the satisfaction of burning the vessel that plundered their tender. The captured schooner was sent into Havana and the 'Alligator' has brought into Charleston her other prizes, a Columbian armed schooner called the 'Cienega,' whose crew had mutinied at Reggia Island, and a sloop found at sea with no living creature aboard but a dog."

Fortunately we are enabled to give Captain Lamson's own account of these occurrences, as well as other matters of interest, from fragments of the log of the "Belvidere," published in the "Columbian Centinel" of June 26, 1822, the "Courier de Louisiana" of May 20, 1822, and the "Salem Gazette" of June 25, 1822.

Extracts from log of brig "Belvidere," Lamson, master: "May 2, we spoke the United States schooner 'Alligator,' Cap- 
tain Stockton, at the channel of Caye de Sucre, coast of Cuba, and was informed on board that he had recaptured an English brig, of which the captain and mate had been hung by the pirates. The 'Alligator' had also retaken the Columbian schooner 'Cienega,' which had been seized by a mutinous crew. At the time of leaving, Captain Stockton was in shore with a schooner of light draught, with seventy men belonging to the 'Alligator' and 'Grampus,' together with the three crews of the prizes he had taken. He engaged a pirate launch of seventy men, but as he was much embarrassed by all those he had aboard, he was in doubt what to do with them. The famous Lafitte was among the pirates. The very day of our parting we fell in with a schooner and three launches which gave chase, but blowing heavy and being to windward, succeeded in getting from them. The next day at 10 A. M. made a schooner on our larboard bow, lying under mainsail and jib. At 11 A. M. she was on our lee 
quarter and fired a gun, coming up fast. At twenty minutes past eleven fired a second shot and hoisted a red flag with death's head and a cross under it. Finding $I$ had a hard character to deal with I prepared for him as well as I was able, and immediately brailed up my top sails, hauled up my courses, clewed down top gallant sails, hauled down the jib, braced in the mizzen top sail, and kept off two points. I then fired a musket and hoisted colors. At $12 \mathrm{~A}$. M. she came alongside within two yards distance. Hailed with 'God damn you, send your boat aboard. I will murder all hands of you.' He had not discovered our gun at that time. I told him I would send her directly. He gave me a whole volley of musketry and blunderbusses before I had answered him. Our gun was pointed and cloth removed, and we commenced as smart a fire as possible with one 24pound carronade, four muskets, and seven pistols. At our first fire six of them were seen to fall, among them the Captain or 
leader, being the one who hailed me. He only discharged his large gun three times alongside, as our third shot broke his carriage and his gun fell into the lee seuppers. He then kept up as smart a fire with muskets and blunderbusses and dropped near the stern, expecting to find more comfortable quarters, but he there got a most terrible cutting up from a brass 3-pounder, by which he was raked within twenty yards distance with a round shot and two bags of forty musket balls each, which completely fixed him. His vessel holding such a wind and going so fast she soon was clear of grape shot range and wore ship. I did not receive any more fire from him or even hear a word spoken on board of him, and in fact did not see any one on deck. Our loss was one man killed, shot through the head, about forty musket balls through the rudder case, tiller, skylight, and companion way, our foretopsail halliards shot and our trysail halliards cut in three places. We counted twenty-two men when 
she came alongside. He had a brass five or nine pounder amidships and muskets and blunderbusses and plenty of them. -Z. G. Lamson."

The day after the encounter with the piratical vessel, Captain Lamson fell in with a Boston ship commanded by Captain Baker, and gave him an account of the affair. "Boston Palladium," May 21, 1822: "Captain Baker from Honduras spoke May 4, Key Sal twenty leagues. southeast, brig 'Belvidere,' Lamson, of Beverly, from Port au Prince to New Orleans, and was supplied with a barrel of flour. Captain Lamson communicated the following information: thirty hours before he had an action with a pirate of about sixty tons, full of men. That two hours before he was boarded by the United States vessel 'Alligator,' who had two captured pirates in her company, and that another vessel of war was then in pursuit of a large schooner supposed to be a pirate, she having three launches in tow. Captain 
Lamson's brig was much cut up by musketry, but no round shot struck her hull. Had none wounded, and but one man killed. Captain Lamson was considerably burned in the face by an explosion of gunpowder. He had only thirteen men."

On his arrival at New Orleans Captain Lamson was received with great enthusiasm. One of the papers, after giving an account of the affair, concludes as follows: "Captain Lamson is certainly entitled to great praise from all for his gallant and spirited conduct. A few such checks as this would as effectively prevent a repetition of the outrages perpetrated by these lawless sea monsters as anything which our seventy-fours or frigates could do."

The "Louisiana State Insurance Co.," as a mark of appreciation, presented Captain Lamson with a silver service of four pieces, inscribed, "Presented by the Louisiana State Insurance Co. to Captain Z. G. Lamson of the brig 'Belvidere' of Beverly for gallantly repelling a Piratical vessel on 
the third of May, 1822." The records of the meeting at which the service was voted, together with the report of the committee and the letters of presentation to and acceptance from Captain Lamson, copied from the "Asylum and Feliciana Advertiser" of June 19, 1822, are given below:-

\section{Tribute to Valor.}

The President and directors of the Louisiana State Insurance Co. have voted a piece of plate to the value of three hundred dollars to Captain Lamson of the brig "Belvidere" and two hundred in cash to his crew for their gallant defence of their vessel against the attack of a piratical cruiser on the third ult. off Key Sal. We annex a copy of the proceedings of the board and of the correspondence between the President of the company and Captain Lamson.

Louisiana State Insurance Co. June 7, 1822.

The report of the Committee appointed 
to inquire into the circumstances in relation to an action between the brig "Belvidere," Captain Lamson of Beverly and a piratical vessel on the passage of the former vessel from Port au Prince to this place, having been read, was unanimously adopted, and on motion it was resolved that the President and directors of the Louisiana State Insurance Co. do testify their high sense of obligation for the service rendered them by Captain Lamson of the brig "Belvidere" in repelling the attack made on his vessel by a piratical cruiser on the third day of May last, on her passage from Port au Prince to this place, by which a considerable amount of property was saved to this institution, do order that the President be directed to return to Captain Lamson the thanks of this board for his exertions on this occasion, and that a piece of plate of the value of three hundred dollars be caused to be executed under the superintendence of a committee of this board and presented to Captain Lamson 
in the name of this company and likewise the sum of two hundred dollars be appropriated and placed at the disposal of Captain Lamson to be distributed among his crew in such proportions as he may conceive their services merit.

E. Ceflecher, Sec.

Louisiana State Insurance Offices.

New Orleans, June 8, 1822.

Sir, - I am directed by a vote of this board, a copy of which is enclosed, to return you the thanks of the company for the signal service rendered them by your successful exertions in repelling the attack of a piratical cruiser on the brig "Belvidere," the cargo of which was insured in this office; and it affords me much pleasure to have an opportunity individually of expressing to yourself and to your crew the gratification I derive from the gallant conduct displayed on the occasion which you will please to communicate to them in distributing the amount voted to their benefit, which you will find enclosed. With the 
best wishes of your future success and happiness, I am very respectfully your obedient servant,

\section{R. RELF,}

Pres. Louisiana Insurance Company.

To the President and Directors of Louistana State Insurance Co.

Gentlemen, - I received yours of the eighth instant enclosing resolution of the board of directors as well as the thanks to myself and crew for the defence made on board the brig "Belvidere" of Beverly under my command off Key Sal against a piratical cruiser. Gentlemen, I have to tender my best respects as well as those of my crew, for the marked attention with which you have honored us, and have to say under similar circumstances we shall ever be ready to defend ourselves against those pests of the ocean. The gratuity for the benefit of my crew has been distributed agreeably to your instruction, with which they are highly gratified.

Accept, Gentlemen, my best wishes. Z. G. Lamson. 
The brig "Belvidere" was condemned Aug. 25, 1823, and Captain Lamson probably returned to his family in Beverly. In July of 1824 he sailed for Honduras as supercargo on board the schooner "Franklin" of Boston, and was wrecked on the "Blue Caicos." The crew of the "Franklin" were saved by another vessel. The "Salem Register" of Oct. 14, 1824, has this item: "Schooner Potosi arrived in Boston from Spanish Main and St. Isabelle, Lamson, master. One Beverly man died at sea." Whether the Lamson mentioned was Z. G. Lamson the writer is ignorant. If so, it is probable that he merely brought the vessel home. About this time, or a little later, he established himself as a merchant in Granada, Central America, trading on his own account, and also buying and selling on commission. Oct. 20, 1834, he writes to his family that he has just recovered from a malignant fever which had lasted forty days, but he hopes soon to be able to resume work. Nov. 8,1838 , he 
entered into the following agreement with the firm of John H. Howland, Son and Co. of New York. "John H. Howland, Son and Co. having made a shipment on board the brig 'Galen,' bound for St. Juan, C. A., and consigned the same to me, I hereby agree to dispose of the said goods to the best possible advantage for their interest, and invest the same in hides, indigo, or other produce, and ship the same to their consignment. And it is further understood between the parties that as a remuneration for transacting said business in Central America, that I am to receive, after deducting interest, freight, insurance, commission, and guarantee, and other incidental charges on the sales of returns at this port, one third of the net profits.

Z. G. Lamson."

Captain Lamson continued his relations with the firm of John H. Howland, Son and Co. up to or near the time of his death. The Howlands employed three brigs in the trade, the "Galen," the "Frances," 
and the "Wakefield," shipping to St. Juan checked muslin ginghams of different colors, and taking back to New York indigo and hides. In 1841 trade, which up to that time had been good, became very dull. The Howlands write in March to Captain Lamson that the blockade of Buenos Ayres has been discontinued and hides are going down, also the price of indigo is falling. Captain Lamson in October of the same year writes a long letter to his family in rather a gloomy strain. The brig "Galen," consigned to him, had been seized by the authorities because a few goods did not appear on the manifest, and he had been obliged to appeal to the United States and request their intervention. He had written two letters to Mr. Webster in Washington, and hoped a man-of-war would be sent. Business in St. Juan was very bad, and the merchants all losing money. He had eight thousand pounds of indigo and ten thousand dollars' worth of goods with five thousand dollars due him, but no cash. 
Tied up as he was, it would be at least a year before he could realize and leave the country. He writes of the efforts which his friends at this time were making to have him appointed consul at St. Juan, but expects that they will be unsuccessful. Evidently he kept up his interest in home politics, for he writes: "Mr. Webster's popularity with his friends is as Timothy Pickering's was with the Essex Junto, he is governed in a manner by the Boston and New York aristocrats. Mr. Webster is as ambitious as any man we have. He is an aristocrat at heart, though a better man I believe we could not at the present moment have as Secretary of State, but neither he nor Clay will ever be President." It is easy to see from this letter that his many disappointments were beginning to tell on Captain Lamson. His optimism has disappeared, and the best he hopes for is to realize on the wrecks of his fortune and return to Beverly. Although some years later he did revisit his family, his pecuniary entangle- 
ments in Granada compelled his return to that country, and he died there Dec. 16, 1846 , in the delirium of fever. 
(che libergito pregly

CAMBRIDGE - MASSACHUSETTS

$\mathbf{U} \cdot \mathbf{S} \cdot \mathbf{A}$ 

